\title{
WestVirginiaUniversity
}

THE RESEARCH REPOSITORY @ WVU

Graduate Theses, Dissertations, and Problem Reports

2021

\section{A Selective Study on Chinese Art Songs after 1950}

Gehui Zhu

gz0009@mix.wvu.edu

Follow this and additional works at: https://researchrepository.wvu.edu/etd

Part of the Music Performance Commons

\section{Recommended Citation}

Zhu, Gehui, "A Selective Study on Chinese Art Songs after 1950" (2021). Graduate Theses, Dissertations, and Problem Reports. 8287.

https://researchrepository.wvu.edu/etd/8287

This Dissertation is protected by copyright and/or related rights. It has been brought to you by the The Research Repository @ WVU with permission from the rights-holder(s). You are free to use this Dissertation in any way that is permitted by the copyright and related rights legislation that applies to your use. For other uses you must obtain permission from the rights-holder(s) directly, unless additional rights are indicated by a Creative Commons license in the record and/ or on the work itself. This Dissertation has been accepted for inclusion in WVU Graduate Theses, Dissertations, and Problem Reports collection by an authorized administrator of The Research Repository @ WVU.

For more information, please contact researchrepository@mail.wvu.edu. 


\title{
A Selective Study on Chinese Art Songs after 1950
}

\author{
Gehui Zhu
}

\author{
A Doctoral Research Project \\ Submitted to College of Creative Arts at \\ West Virginia University
}

in partial fulfillment of the requirements for the degree of

Doctor of Musical Arts

in

Voice Performance
Hope Koehler, D.M.A, Committee Chair and Research Adviser William Koehler, D.M.A Matthew Heap, Ph.D. Victor Chow, Ph.D.

\author{
School of Music \\ Morgantown, West Virginia \\ 2021
}

Keywords: Chinese Art Songs after 1950, Contemporary Chinese Art Songs, Chinese Poems, Chinese Art Songs for Classical Singers.

Copyright 2021 Gehui Zhu 


\section{ABSTRACT \\ A Selective Study on Chinese Art Songs after 1950}

Gehui Zhu

The purpose of this paper is to provide an insightful study of Chinese art songs after 1950. A number of works have been written in English about the repertoire of Chinese art songs, but most of these studies concentrated on songs written before 1950. It is difficult for English speakers to find and study Chinese art songs after 1950. In fact, they have largely been ignored. However, these songs have significant pedagogical and aesthetic values. This study aims to provide musicians and voice teachers a handy and practical tool to study and sing Chinese art songs composed after 1950.

This research begins with an overview of Chinese art songs and their historical background, followed by a literature review. The main body of this study will provide an analysis of forty-two Chinese art songs composed by nine different Chinese composers. Several factors will be analyzed, including range, tessitura, tempo, piano accompaniment, difficulty level, voice type, voice characteristics, and translations.

As a unique and relatively new genre for Western musicians, Chinese art songs are worthy of attention for both educational and aesthetic reasons. They are unique in that they combine Western compositional techniques with Chinese five-tone systems. Listening and learning Chinese art songs will provide musicians with a refreshing and new perspective. Texts of Chinese art songs are selected from poems written in either classical or vernacular Chinese. The poetry and the language are deeply rooted in Chinese culture. Among the many benefits of learning these poems is gaining insight into China's social, historical, and political context of their time. This study will provide a valuable resource for Western scholars to learn about Chinese culture and Chinese history from a musical perspective. 


\section{ACKNOWLEDGEMENTS}

I would first like to thank my committee chair and my voice teacher Dr. Hope Koehler. Dr. Hope Koehler is passionate, knowledgeable, and wise. Over the past three years, I have learned much more than just academics. Her persistence and her encouragement helped me during many difficult times. I would like to express my deepest appreciation for her support of me during my studies at West Virginia University.

I would also like to extend my deepest gratitude to all my committee members, Dr. William Koehler, Dr. Matthew Heap, and Dr. Victor Chow. Thank you for your patience, support, and help. My success would not have been possible without your guidance!

Finally, I would like to express my heartfelt thanks to my family and my friends. Thank you for always being there for me and your unconditional support over the years! 


\section{TABLE OF CONTENTS}

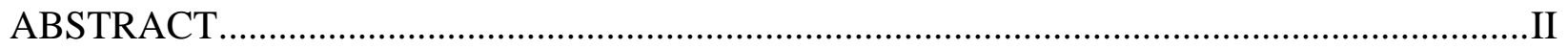

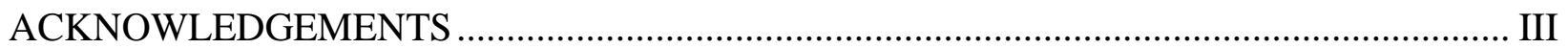

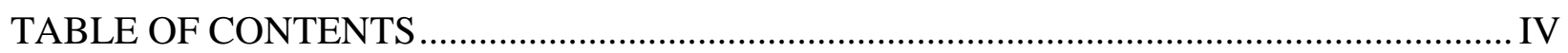

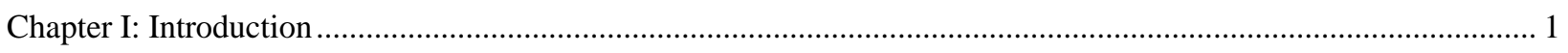

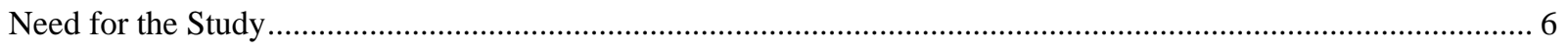

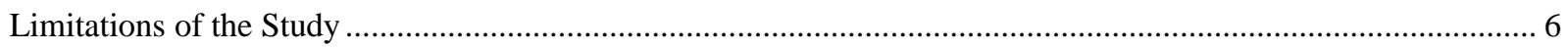

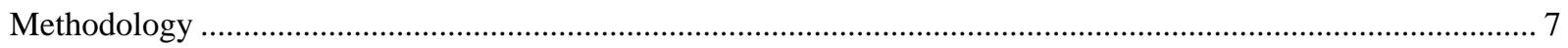

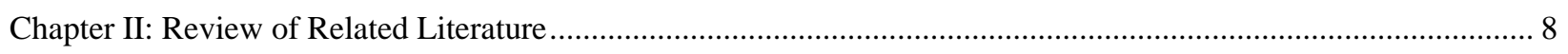

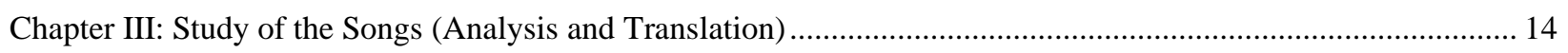

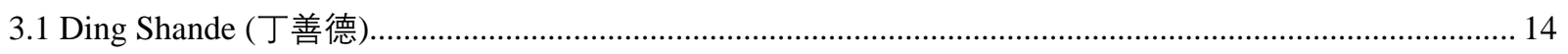

3.1.1 Tai Yang Chu Lai Xi Yang Yang (The Rise of the Sun Brings us Hope and Happiness ) ................. 15

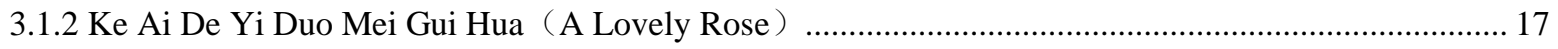

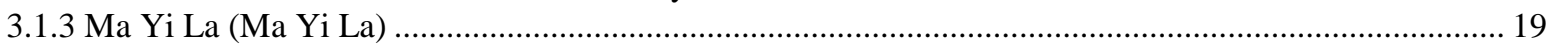

3.1.4 Huai Hua Ji Shi Kai (When the Sophora Will Blossom) ……............................................................ 21

3.1.5 Ai Ren Song Wo Xiang Ri Kui (My Lover Sent Me Sunflowers) .......................................................... 23

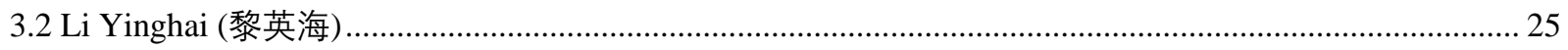

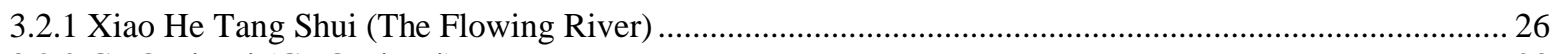

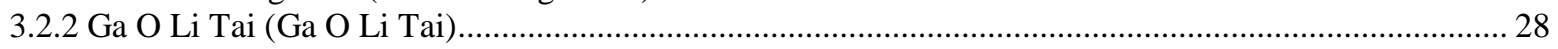

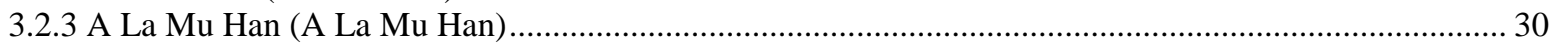

3.2.3 Zai Yin Se De Yue Guang Xia (Under the Silver Moonlight) ................................................................ 32

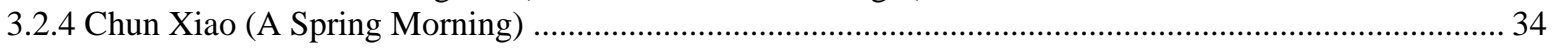

3.2.5 Feng Qiao Ye Bo (Mooring by the Maple Bridge at Night) ................................................................... 36

3.2.6 Deng Guan Que Lou (On the Stork Tower) ……............................................................................. 38

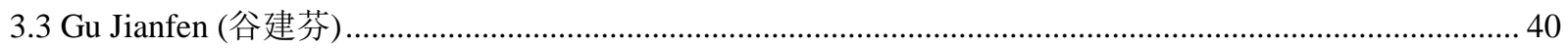

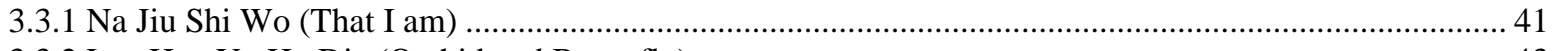

3.3.2 Lan Hua Yu Hu Die (Orchid and Butterfly) .................................................................................... 43

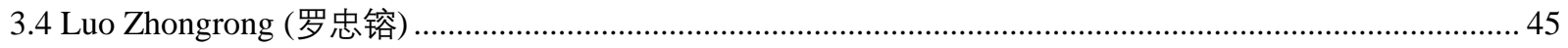

3.4.1 She Jiang Cai Fu Rong (Crossing the River to pick Hibiscus).............................................................. 46

3.4.2 E Mei Shan Yue Ge (Song for the Moon over Mountain E Mei) .......................................................... 48

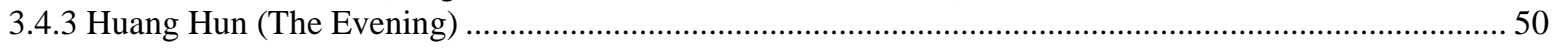

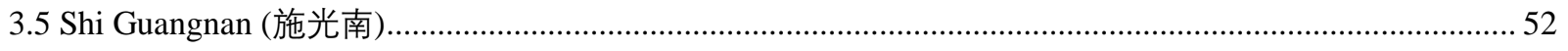

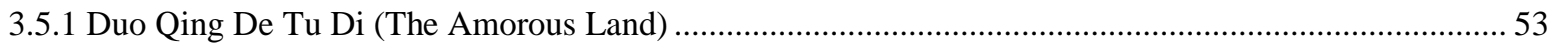

3.5.2 Shui Ku Ye Ge (The Melody in the Reservoir at Night) .................................................................... 55

3.5.3 Zai Xi Wang De Tian Ye Shang (On the Fields of Hope) ..................................................................... 57

3.5.4 Zhu Jiu Ge (A Drinking Song) ............................................................................................... 59 
3.5.5 Wo De Zu Guo Ma Ma (My Home Country, My Mama)

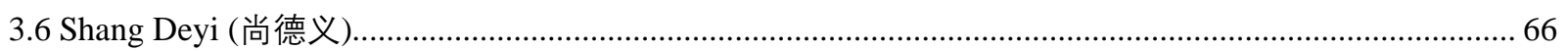

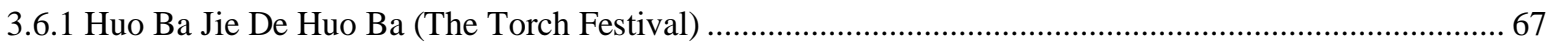

3.6.2 Ba Li Sheng Mu Yuan De Qiao Zhong Ren (The Bellringer at Notre-Dame de Paris) ......................... 69

3.6.3 Chun Feng Yuan Wu Qu (The Spring Ballade) ........................................................................... 71

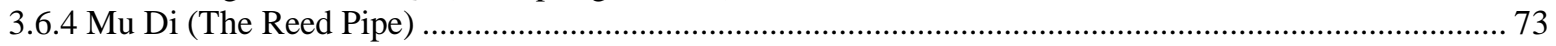

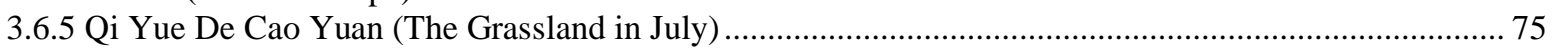

3.6.6 Zu Guo Yong Zai Wo Xin Zhong (My Home Country is Always in My Heart) ..................................... 77

3.6.7 Lao Shi, Wo Zong Shi Xiang Qi Ni (My Teacher, I Always Miss You) .................................................. 79

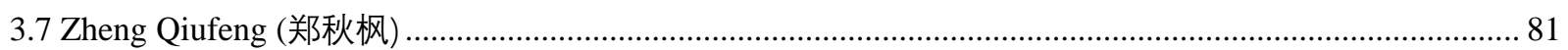

3.7.1 Chun-Zu Guo De Chun Tian (Spring-My Country's Spring) ............................................................. 82

3.7.2 Qiu-Pa Mi Er, Wo De Jia Xiang Duo Me Mei (Autumn-Pamirs, How Beautiful My Hometown is) ...... 84

3.7.3 Wo Ai Mei Yuan Mei (The Lovely Wintersweet in Mei Garden) ………….......................................... 86

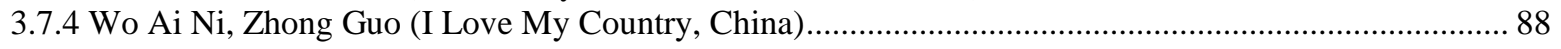

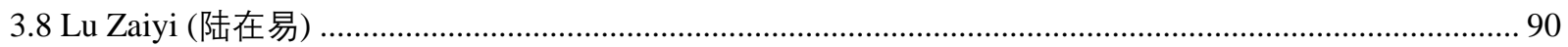

3.8.1 Zu Guo-Ci Xiang De Mu Qin (My Country, My Kind Mom) .............................................................. 91

3.8.2 Cai Yun Yu Xian Hua (The Colorful Clouds and Flowers) ................................................................... 93

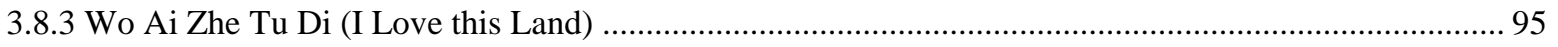

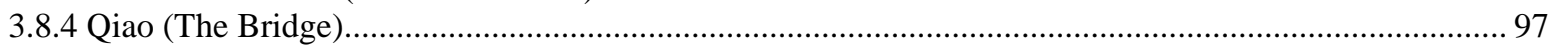

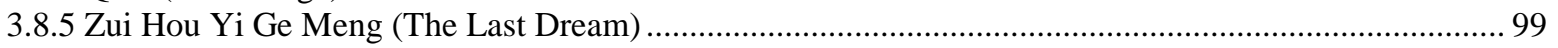

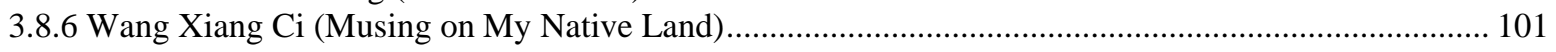

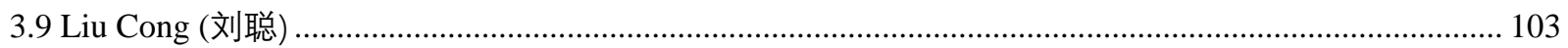

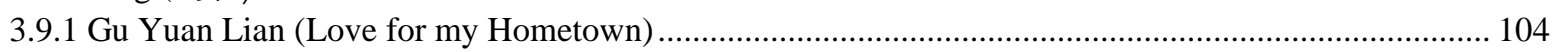

3.9.2 Niao Er Zai Feng Zhong Ge Chang (The Bird is Singing in the Wind) .............................................. 106

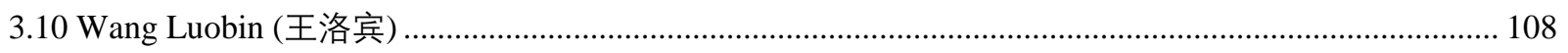

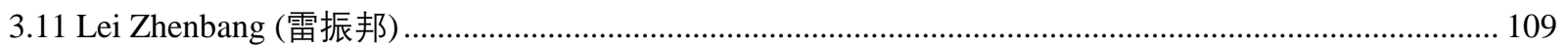

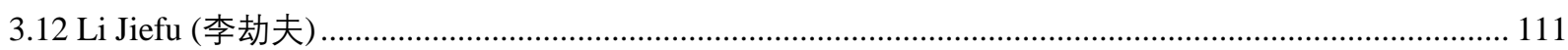

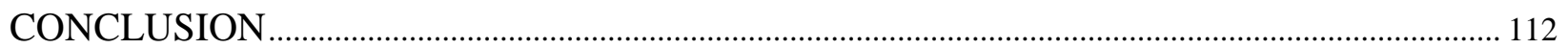

APPENDIX I: LIST OF THE ART SONGS IN ALPHABETIC ORDER ….................................... 114

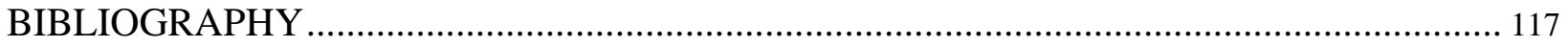




\section{Chapter I: Introduction}

The first generation of Chinese art songs appeared in the 1920s. This was a time when China was going through radical political, cultural, and social changes. On May 4th, 1919, about three thousand students from different colleges and universities in Beijing gathered to protest the decision made by the Treaty of Versailles, which allowed Japan to continue controlling Shandong Province. Protests then spread across the country rapidly. People from different social and political areas acted and participated in this movement. ${ }^{1}$ It was known as the New Cultural Movement (also known as the May Fourth Movement), which marked a turning point in modern Chinese history. It was influential in terms of bringing a political and cultural shift from the traditional hierarchy of obedience to Western ideas of equality and democracy. ${ }^{2}$ One of the most important aspects of the movement was the reform of language. Up until this time, poetry was written in Classical or Literary Chinese, which was a complex and difficult literary language that only scholars could read. ${ }^{3}$ The scholars and intellectuals, especially those who studied abroad, initiated a new way of writing. They wrote in the vernacular language which common people could understand. This gave the birth to modern Chinese poetry. Influential poets included $\mathrm{Hu}$ Shi (1891-1962), Guo Moruo (1949-1978), Xu Zhimo (1897-1931), and Cai Yuanpei (18681940). An increasing number of modern Chinese poetries appeared in magazines and publications. This new world of literature laid the foundation for the birth of Chinese art song. Chinese composers who studied abroad returned home to join this new trend. These composers

\footnotetext{
${ }^{1}$ R. Keith Schoppa, Twentieth Century China: A History in Documents (Oxford: Oxford University Press, 2010): 46

${ }^{2} \mathrm{Mu}$ Liu, "The discussion about the nature of the wusi movement" [in Chinese], Zhexue yanjiu 2(1963): 77.

${ }^{3}$ R. Keith Schoppa, Twentieth Century China: A History in Documents (Oxford: Oxford University Press, 2010): 46.
} 
included Qing Zhu (1893-1959), Xiao Youmei (1884-1940), Huang Zi (1904-1938), and Zhao Yuanren (1892-1982). They combined Western composition techniques with modern Chinese poetry and created the first generation of Chinese art songs. From 1920 to the 2nd Sino-Japanese war (1931-1945), the main themes of Chinese art songs during this period included personal feelings, society, freedom, nature, and humanity. " ${ }^{4} \mathrm{Da}$ Jiang Dong Qu" (The River Flowing to the East, 1920) was known as the first Chinese art song. It was composed by Qing Zhu when he was studying in Japan. Later on, Xiao Youmei, who founded the first conservatory in China, made a significant contribution to China's music education. His art songs expressed his feelings toward the war and the society. One of his most famous songs was "Wen" (Question, 1922). The most influential composer during this period was Zhao Yuanren. Composing more than 100 songs in his life, he established the ethnic development of Chinese art songs. ${ }^{5}$ In addition, he gave much useful advice to singers who were singing Chinese songs using Bel Canto technique.

In the 30s and 40s, China was hugely impacted by the 2nd Sino-Japanese War. On September 18th, 1931, Japan invaded Manchuria in the northern region of China. Many scholars and intellectuals started the Anti-Japanese movement. The composers during this period started writing songs to call on people to fight with the invaders and express hope for final victory. The main theme for different types of music during this period was Anti-Japanese. Among those genres, art song was the most representative form because of its text. The composers use art songs to describe their hometown, the warriors, and the determination for the victory. The most influential art song composers include Liu Xue'an (1905-1985), Nie Er (1912-1935), and He Lvting (1903-1999). Nie Er composed "Yi Yong Jun Jing Xing Qu" (March of the volunteer) for

\footnotetext{
4 TingTing Chang, “A Survey of Selected Classical Chinese Art Songs for Solo Voice and Piano," (DMA diss., West Virginia University, 2020), 3, ProQuest (28071684).

${ }^{5}$ Ibid.
} 
calling people to fight for the country since his country was going through the most of difficult times. In 1949, “Yi Yong Jun Jing Xing Qu” was selected as China’s anthem after the establishment of the People's Republic of China. He Lvting's “Ja Ling Jiang Shang” (On the Jialing River) depicted his hometown being destroyed by the invaders and the death of his family. The subject of his song expressed his determination to fight against the invaders.

In 1949, the establishment of the People's Republic of China (PRC) marked the ending of WWII and the civil war. The relatively stable and peaceful environment provides the fertile soil for the development of art songs. From 1949 to the beginning of the Cultural Revolution (1967), most of the art songs fall into two categories. The first was rearranging folk songs from different regions in China to art songs. Ding Shande (1911-1995) was a representative composer. His work "Huai Hua Ji Shi Kai" (When will the Sephora Bloom?) was arranged from a folk song in the countryside of Sichuan province. Another category was setting Mao Ze Dong's poems to art songs. Li Jiefu (1913-1976), who was the dean of Shen Yang Conservatory, wrote 57 art songs based on Mao's poems. Other than the two categories, the art songs during this period included some theme of describing the beauty of nature and hometown, as well love. ${ }^{6}$ Representative works included Mei Li Qi Ge’s “Cao Yuan Shang Sheng Qi Bu Luo de Tai Yang” (The Rising Sun on the Grassland), Lei Zhenbang's "Hua Er Wei Shen Me Zhe Yang Hong” (Why the Flowers are so Red), Tian Ge's “Zao Yuan Zhi Ye” (The night on the Grassland), and "Bian Jiang Chu Chu Sai Jiang Nan" (The Borderland is as Beautiful as the South of Yangtze River). More conservatories were established from north to south and more musicians started to magnify the importance of Chinese art song. This was a time when the Chinese art song became more appreciated by common people.

\footnotetext{
${ }^{6}$ Xinming Sun, “A Discussion of the Development and Features of Chinese Art Song,” [in Chinese] (Master's thesis, GuangXi University, 2015), 15.
} 
In August 1966, China's communist leader Mao Ze Dong proclaimed a shutdown of the nation's schools and started the Cultural Revolution (1966-1976). The target was the right-wing group supported by the Nationalist Party, as well as the ideas of capitalism. Mao opposed the Western capitalist ideology which emphasizes personal feelings and freedom. Since intellectuals and scholars were at the top of the social hierarchy in China, most of them had studied in the Western world and represented different ideological viewpoints, and they were particularly targeted. ${ }^{7}$ Art songs, which aimed at expressing personal feelings, were forbidden during the Cultural Revolution. Some of the great art songs composed before 1976, as well as the composers and singers, were also criticized and punished. The coloratura song for soprano "Kuai Le De Bai Ling Niao" (The Happy Lark) composed in 1959 by He Lvting was famous and popular before 1976. The text of the song describes the beautiful landscape of the country. During the Cultural Revolution, it was criticized as “disintegrating people's revolutionary fighting spirit and turn the art area to a hotbed for restoration of capitalism." 8 He Lvting and the singer Zhou Xiaoyan were punished because of this song. All the love songs during this period were considered to "promote the capitalist philosophy of love" and "seduce the youth to fight for love other than for our country or revolution." 9 During this period, art was considered a political tool to serve the Cultural Revolution. The lyrics of the songs were mostly drawing from Mao's poems or quotations. The melody was straightforward, energetic, and rigid. Lyricism and personal feelings were largely avoided. This situation became better till Premier Zhou Enlai met with musicians and artists in 1970. He promoted that "Revolutionary passion and lyricism should

\footnotetext{
7 Tieyi Zhang, "The first generation of Chinese art song” (D.M.A. diss., University of Iowa, 2019), 4, https://doi.org/10.17077/etd.46dy-8j9t.

${ }^{8}$ Maochun Liang, “A Survey of Art Song During Cultural Revolution” [in Chinese], Journal of the Central Conservatory, no.1 (2008): 32.

${ }^{9}$ Ibid, 32.
} 
be combined; they are not opposite of each other." After this meeting, the composers gradually restored lyricism to their songs, making the characteristic of lyricism deeply displayed in "Zhan Di Xin Ge" (New Songs of the Battlefield). ${ }^{10}$ "Zhan Di Xin Ge" included five song collections published from 1972 to 1976 for political reasons. Each collection started with a quotation from Mao. Several composers' art songs are prominent in these collections, like Jin Fenghao, Zheng Qiufeng, and Shang Deyi. Although these composers adapted to the political needs of the Cultural Revolution, they worked hard to maintain the beauty of the art songs. "You Tian de Zao Chen" (Morning on the Oilfield, 1975) composed by Shang Deyi was a representative work from this time. The text of the song showed the vigorous development of the country's petroleum industry. Shang creatively drew from the folk melody in the Northeastern region in China and used the coloratura part to display the rapid growth of the petroleum industry. ${ }^{11}$

After the Cultural Revolution, composers were gradually allowed to have more freedom in their works. ${ }^{12}$ In the 80s, because of China's economic reform in 1978 and the reopening of conservatories and music schools, Chinese art songs embraced a whole new world. During this period, the composers worked in different ways to establish their personal styles. Examples include composers like Luo Zhongrong (1924-present), whose "She Jiang Cai Fu Rong" (Crossing the River to Pick Hibiscus) was the first Chinese song to use the twelve-tone technique. He creatively expressed an artistic conception by combining the twelve-tone and Chinese pentatonic scales with Classical Chinese language. Other representative composers included Shi Guangnan (1940-1990), Shang Deyi (1932-2020), Zheng Qiufeng (1931-present),

\footnotetext{
${ }^{10}$ Yuchen Zhou, "An Analysis of the Artistic Features in the Song Collection 'Zhan Di Xin Ge' during Cultural Revolution" [in Chinese], Huang He Zhi Sheng no. 17 (2020): 45.

${ }^{11}$ Maochun Liang, "A Survey of Art Song During Cultural Revolution" [in Chinese], Journal of the Central Conservatory, no.1 (2008):34.

${ }^{12}$ Xinming Sun, "A Discussion of the Development and Features of Chinese Art Song" [in Chinese], (Master's thesis, GuangXi University, 2015), 1.
} 
and Gu Jianfen (1935-present). In the last decades of the 20th century, the composition of Chinese art songs became more mature. Conservatories and music schools started to have more voice recitals and national vocal competitions were held yearly. Musicians from the Western world traveled to China to give recitals. With more and more communication across the country and with the outside world, Chinese art song was appreciated by a wider audience.

\section{Need for the Study}

Art song for China was a foreign genre of vocal music. It was introduced in China in the early 20th century. After a century of development, it has become an important part of Chinese vocal music. Chinese composers were not copying Western composition techniques but were combining Western compositional techniques with the Chinese five core tones system ${ }^{13}$, minority ethnic music rhythms, and Chinese opera. ${ }^{14}$ Chinese art songs are deeply rooted in Chinese culture. Thus, learning this repertoire provides a great tool for foreigners to study Chinese culture and music.

There are several dissertations about 20th century Chinese art songs in English, but most of them focus on the first half of the century. It is extremely hard for American voice teachers and students to find the introduction of the repertoire after 1950. Therefore, further study is necessary regarding this topic.

\section{Limitations of the Study}

This dissertation will be limited to a discussion of 20th century Chinese art songs after 1950. It will exclude opera arias and chamber music. Since the development of music and art in

\footnotetext{
${ }^{13}$ Each tone has a name for it: Gong (宫), Shang (商), Jue (角), Zi (徽), Yu (羽). They are often connected with five elements: earth, wood, metal, fire, and water.

${ }^{14}$ Xinming Sun, "A Discussion of the Development and Features of Chinese Art Song" [in Chinese], (Master's thesis, GuangXi University, 2015), 1.
} 
Taiwan, Hong Kong, and Macao are different from mainland China, this study will only include composers from mainland China. There are already a considerable number of dissertations, articles, and books about Chinese diction and phonetic system, so discussion about this area will be excluded. The purpose of this study is to provide an analysis of selected repertoire after 1950. It would be extremely labor intensive to include all the composers and their works since many examinations and translations would have to be done for each piece. I have chosen nine representative composers for this study, including Ding Shande, Li Haiying, Gu Jianfen, Luo Zhongrong, Shi Guangnan, Shang Deyi, Zheng Qiufeng, Lu Zaiyi, and Liu Cong. Their works display the most charming developments in Chinese art songs, and they are often studied and sung in today's conservatories and vocal competitions. Wang Luobin, Lei Zhenbang, and Li Jiefu are three composers who have written a large number of songs without the piano accompaniment, but the melodies in their works have always been an inspiration for later composers. Their works won't be discussed in this study, but their careers will be presented briefly at the end of this study.

Hanyu Pinyin is a special system for helping people to spell out the Chinese characters. It is very helpful for non-Chinese speakers to learn speaking Mandarin. I will include Hanyu Pinyin for the first three songs in this study as a reference. For other songs, the online website (xh.5156edu.com) and the dictionary Xinhua Zidian (Xinhua Dictionary) are helpful tools for finding Hanyu Pinyin of the Chinese characters.

\section{Methodology}

This study will begin with a historical background and introduction of Chinese art songs. The following chapter will discuss the review of literature in the United States and China. In 
chapter three, a brief composer biography and their most important songs will be presented. The analysis of each song includes information:

1. A historical background of composers and poets.

2. A brief discussion of range, tessitura, tempo, piano accompaniment, voice type, and level of difficulty. ${ }^{15}$

3. Comments for voice characteristics.

4. The English translations under the Chinese text phrase-by-phrase.

\section{Chapter II: Review of Related Literature}

While there are many studies about Chinese art songs written in Chinese, there are a few written in English as well. Most of them are dissertations by Chinese students who studied in the United States or Europe. Their research includes performance guides, music analyses, works by certain composers, and annotated bibliographies. A vast majority of their studies focus on the period before 1950. The databases considered for this project include RILM Abstract of Music Literature, JStor, ProQuest Dissertations and Theses, CNKI [in Chinese], and WanFang Data Knowledge Service Platform [in Chinese].

Seven dissertations have been found related to this topic. One of them discussed certain composers' art songs and their compositional process and styles. Two dissertations examined the development of Chinese art songs from the beginning of the 20th century to 1950 . There is one dissertation that provided annotated lists of repertoire. The other three are performance guides to selected art songs and Mandarin-Chinese diction. One article written in English can be found in JStor. It is a music and poetic analysis of Huang Zi's "Tian Lunge” (Song of Familial Bliss).

\footnotetext{
${ }^{15}$ Level of difficulty is determined based on the vocal range, dynamic range, tessitura, character, subject matter, and diction.
} 
There are only two collections of anthologies of Chinese art songs in the United States. They were both compiled by Zhong Mei, who is a Professor of Voice at Ball State University. The anthology contains 26 settings of Chinese poetry. 15 are composed by 21 st-century Chinese composers, and 11 are composed in the first half of the 20th century. Although American musicians find access to this music limited, there are some online music sources that could be used for locating scores and recordings, such as TaoBao (world.taobao.com), ZhongGuo Qupu Wang (www.qupu123.com), and Sou Pu Wang (www.sooopu.com). Books about Chinese art songs are all written in Chinese and published in China. Three of them will be included in this study. There are lots of journal articles on this topic in Chinese. Some analyze the historical development of Chinese art songs, some discuss certain composers' works and style, and others deal with the performance guides. Two key articles written by Jue Yuanjing, and Dou Zhi will be discussed.

The dissertation “Chinese art song from 1912 to 1949” written by Xiang Chen in 1995 was the earliest study written in English. Xiang's study contains two parts. The first part provides the critical social, economic, and cultural background of China from 1912 to $1949 .{ }^{16}$ The second part discusses eighteen songs composed by twelve representative Chinese composers. Xiang provides a detailed analysis for each song in terms of the structure of the texts, the music settings, and the compositional techniques. ${ }^{17}$ Translations and IPA for the Chinese text is also provided in Xiang's study. It serves as a great introductory tool for learning the repertoires from 1912 to 1949.

\footnotetext{
${ }^{16}$ Xiang Chen Hallis, "Chinese art song from 1912 to 1949” (D.M.A. diss., The University of Texas at Austin, 1995), 1, ProQuest (9617398).

${ }^{17}$ Ibid.
} 
Chi Mei-Fung Agnes Kang’s dissertation “A performance guide for contemporary Chinese art songs from Taiwan" written in 1996 includes six chapters. Chi’s study contains a collection of selected Chinese songs composed by Western-trained Chinese composers from 1949 until the present. ${ }^{18}$ In chapter two, Chi provides an introduction of music in Chinese society from ancient times (before 221 B. C.) to the Republic Period in Taiwan(1949-present). Chi also talks about the development of Chinese poetry and pronunciation for Mandarin Chinese in chapters three and four, followed by the main body of her study. For each song, Chi analyzes the poem, the piano accompaniment, as well as the performance advice for singers and pianists. Although it provides helpful information about contemporary Chinese art songs, the song repertoires are exclusively from Taiwan. The works from mainland China are not included.

Tyan Jaan-Ay’s dissertation “A performer's guide to selected Chinese art songs by twentieth-century Chinese composers" was written in 2003. The development of Chinese art songs is divided into three main periods: before 1920, from 1920 to 1949 , and after 1949 . Tyan also briefly presents the development of Chinese art songs in Taiwan. Chinese vowels and consonants are introduced in chapter three. Tyan's study includes many charts, pictures, and diagrams so it is very helpful for singers who want to learn Chinese diction. Fifteen art songs are included, focusing on interpretation. It is a great source for non-Chinese singers who want to learn Chinese and explore some art song repertoires.

“A Performance Guide to Mandarin-Chinese Diction and Selected Art Song by YiuKwong Chung” was a dissertation written by Sun Yung-Wei. In Sun's study, the development of Mandarin-Chinese art songs in Mainland China and Taiwan respectively is discussed in chapter

\footnotetext{
${ }^{18}$ Mei-Fung Agnes Kang Chi, "A performance guide for contemporary Chinese art songs from Taiwan"
} (Ed. D. diss., Teacher’s College, Columbia University, 1996), 4, ProQuest (9635963). 
two. ${ }^{19}$ Mandarin-Chinese diction is carefully examined in chapter three and chapter four; however, the discussion of song repertoires is very limited. ${ }^{20}$

Ye Zixiao’s dissertation “Four Art Songs by Guo Zurong: Art Song with Classical Chinese Poetry" focuses on discussing Guo Zurong's career and four of his art songs. Ye also includes the introduction of Chinese poetry and Chinese scale and modes in his study. The analysis of the songs focuses on the poetic overview and music setting. Although he gives a detailed analysis of the poem, poet, and compositional techniques for each song, it lacks information from a pedagogical perspective, like the range, tessitura, voice type, and difficulty level.

"The First Generation of Chinese Art Song" is a dissertation written by Zhang Tieyi. It discusses eight Chinese composers and their representative works from the 1920s to the 1950s. Twenty-four songs are included in his study and for each song, Zhang provides a brief introduction followed by the phrase-to-phrase translation. His first appendix contains a chart that indicates the key, range, tessitura, composer, and level of musical difficulty for each song. This study is helpful for singers and teachers to learn about Chinese art songs before the 1950s.

The latest dissertation for Chinese art songs in English is Chang Tingting's "A Survey of Selected Classical Chinese Art Songs for Solo Voice and Piano from 1920 to 1950.” Chang’s study serves as a repertoire guide for musicians and scholars. ${ }^{21}$ Chinese art songs in the 1920s, 1930s, and 1940s are annotated and listed from chapter three to chapter five. Each entry includes composer, piano arrangement, title, title translation, publisher, poet, poem style, difficulty level,

\footnotetext{
${ }^{19}$ Sun Yung-Wei, “A Performance Guide to Mandarin-Chinese Diction and Selected Art Song” (D.M.A. diss., Ohio State University, 2012), 6, ProQuest (10631287).

${ }^{20}$ Ibid, 15-21.

${ }^{21}$ Tingting Chang, “A Survey of Selected Classical Chinese Art Songs for Solo Voice and Piano from 1920 to $1950 ”$ (D.M.A. diss., West Virginia University), 8, ProQuest (28071684)
} 
duration, voice type, tessitura, voice characteristics, piano accompaniment, and brief comments. ${ }^{22}$ Additionally, her appendix provides phrase-to-phrase translations for each song. This study is a helpful pedagogical tool for researching Chinese art songs from 1920 to 1950.

The only article about Chinese art songs in English is Joys H. Y. Cheung's "Singing Ancient Piety and Modernity in 'Song of Familial Bliss' " (1935): Musical Translation of Huang Zi (1904-1938) in Interwar China." This article gives a careful examination of "Song of Familial Bliss", especially from a historical perspective. The conflict and combination of Western music and Chinese ancient piety is discussed in this study.

A Survey of Chinese Art Song is a book written in Chinese by Li Mingshu and Ning Ping. This book includes 40 articles which were published during the first Chinese Art Song Conference. ${ }^{23}$ The topic of these articles includes discussions of Chinese art song and Chinese culture, Chinese art song during the Cultural Revolution, the combination of folk songs and art songs, problems and difficulties in teaching Chinese art songs, the piano accompaniment, and certain composer's styles and works. ${ }^{24}$

Mo Jigang's book Performance Guidance of Chinese Art Song includes a detailed analysis of fifty Chinese art songs. It was published in China in 2003. The first part of the book gives a review of German Art Song, French Chanson, Russian Art Song, and Italian Art Song. ${ }^{25}$ The second part is the analysis of each selected song and he provides historical background, music analysis, and comments for each song. However, it lacks the information of range, tessitura, and difficulty level.

\footnotetext{
22 Ibid.

23 The first Chinese Art Song Conference was held in 2007 in Northwest University for Nationalities, China.

${ }^{24}$ Mingshu Li, and Ping Ning, A Survey of Chinese Art Song [in Chinese], (Shanghai: Shanghai Music Publishing House, 2009).

${ }^{25}$ Jigang Mo, Chinese Art Song Performance Guide [in Chinese], (Shanghai: Shanghai Music Publishing House, 2003).
} 
The Guide of Chinese Art Song is a book in Chinese written by Yang Mimi, Zheng Jie, and Zhao Lipin. It discussed the birth, development, and characteristics of Chinese art songs in different periods. This book includes two sections. The first section deals with the development of Chinese art songs from the 1920s to the establishment of the People's Republic of China, and then further to the reopening of China. The second section provides a detailed analysis of sixty representative art songs. The appendix includes a list of all the Chinese art songs from the May Fourth Movement (1919) to the 1990s. This is a comprehensive book for learning and studying Chinese art songs, however, it is only published in China and is not easily usable for nonChinese singers.

"The Development and Characteristics of Chinese Art Song after the Establishment of the People's Republic of China" is an article written by Jue Jingyuan. The first part discusses Chinese art songs from 1949 to 1966, the second part starts from 1978 to the last decade of the 20th century, and the third part introduces art songs composed in the 21st century. For each period, Jue discusses their social and cultural background, as well as the main theme and characteristics for each song. However, the repertoires mentioned in this article are very limited.

Dou Zhi's article “A Discussion of the Development of Chinese Contemporary Art Song" contains two sections. The first section describes the historical and social background of contemporary Chinese art songs. The second section presents the characteristics and influences for the songs surveyed. The article mainly discusses from the historical and cultural perspectives, but once again there is a lack of repertoires and examples.

The review of literature shows that there is a large number of studies on Chinese art songs during the first half of the 20th century. However, the studies related to the period after 1950 are extremely limited, and most of the studies mainly focus on the historical and cultural 
aspects of their subjects. This study aims at providing the non-Chinese singers and teachers a great tool for researching and learning Chinese art songs composed after 1950.

\section{Chapter III: Study of the Songs (Analysis and Translation)}

\subsection{Ding Shande (丁善德)}

Ding Shande (1911-1995) was a Chinese pianist and composer. In 1928, he attended Shang Hai National Music School where he studied piano and singing with Boris Zakharov and Vladimir Shushlin, considered China's founder of classical singing. ${ }^{26} \mathrm{He}$ also studied composition and orchestration with Huang Zi. In 1946, Ding was accepted to the Paris Conservatory, where he studied composition with Tony Aubin. ${ }^{27}$ These experiences laid the foundation for his later art song compositions. He returned to China in 1949 and began working as a composition professor at the National Academy of Music. All of Ding's art songs he wrote while he studied in Paris were destroyed or lost during the Cultural Revolution, except for the piece "Shen Mi de Di Yin" (The Mysterious Flute), which was composed in 1948 for soprano and flute. From 1948-1985, Ding composed thirty-two art songs, six of which were rearranged folk songs. ${ }^{28}$ The Chinese research on his art songs primarily focused on performance guides and the piano accompaniment. The art songs that he composed are widely studied and taught in Chinese conservatories today by composers, pianists, and singers.

\footnotetext{
${ }^{26}$ Xinlin Liao, “A Survey of Ding Shande's Art Songs," [in Chinese], (Master's thesis, Hunan Normal University, 2007), 3.

${ }^{27}$ Ibid, 5.

${ }^{28}$ Duanlin Ni, "The Creation of Ding Shangde's Art Songs" [in Chinese], Journal of Shang Hai Conservatory, 2005, 9.
} 


\subsubsection{Tai Yang Chu Lai Xi Yang Yang (The Rise of the Sun Brings us Hope and Happiness)}

The Sichuan folk song "Tai Yang Chu Lai Xi Yang Yang” is very popular in China's southwestern region. As the Sichuan basin is surrounded by mountains, there are very few hours of sunshine per year on the plateau. This song describes how people become excited when they see the sun rise and it makes them more eager to go to work. The text is written in the Sichuan dialect, making it humorous. Ding rearranged the song after the Cultural Revolution. His melody remained intact, while the rhythm was adjusted, and the piano accompaniment added.

Title Translation: The Rise of the Sun Brings us Hope and Happiness (太阳出来喜洋洋)

Poet: Jin Gu (金鼓)

Range: Ab4-F5

Tessitura: Db5-F5

Tempo: Moderate

Difficulty Level: Intermediate level

Voice Type: Soprano, tenor

Piano accompaniment: mainly block chords; staccato; the materials in the right hand of the piano double the original melody

Voice characteristics: the tessitura is hovering on the passaggio for sopranos; mostly in stepwise either descending or ascending; more difficult than it looks; needs fine phrasing. 
Hanyu Pinyin and Translation

\begin{tabular}{|c|c|c|}
\hline 太阳出来喜洋洋 & $\begin{array}{l}\text { Tài Yáng Chū Lái Xǐ Yáng } \\
\text { Yáng }\end{array}$ & $\begin{array}{l}\text { The Rise of the Sun brings us } \\
\text { Hope and Happiness }\end{array}$ \\
\hline $\begin{array}{l}\text { 太阳出来罗儿喜洋洋哦朗 } \\
\text { 罗, }\end{array}$ & $\begin{array}{l}\text { Tài Yáng Chū Lái Luó ér } \\
\text { Xǐ Yáng Yáng Láng Luó, }\end{array}$ & $\begin{array}{l}\text { The sun comes out, brings } \\
\text { people joy and happiness. }\end{array}$ \\
\hline $\begin{array}{l}\text { 挑起扁担朗朗扯光扯上山岗 } \\
\text { 吆。 }\end{array}$ & $\begin{array}{l}\text { Tiāo Qǐ Biăn Dàn Láng } \\
\text { Láng Chě Guāng Chě } \\
\text { Shàng Shān Gāng Yōo }\end{array}$ & $\begin{array}{l}\text { Picking up the shoulder pole } \\
\text { and going up the hill. }\end{array}$ \\
\hline $\begin{array}{l}\text { 手里拿把罗儿开山斧罗朗 } \\
\text { 罗, } \\
\text { 不怕虎豹朗朗扯光扯和豺狼 } \\
\text { 吆。 }\end{array}$ & $\begin{array}{l}\text { Shǒu Lǐ Ná Bǎ Luó ér Kāi } \\
\text { Shān Fǔ Luó Láng Luó, } \\
\text { Bú Pà Hǔ Bào Láng Láng } \\
\text { Chě Guāng Chě Hé Cái } \\
\text { Láng Yōo }\end{array}$ & $\begin{array}{l}\text { With a mountain axe in my } \\
\text { hand, I am not afraid of tigers, } \\
\text { leopards, and wolves. }\end{array}$ \\
\hline $\begin{array}{l}\text { 悬崖陡坎罗儿不稀罕哎郎 } \\
\text { 罗, } \\
\text { 唱起歌儿郎朗扯光扯忙砍柴 } \\
\text { 欧郎罗。 }\end{array}$ & $\begin{array}{l}\text { Xuán Yá Dǒu Kăn Luó ér } \\
\text { Bù X̄̄ Hàn Aì Láng Luó, } \\
\text { Chàng Qǐ Gē ér Lăng Lăng } \\
\text { Chě Guāng Chě Máng Kăn } \\
\text { Cái ōu Láng Luó。 }\end{array}$ & $\begin{array}{l}\text { Not afraid of the cliffs and } \\
\text { ridges. I am singing songs and } \\
\text { busy cutting firewood. }\end{array}$ \\
\hline $\begin{array}{l}\text { 走了一山罗儿又一山哎狼 } \\
\text { 罗, } \\
\text { 这山去了朗朗扯光扯那山来 } \\
\text { 欧郎罗。 }\end{array}$ & $\begin{array}{l}\text { Zǒu Lē Yì Shān Luó ér Yòu } \\
\text { Yì Shān āi Láng Luó, } \\
\text { Zhè Shān Qù Lē Láng Láng } \\
\text { Chě Guāng Chě Nà Shān } \\
\text { Laí ôu Láng Luó。 }\end{array}$ & $\begin{array}{l}\text { I am walking from one } \\
\text { mountain to another. }\end{array}$ \\
\hline $\begin{array}{l}\text { 只要我们罗儿多勤快哎郎 } \\
\text { 罗, } \\
\text { 不愁吃来朗朗扯光扯不愁穿 } \\
\text { 欧郎罗。 }\end{array}$ & $\begin{array}{l}\text { Zhǐ Yào Wǒ Mēn Duō Qīn } \\
\text { Kuaì āi Láng Luó, } \\
\text { Bù Chóu Chī Laí Láng } \\
\text { Láng Chě Guāng Chě Bù } \\
\text { Chóu Chuān ōu Láng } \\
\text { Luó。 }\end{array}$ & $\begin{array}{l}\text { As long as we are diligent, we } \\
\text { won't worry about food or } \\
\text { clothes. }\end{array}$ \\
\hline
\end{tabular}




\subsubsection{Ke Ai De Yi Duo Mei Gui Hua (A Lovely Rose)}

"Ke Ai De Yi Duo Mei Gui Hua" is a Kazakh folk song from Xinjiang. The story describes the love relationship between a Kazakh man Du Da-er and a Russian woman, Maria. In 1956, Ding Shande rearranged it as an art song. This piano accompaniment imitates the sound of the Dombra, an ancient instrument from Central and North Asia. It is written in binary form (AB). Throughout the A section, there are lyrical passages introducing the two main characters. The B section of the song is full of big jumps and high hovers, which describe their passionate love.

Title translation: A Lovely Rose (可爱的一朵玫瑰花)

Range: D4-F\#5

Tessitura: D4-A4 in A; D5-F\#5 in B

Tempo: Allegretto grazioso

Difficulty Level: Intermediate level

Voice Type: All types of voice

Piano accompaniment: frequent and tricky change of meters; right hand of the piano doubles the vocal line in a higher octave; limited dynamic range

Voice characteristics: A section includes mainly stepwise melody from D4 to A4; B section contains some third and fourth leaps, and some phrases hovers around E5 and F\#5; needs excellent phrasing. 
Hanyu Pinyin and Translation

\begin{tabular}{|c|c|c|}
\hline 可爱的一朵玫瑰花 & $\begin{array}{l}\text { Kě ài Dē Yì Duǒ Méi Guì } \\
\text { Huā }\end{array}$ & A Lovely Rose \\
\hline $\begin{array}{l}\text { 可爱的一朵玫瑰花赛帝玛 } \\
\text { 丽亚。 }\end{array}$ & $\begin{array}{l}\text { Kě ài Dē Yì Duǒ Méi Guì } \\
\text { Huā Sài Dì Mă Lì Yà。 }\end{array}$ & $\begin{array}{l}\text { A lovely rose looks like my } \\
\text { lover Sati Maria }\end{array}$ \\
\hline $\begin{array}{l}\text { 那天我在山上打猎骑着 } \\
\text { 马, } \\
\text { 正当你在山下歌唱婉转如 } \\
\text { 云霞。 }\end{array}$ & $\begin{array}{l}\text { Nà Tiān Wǒ Zài Shān } \\
\text { Shàng Dă Liè Qí Zhē Mă, } \\
\text { Zhèng Dāng Nǐ Zài Shān } \\
\text { Xià Gē Chàng Wăn Zhuăn } \\
\text { Rú Yún Xiá。 }\end{array}$ & $\begin{array}{l}\text { I was hunting and riding a horse } \\
\text { in the mountains that day when } \\
\text { you were singing at the foot of } \\
\text { the mountain. Your voice } \\
\text { sounded as beautiful as the rosy } \\
\text { clouds. }\end{array}$ \\
\hline $\begin{array}{l}\text { 歌声使我迷了路我从山坡 } \\
\text { 滚下, }\end{array}$ & $\begin{array}{l}\text { Gē Shēng Shǐ Wǒ Mí Lē } \\
\text { Lù Wǒ Cóng Shān Pō Gūn } \\
\text { Xià, }\end{array}$ & $\begin{array}{l}\text { Your beautiful singing made me } \\
\text { lost, I rolled down the hillside. }\end{array}$ \\
\hline $\begin{array}{l}\text { 哎呀呀 你的歌声婉转如云 } \\
\text { 霞。 }\end{array}$ & $\begin{array}{l}\text { Āi Yā Yā, Nǐ Dē Gē Shēng } \\
\text { Wăn Zhǔan Rú Yún Xiá。 }\end{array}$ & as the rosy clouds. \\
\hline $\begin{array}{l}\text { 强壮的青年哈萨克伊万杜 } \\
\text { 达尔。 }\end{array}$ & $\begin{array}{l}\text { Qiáng Zhuàng Dē Qīng } \\
\text { Nián Hā Sā Kè Yī Wàn Dū } \\
\text { Dá ér }\end{array}$ & $\begin{array}{l}\text { A strong and young Kazakh } \\
\text { man named Ivan Du daer. }\end{array}$ \\
\hline $\begin{array}{l}\text { 今天晚上请你过河到我 } \\
\text { 家, } \\
\text { 喂饱你的马儿带上你的冬 } \\
\text { 不拉。 }\end{array}$ & $\begin{array}{l}\text { Jīn Tīan Wăn Shàng Qǐng } \\
\text { Nǐ Guò Hé Dào Wǒ Jiā, } \\
\text { Wèi Băo Nĩ Dē Mă ér Dài } \\
\text { Shàng Nĩ Dē Dōng Bù } \\
\text { Lā。 }\end{array}$ & $\begin{array}{l}\text { Please cross the river to my } \\
\text { house tonight, feed your horse } \\
\text { and bring your Dongbula. }{ }^{29}\end{array}$ \\
\hline $\begin{array}{l}\text { 等那月儿升上来拨动你的 } \\
\text { 琴弦, } \\
\text { 哎呀呀我俩相依歌唱在树 } \\
\text { 下。 }\end{array}$ & $\begin{array}{l}\text { Děng Nà Yuè ér Shēng } \\
\text { Shàng Lái Bō Dòng Nǐ Dē } \\
\text { Qín Xián, } \\
\bar{A} \text { A Yā Yā, Wǒ Liăng Xīang } \\
\text { Yī Gē Chàng Zài Shù } \\
\text { Xià。 }\end{array}$ & $\begin{array}{l}\text { Waiting for the moon to rise, } \\
\text { you pluck your strings. Ah, we } \\
\text { are singing together under the } \\
\text { tree. }\end{array}$ \\
\hline
\end{tabular}

${ }^{29}$ Dongbula is a traditional stringed instrument of the Kazakh ethnic group of Xinjiang province. 


\subsubsection{Ma Yi La (Ma Yi La)}

"Ma Yi La", from Xinjiang, is a Kazakh folk song. Kazakh girls with the name Ma Yi La are typically beautiful and good singers. Herders liked to gather around their tents and listen to their singing. ${ }^{30}$ This folk song was reformulated by Ding as an art song in 1955 . The original melody was kept, but a lengthy prelude and postlude were added for piano accompaniment.

Title Translation: Ma Yi La (玛依拉)

Range: E4-F\#5

Tessitura: C\#5-F\#5 in A; G4-C5 in B

Tempo: Vivace

Difficulty Level: Beginner level

Voice Type: All types of female voices

Piano accompaniment: block chords; simple rhythm; long prelude and postlude; the right hand of the piano doubles the vocal line; limited dynamic range

Voice characteristics: syllabic setting; mostly small skips; fast running phrases; needs clear diction; preferably a more flexible voice.

${ }^{30}$ Xinlin Liao, “A Survey of Ding Shande's Art Songs," [in Chinese], (Master's thesis, Hunan Normal University, 2007), 12. 
Hanyu Pinyin and Translation

\begin{tabular}{|c|c|c|}
\hline 玛依拉 & Mă Ȳì Lā & Ma Yi La \\
\hline $\begin{array}{l}\text { 人们都叫我玛依拉, 诗人玛依 } \\
\text { 拉, }\end{array}$ & $\begin{array}{l}\text { Rén Mēn Dōu Jiào Wǒ Mă } \\
\text { Yī Lā, Shī Rén Mǎ Yĩ Lā, }\end{array}$ & $\begin{array}{l}\text { People call me Mayila, a } \\
\text { poet Mayila. }\end{array}$ \\
\hline 牙齿白声音好, 歌手玛依拉。 & $\begin{array}{l}\text { Yá Chǐ Bái Shēng Yīn } \\
\text { Hăo, Gē Shǒu Mǎ Yĩ Lā。 }\end{array}$ & $\begin{array}{l}\text { With white teeth and good } \\
\text { sound, I am the singer } \\
\text { Mayila. }\end{array}$ \\
\hline $\begin{array}{l}\text { 高兴时唱上一首歌, 弹起那冬不 } \\
\text { 拉冬不拉, }\end{array}$ & $\begin{array}{l}\text { Gāo Xìng Shí Chàng } \\
\text { Shàng Yì Shǒu Gē, Tán Qì } \\
\text { Dōng Bù Lā Dōng Bù Lā, }\end{array}$ & $\begin{array}{l}\text { When I am happy, I sing a } \\
\text { song and play Dongbula. }\end{array}$ \\
\hline 来往人们挤在我的屋檐底下， & $\begin{array}{l}\text { Lái Wăng Rén Mēn Jĩ Zài } \\
\text { Wǒ Dē Wū Yán Dí Xià, } \\
\end{array}$ & $\begin{array}{l}\text { People go around under my } \\
\text { roof. }\end{array}$ \\
\hline $\begin{array}{l}\text { 哈拉拉库拉依拉拉依拉哈拉拉库 } \\
\text { 拉依拉呀拉拉拉拉 }\end{array}$ & 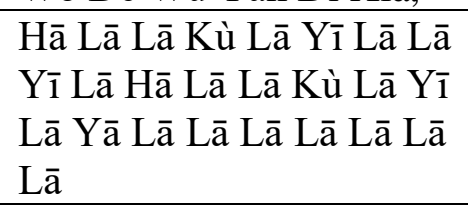 & Ha La La Ku La Yi La... \\
\hline 我是瓦利姑娘, 名叫玛依拉, & $\begin{array}{l}\text { Wǒ Shì Wă Lì Gū Niáng, } \\
\text { Míng Jiào Mǎ Yĩ Lā。 }\end{array}$ & $\begin{array}{l}\text { I am a Wali girl, my name } \\
\text { is Mayila }\end{array}$ \\
\hline 白手绢丝面上绣满了玫瑰花。 & $\begin{array}{l}\text { Bái Shǒu Juān Sī Miàn } \\
\text { Shàng Xìu Măn Lē Méi } \\
\text { Guì Huā。 }\end{array}$ & $\begin{array}{l}\text { The silk surface of my } \\
\text { white handkerchief is } \\
\text { embroidered with roses. }\end{array}$ \\
\hline $\begin{array}{l}\text { 年轻的哈萨克, 人人羡慕我羡慕 } \\
\text { 我, }\end{array}$ & $\begin{array}{l}\text { Nián Qīng Dē Hā Sā Kè, } \\
\text { Rén Rén Xiàn Mù Wǒ, }\end{array}$ & $\begin{array}{l}\text { My young Kazakh lover, } \\
\text { everyone envies me. }\end{array}$ \\
\hline 谁的歌声来和我比一下呀。 & $\begin{array}{l}\text { Shuí Dē Gē Shēng Lái Hé } \\
\text { Wǒ Bỉ Yí Xià。 }\end{array}$ & $\begin{array}{l}\text { Whose singing could } \\
\text { compare with me? }\end{array}$ \\
\hline 玛依拉拉依拉 & Mă Yī Lā Lā Yī Lā & Mayila La Yi La \\
\hline $\begin{array}{l}\text { 哈拉拉库拉依拉拉依拉哈拉拉库 } \\
\text { 拉依拉呀拉拉拉拉 }\end{array}$ & $\begin{array}{l}\text { Hā Lā Lā Kù Lā Yì Lā Lā } \\
\text { Yī Lā Hā Lā Là Kù Lā Yī } \\
\text { Lā Yā Lā Lā Lā Lā Lā Lā } \\
\text { Lāa }\end{array}$ & Ha La La Ku La Yi La... \\
\hline
\end{tabular}




\subsubsection{Huai Hua Ji Shi Kai (When the Sophora Will Blossom)}

The song is one of Ding Shande's most famous art songs. It is a rearranged Sichuan folk song. The text describes a girl's excitement for her lover's return.

Title translation: When the Sophora Will Blossom (槐花几时开)

Range: D4-F5

Tessitura: C5-F5

Tempo: Andantino

Difficulty Level: Advanced level

Voice Type: Soprano, tenor

Piano accompaniment: Long prelude; short interlude; block chords and octaves; limited dynamics; harmonically supportive to the voice

Voice characteristics: grace notes need to be sung clear; contains large upward leaps (10th);

parlando style passages; contain some local dialects; must be able to color; needs a good sense of legato. 


\section{Translation}

\begin{tabular}{|l|l|}
\hline 槐花几时开 & When the Sophora Will Blossom \\
\hline 高高山上（哟）一树（喔）槐（哟喂）， & On the mountain, there's a Sophora tree. \\
\hline 手把栏杆（噻）望郎来（哟喂）。 & $\begin{array}{l}\text { A girl holds the railing and looks for her } \\
\text { lover. }\end{array}$ \\
\hline 娘问女儿啊, 你望啥子 (哟喂)， & Her mom asks her, what are you looking for? \\
\hline (哎) 我望槐花 (噻）几时开（哟喂）。 & $\begin{array}{l}\text { She says, I am waiting for the Sophora to } \\
\text { blossom. (Because when it does, my lover } \\
\text { will come back.) }\end{array}$ \\
\hline
\end{tabular}




\subsubsection{Ai Ren Song Wo Xiang Ri Kui (My Lover Sent Me Sunflowers)}

Ding Shande composed this song in 1961. This poem describes a woman who expected her lover to give her red roses instead of sunflowers. The woman was confused when she saw the sunflowers. According to her lover, these sunflowers were planted when he first came to the countryside. Finally, the woman accepted the sunflowers and the man's love. It was written when Chairman Mao Ze Dong ordered all "educated" youths, to be known as "Zhiqing", to leave urban districts and join the rural working class. The song praises the relationship between the youths and their work in the countryside. ${ }^{31}$

Title translation: My Lover Sent Me Sunflowers (爱人送我向日葵)

Poet: Zou Difan (邹荻帆)

Range: D4-F\#5

Tessitura: G4-D5

Tempo: Andantino

Difficulty Level: Intermediate level

Voice Type: Soprano, tenor

Piano accompaniment: short prelude and postlude; simple rhythm; wide dynamic ranges; threevoice texture; arpeggiated passages in the left hand

Voice characteristics: many accidentals; syllabic setting; a long-sustained F\#5 in crescendo might be challenging since it sits around the passaggio for some sopranos; needs fine intonation.

${ }^{31}$ Lili Zhang, “A Discussion of Ding Shande's art song: Ai Ren Song Wo Mei Gui Hua” [in Chinese], Modern Music no. 13 (2017): 89. 
Translation

\begin{tabular}{|l|l|}
\hline 爱人送我向日葵 & My Lover Sent Me Sunflowers \\
\hline 我和爱人来相会, 盼他送我一直红玫瑰。 & $\begin{array}{l}\text { My lover and I came to meet; I hope that he } \\
\text { would send me the red roses. }\end{array}$ \\
\hline 哦, 没有玫瑰, 没有玫瑰, & Oh, no roses! \\
\hline 一团圆圆的向日葵。 & But a bundle of sunflowers! \\
\hline 听他语调多么美, 他是初次下乡种向日葵。 & $\begin{array}{l}\text { His voice is beautiful, he said he planted the } \\
\text { sunflowers during his first visit to the } \\
\text { countryside. }\end{array}$ \\
\hline $\begin{array}{l}\text { 啊, 向日葵呀, 小太阳啊, 在他手上放光 } \\
\text { 辉。 }\end{array}$ & $\begin{array}{l}\text { Ah! The sunflower, the little sun, shining in his } \\
\text { hand. }\end{array}$ \\
\hline $\begin{array}{l}\text { 啊! 他送我这一团向日葵, 这蜂窝一样的向 } \\
\text { 日葵。 }\end{array}$ & $\begin{array}{l}\text { Wow! He gave me this bunch of sunflowers } \\
\text { just like the honeycomb. }\end{array}$ \\
\hline 啊, 爱情的甜蜜在这里面, & Ah, the sweetness of love! \\
\hline 他教我种在窗边。 & He taught me to plant them by the window. \\
\hline $\begin{array}{l}\text { 那是他的脸儿对我来探望, 那是他向我把手 } \\
\text { 挥。 }\end{array}$ & $\begin{array}{l}\text { It was his face that came to visit me, it was him } \\
\text { who waved his hand at me. }\end{array}$ \\
\hline 哦, 爱人送我向日葵。 & Ah! My lover sent me sunflowers. \\
\hline
\end{tabular}




\subsection{Li Yinghai (黎英海)}

Chinese composer, educator, and music theorist Li Yinghai (1927-2007) is remembered for his music theories and compositions about Chinese tonal system and harmony. Among his most famous works were piano and vocal compositions. The compositions of $\mathrm{Li}$ could be categorized into two periods. In his work at Shanghai Conservatory between 1952 and 1964, he collected and arranged folk music from different regions of China. He drew a lot of inspiration from folk songs for his art songs during this period. ${ }^{32}$ Sichuan folk music was particularly influential on his works since he was born in the countryside of this province. He began teaching composition at Chinese Conservatory and Central Conservatory in 1964, where he reached the height of his composition career. ${ }^{33}$ During this period, he composed numerous song cycles and film music. His later vocal works displayed an increasing interest in setting classical Chinese poems to art songs. For example, "Feng Qiao Ye Bo" (Mooring by the Maple Bridge at Night) and "Chun Xiao" (A Spring Morning). His chamber music, piano works, and songs for children also have high aesthetic values. Such as "Xi Yang Xiao Gu" (Flute and Drum at Sunset) and "Yang Guan San Die" (Parting at Yangguan Pass). ${ }^{34}$ His Pentatonic Piano Finger Practices is China's widely used finger practice collection.

\footnotetext{
${ }^{32}$ Taotao Wu, "Songs in Poetry-Exploring the Characteristics in Li Haiying's Art Songs" [in Chinese], (Master's Thesis, Hebei Normal University, 2014), 5.

${ }^{33}$ Ran Wang, "A Research of the Characteristics and Performance Guides to Li Haiyang's Song Cycle Three Poetry from Tang Dynasty" (Master's Thesis, Jiangxi Normal University, 2018), 5.

${ }^{34}$ Xiyan Zhang, "An Analysis of the Artistic Characteristics and Performance Guides to Chun Xiao" (Master's Thesis, Sichuan Normal University, 2018), 2.
} 


\subsubsection{Xiao He Tang Shui (The Flowing River)}

The song was arranged in the 1950s from a Yun Nan folk song by Li Yinghai. The story describes how a girl was waiting for her lover in the remote countryside. In the text, the song has descriptions of the wind, the moonlight, and the river. Li kept the original melody and adjusted the rhythm while adding a piano accompaniment.

Title translation: The Flowing River (小河淌水)

Range: C4-G5

Tessitura: C5-G5

Tempo: Moderato andante

Difficulty Level: Intermediate level

Voice Type: All types of voice

Piano accompaniment: short prelude; arpeggio patterns imitating the flow of the river and the wind; most of the time, the right hand of the piano doubles the vocal line; lots of sequences; limited dynamic ranges

Voice characteristics: most suitable for a lyrical voice; needs excellent sense of phrasing; written in Chinese pentatonic mode; long phrases; many skips in small or wide intervals. 
Translation

\begin{tabular}{|l|l|}
\hline 小河淌水 & The Flowing River \\
\hline $\begin{array}{l}\text { 哎, 月亮出来亮汪汪, 亮汪汪, } \\
\text { 想起我的阿哥在深山。 }\end{array}$ & $\begin{array}{l}\text { Ah! the moon came out bright, I miss my } \\
\text { lover in the mountains }\end{array}$ \\
\hline 哥像月亮天上走, 天上走。 & He moved in the sky like the moon. \\
\hline 哥啊哥啊哥啊, 山下小河淌水清悠悠。 & $\begin{array}{l}\text { “My lover, the clear river under the mountain } \\
\text { is flowing slowly.” }\end{array}$ \\
\hline $\begin{array}{l}\text { 哎, 月亮出来照半坡, 照半坡, } \\
\text { 望见月亮想起我阿哥。 }\end{array}$ & $\begin{array}{l}\text { Ah! the moon came out to shine the hillside. I } \\
\text { thought of my lover after seeing the moon. }\end{array}$ \\
\hline 一阵清风吹上坡, 吹上坡, & $\begin{array}{l}\text { A gust of breeze blew the uphill. } \\
\text { “哥啊哥啊哥啊, 你可听见阿妹叫阿哥。 } \\
\text { you? lover, did you hear that I am calling for }\end{array}$ \\
\hline
\end{tabular}




\subsubsection{Ga O Li Tai (Ga O Li Tai)}

The Kazakh folk song was transformed into an art song by Li Yinghai in the 1950s. The song is about a love relationship between a Kazakh man and a beautiful woman named $\mathrm{Ga} \mathrm{O} \mathrm{Li}$ Tai. They fell in love with each other after their first date. Ga O Li Tai, however, was told that she would have to leave the place with her family. Ga O Li Tai left without saying good-bye to her lover. Her departure deeply saddened the Kazakh man. This song expressed the subtle mood of a man's longing for love through its elegant melody and its inner monologue. The first section of the song hovers in the mid-range of the singer's voice. The man was waiting for his lover, but she didn't appear. The second section has a higher tessitura, imitating the man calling her from a distance.

Title translation: Ga O Li Tai (嘎哦丽泰)

Range: C4-F5

Tessitura: F4-A4 in A; C5-E5 in B

Tempo: Andante moderato

Difficulty Level: Beginning level

Voice Type: All types of voice but preferably male voice

Piano accompaniment: short prelude and postlude; arpeggio in triplets; block chords

Voice characteristics: flowing and sweeping melody; small and big leaps; sustained notes on F5; syllabic setting; easy rhythm; limited dynamic ranges. 
Translation

\begin{tabular}{|l|l|}
\hline 嘎哦丽泰 & Ga O Li Tai \\
\hline 嘎俄丽泰,今天实在意外, 为何你不等待? & $\begin{array}{l}\text { Ga O Li Tai, it was really unexpected. why } \\
\text { didn’t you wait for me? }\end{array}$ \\
\hline $\begin{array}{l}\text { 野火样的心情来找你, 帐篷不在你也不 } \\
\text { 在。 }\end{array}$ & $\begin{array}{l}\text { I came to you in a hurry, but the tent wasn’t } \\
\text { there. You weren’t there. }\end{array}$ \\
\hline 啊, 嘎俄丽泰 嘎哦丽泰, 我的心爱。 & Ah! Ga O Li Tai, my lover. \\
\hline $\begin{array}{l}\text { 我徘徊在你住过的地方, } \\
\text { 已是一片荒凉, }\end{array}$ & $\begin{array}{l}\text { I have wandered the place where you lived, } \\
\text { but it is already desolate. }\end{array}$ \\
\hline $\begin{array}{l}\text { 心中情人几时才能见面? } \\
\text { 怎不叫我挂心怀。 }\end{array}$ & $\begin{array}{l}\text { When will I meet with you, my lover? How } \\
\text { could I not care? }\end{array}$ \\
$\begin{array}{l}\text { 啊, 嘎俄丽泰 嘎俄丽泰, } \\
\text { 的心爱。谁告诉我, 你搬向哪一带? }\end{array}$ & Ah! Ga O Li Tai, my lover. \\
\hline
\end{tabular}




\subsubsection{A La Mu Han (A La Mu Han)}

The Uyghur folk song A La Mu Han is very popular in Turpan. The song title is the name of a beautiful Uyghur girl. The text of the song shows a conversation. An admiration and love for A La Mu Han is described in this song.

Title Translation: A La Mu Han (阿拉木汗)

Range: Ab2-F4

Tessitura: Ab3-Db4

Tempo: Moderate

Difficulty Level: Advanced level

Voice Type: Baritone

Piano accompaniment: short prelude; staccatos; block chords; harmonically supporting the vocal line; easy rhythm

Voice characteristics: includes a big leap from F3 to F4; a sustained note on F4; lots of big leaps; syllabic setting; limited dynamic ranges. 
Translation

\begin{tabular}{|l|l|}
\hline 阿拉木汗 & A La Mu Han \\
\hline 阿拉木汗怎么样? 身段不肥也不瘦。 & $\begin{array}{l}\text { How about A La Mu Han? } \\
\text { Neither fat nor thin. }\end{array}$ \\
\hline 她的眉毛像月亮, 她的身腰像眠柳。 & $\begin{array}{l}\text { Her eyebrows are like the moon and her waist } \\
\text { is like a willow. }\end{array}$ \\
\hline 她的小嘴很多情, 眼睛使你能发抖。 & $\begin{array}{l}\text { Her small mouth is very affectionate, and her } \\
\text { eyes make you tremble. }\end{array}$ \\
\hline 阿拉木汗怎么样? 身段不肥也不瘦。 & $\begin{array}{l}\text { How about A La Mu Han? } \\
\text { Neither fat nor thin. }\end{array}$ \\
\hline 阿拉木汗住在哪里? 吐鲁番西三百六。 & $\begin{array}{l}\text { Where does A La Mu Han live? } \\
\text { Three hundred and six kilometers to the west } \\
\text { of Turfan. }\end{array}$ \\
\hline 为她黑夜没瞌睡, 为她白天常咳嗽。 & $\begin{array}{l}\text { I can't fall asleep at night because I miss her } \\
\text { so much and often cough during the day. }\end{array}$ \\
\hline 为她冒着风和雪, 为她鞋底常跑透。 & $\begin{array}{l}\text { I encountered wind and snow in my pursuit } \\
\text { for her, and my shoes are often broken. }\end{array}$ \\
\hline 阿拉木汗住在哪里? 吐鲁番西三百六。 & $\begin{array}{l}\text { Where does A La Mu Han live? } \\
\text { Three hundred and six kilometers to the west } \\
\text { of Turfan. }\end{array}$ \\
\hline
\end{tabular}




\subsubsection{Zai Yin Se De Yue Guang Xia (Under the Silver Moonlight)}

The song is originally from the Tatar ethnic group of Xinjiang. Wang Luobin, a Chinese composer and ethnomusicologist, translated the text into Mandarin Chinese. Li Yinghai later rearranged the song. There are descriptions of beach, moonlight, and dreams in the text. The song was a response to the young man's love of nature and desire for his romantic partner.

Title translation: Under the Moonlight (在银色的月光下)

Range: D4-G5

Tessitura: A4-E5

Tempo: Andantino

Difficulty Level: Intermediate level

Voice Type: Tenor, soprano

Piano accompaniment: arpeggio throughout the first and third sections; block chords for the second section; syncopated rhythms; many accidentals; broken chords; limited dynamic ranges

Voice characteristics: sweeping and flowing melody; many upward leaps in the intervals of 5th and 6th; some accidentals; many dotted rhythms; syllabic setting; sustained note on G5; strophic form. 


\section{Translation}

\begin{tabular}{|l|l|}
\hline 在银色的月光下 & Under the Silver Moonlight \\
\hline 在那金色沙滩上, 酒着银色的月光。 & $\begin{array}{l}\text { The golden sandy beach is sprinkled with } \\
\text { silver moonlight. }\end{array}$ \\
\hline $\begin{array}{l}\text { 寻找往事踪影, 往事踪影迷茫。 } \\
\text { 往事踪影迷茫, 犹如幻梦一样。 }\end{array}$ & $\begin{array}{l}\text { Searching for the memories in the past, but } \\
\text { they are fuzzy like a dream. }\end{array}$ \\
\hline 你在何处躲藏, 背弃我的姑娘。 & $\begin{array}{l}\text { Where are you hiding, the girl who betrays } \\
\text { me? }\end{array}$ \\
\hline 我骑在马上, 箭一样地飞翔。 & I am riding on a horse, flying like an arrow. \\
\hline 飞呀飞呀我的马, 朝着她去的方向。 & $\begin{array}{l}\text { Flying, Flying, riding my horse, into her } \\
\text { direction. }\end{array}$ \\
\hline
\end{tabular}




\subsubsection{Chun Xiao (A Spring Morning)}

Li Yinghai's song cycle Three Poems from the Tang Dynasty (1982) opens with this song. The poem was written by Tang dynasty poet Meng Haoran, a well-known poet of his time. He lived in the countryside, isolated from society. The love he had for nature influenced his poetic writing. He was one of China's most famous pastoral poets, having written almost four hundred poems during his lifetime. In this short poem, the poet expresses his love for spring and pity for falling flowers. ${ }^{35}$

Title translation: A Spring Morning (春晓)

Poet: Meng Haoran (孟浩然)

Range: Eb4-G5

Tessitura: Ab4-Eb5

Tempo: Largo

Difficulty Level: Intermediate level

Voice Type: Tenor, Soprano

Piano accompaniment: short prelude; broken pattern of chords; arpeggio; sustained bass notes; harmonically supporting the voice

Voice characteristics: sustained and pianissimo on F5 and G5 at the end; limited dynamic ranges; preferably a lyrical and light voice; needs excellent sense of legato line.

${ }^{35}$ Ziting Wei, "A discussion of the artistic features in classical poetry" [in Chinese], Modern Music, no. 3 (2017): 81. 
Translation

\begin{tabular}{|l|l|}
\hline 春晓 & A Spring Morning \\
\hline 春眠不觉晓, & I can barely wake up in spring morning, \\
\hline 处处闻啼鸟。 & $\begin{array}{l}\text { As the chirping of birds is heard here and } \\
\text { there. }\end{array}$ \\
\hline 夜来风雨声, & A stormy rain came last night, \\
\hline 花落知多少。 & $\begin{array}{l}\text { I am wondering how many flowers fell during } \\
\text { the storm? }\end{array}$ \\
\hline
\end{tabular}




\subsubsection{Feng Qiao Ye Bo (Mooring by the Maple Bridge at Night)}

This is the second song from Three Poems from Tang Dynasty (1982). Zhang Ji (Tang Dynasty) wrote the poem after passing Han Shan Temple during the late Tang Dynasty's Anshi rebellion. ${ }^{36}$ Through the depiction of the setting of the moon, frost at midnight, and the Hanshan Temple outside Gusu City, the poem reflects the poet's worries about his family, country, and the sadness of being in this troubled time. ${ }^{37}$ This piece has been widely performed in China's conservatories and is considered one of the sopranos' classical repertoires.

Title translation: Mooring by the Maple Bridge at Night(枫桥夜泊)

Poet: Zhang Ji (张继)

Range: B3-A5

Tessitura: G\#4-C\#4

Tempo: Lento

Difficulty Level: Intermediate level

Voice Type: Soprano

Piano accompaniment: ascending arpeggio imitates the flow of the river; sustained bass notes represent the bells; lots of grace notes; repetition; limited dynamic range

Voice characteristics: leaps in the intervals of 4th and 5th; sustained F\#5 and G5; some accidentals; more difficult than it appears.

\footnotetext{
${ }^{36}$ Huiqin Zhang, and Chenglei Deng, "Feng Qiao Ye Bo Sung by Tenor" [in Chinese], Huang He Zhi Sheng no.24 (2019), 48.

${ }^{37}$ Ibid.
} 


\section{Translation}

\begin{tabular}{|l|l|}
\hline 枫桥夜泊 & Mooring at Night by the Maple Bridge ${ }^{38}$ \\
\hline 月落乌啼霜满天, & Moon set, crows caw, frost fills the sky, \\
\hline 江枫渔火对愁眠。 & $\begin{array}{l}\text { river maples, fishing fires, drowsing in } \\
\text { sorrow. }\end{array}$ \\
\hline 姑苏城外寒山寺, & Outside Gusu city, the old Mountain Temple, \\
\hline 夜半钟声到客船。 & $\begin{array}{l}\text { the bell rings at the midnight, arrives the } \\
\text { visitor's boat. }{ }^{39}\end{array}$ \\
\hline
\end{tabular}

${ }^{38}$ Translated by Yunte Huang, a professor at the University of California, Santa Barbara.

${ }^{39}$ The visitor's boat refers to the poet's boat. 


\subsubsection{Deng Guan Que Lou (On the Stork Tower)}

This is the third song from Three Poems from Tang Dynasty (1982). It was written by Wang Zhihuan, who was a famous poet of the Tang Dynasty. The ancient Chinese tower Guan Que Lou (Stork Tower) is located in Shanxi province. The giant structure of Guan Que Lou offers stunning and breathing taking views. A great number of poems have been written about Guan Que Lou. Deng Guan Que Lou by Wang Zhihuan is the most famous one. From the top of the building, the poet watches the sun set over the Yellow River and wrote the poem without hesitating. It has become one of the most famous poems in Chinese history, and it is included in school textbooks.

Title translation: On the Stork Tower (登鹳雀楼)

Poet: Zhang Ji (张继)

Range: Db4-Ab5

Tessitura: Gb4-Db5

Tempo: Adagio

Difficulty Level: Intermediate level

Voice Type: Soprano

Piano accompaniment: short prelude; block chords; arpeggio; limited dynamic range; tremolos

Voice characteristics: includes two octave leaps; upward leap from Ab4 to Eb5 and then sustained Eb5; sustained note on Ab5 in "i” vowel; better with a dramatic voice. 


\section{Translation}

\begin{tabular}{|l|l|}
\hline 登鹳雀楼 & On the Stork Tower \\
\hline 白日依山尽, & The sun beyond the mountain glows, \\
\hline 黄河入海流。 & The Yellow River seawards flows. \\
\hline 欲穷千里目, & You can enjoy a grander sight, \\
\hline 更上一层楼。 & By climbing to a greater height. ${ }^{40}$ \\
\hline
\end{tabular}

${ }^{40}$ Translated by Xu Yuanchong (born in 1921) who is a famous translator in China. He has translated a large number of Chinese ancient poems into English and French. 


\subsection{Gu Jianfen (谷建芬)}

The famous Chinese song composer Gu Jianfen (1935-present) composed countless songs throughout her career. Composed for both stage and screen, her works include popular songs, art songs, film music, and children's songs. Her musical ability wasn't recognized during the Cultural Revolution. After 1979, China's economy, politics, and arts underwent radical change due to the Reform and Opening. The arrival of a new era inspired Gu to write songs. ${ }^{41}$ "Lan Hua Yu Hu Die" (Orchid and Butterfly) and "Na Jiu Shi Wo" (That I am) remain among her most famous art songs, and both are part of standard repertoires in today's conservatories. Her popular songs greatly influenced the generation in the 1980s, such as "Mama De Wen" (My Mum's Kiss), “Zhu Guang Li De Mama” (Mum in the Candlelight), “Si Nian” (Longing), and "Lv Ye Dui Gen De Qing Yi" (The Leaves' affection for the Roots). During the 1990s, the majority of Gu's works were compositions for TV shows and films. In this period, one of the most important pieces is “Gun Gun Chang Jiang Dong Shi Shui” (The Yangtze Flows East), from the television series San Guo Yan Yi (Three Kingdoms). ${ }^{42}$ Gu's works for children are also highly influential in China. She has published collections of works such as "Please Bring My Love Back to Home-Gu Jianfen’s Selection of Children's Songs” and “New School Songs.” By putting smooth and catchy melodies to classical Chinese poems, she allowed the children to appreciate the poetry ${ }^{43}$ Her works have influenced hundreds of millions of Chinese people and continue to inspire future generations.

${ }^{41}$ Xiaofeng Li, “A Discussion of Gu Jianfen's Songs” [in Chinese] (Master's Thesis, Shandong University, 2007), 10.

${ }^{42}$ Ibid, 11.

${ }^{43}$ Yue Guan, and Jingjin Rong, "A Survey of Gu Jianfen's Songs” [in Chinese], Bei Fang Yin Yue, no.06 (2020), 7. 


\subsubsection{Na Jiu Shi Wo (That I am)}

This art song was composed in 1982 for people who were studying or working abroad. ${ }^{44}$ It was written in ternary form in the key of E minor. The text expressed their deep attachment and longing for their home country. Xiao Guang was the poet. Since 1966, he has been writing poetry and has contributed a number of poems to contemporary Chinese art songs. His poems were published in the collections of “The Sun under the Yellow River-Xiao Guang's Poems setting to Songs," "Xiao Guang's Poems," and "Where Does My Heart Go?" His famous poems include "Zai Xi Wang De Tian Ye Shang” (On the Field of Hope), " Na Jiu Shi Wo" (That I am), and "Zai Zhong Guo Da Di Shang" (On the Land of China).

Title translation: That I am (那就是我)

Poet: Xiao Guang (晓光)

Range: D4-A5

Tessitura: D4-A5

Tempo: G4-D5

Difficulty Level: Intermediate level

Voice Type: Soprano, tenor

Piano accompaniment: broken chords; arpeggio; triplets; constantly changing of meter; harmonically supports the voice

Voice characteristics: lots of upward vocal leaps including fifths and octaves; triplets need to sing very clear; lots of sustained notes on A5; constantly changing of meter; very hard to keep the legato line.

${ }^{44}$ Yue Guan, and Jingjin Rong, “A Survey of Gu Jianfen's Songs” [in Chinese], Bei Fang Yin Yue, no.06 (2020), 8 . 
Translation

\begin{tabular}{|l|l|}
\hline 那就是我 & That I am \\
\hline $\begin{array}{l}\text { 我思恋故乡的小河, 还有河边吱吱歌唱的水 } \\
\text { 磨。 }\end{array}$ & $\begin{array}{l}\text { I miss the small river in my hometown, and } \\
\text { the squeaky water mill by the river. }\end{array}$ \\
\hline 噢, 妈妈 如果有一朵浪花向你微笑, & Ah, mom, if you see a smiling spray, \\
\hline 那就是我, 那就是我, 那就是我。 & That I am, that I am, that I am. \\
\hline $\begin{array}{l}\text { 我思恋故乡的炊烟, } \\
\text { 还有小路上赶集的牛车。 }\end{array}$ & $\begin{array}{l}\text { I miss the cooking smoke in my home, also } \\
\text { the ox carts on the small roads. }\end{array}$ \\
\hline 噢, 妈妈, 如果有一支竹笛向你吹响, & Oh, mom, if you hear a bamboo flute blow, \\
\hline 那就是我, 那就是我, 那就是我。 & That I am, that I am, that I am. \\
\hline $\begin{array}{l}\text { 我思念故乡的渔火, } \\
\text { 还有沙滩上美丽的海螺。 }\end{array}$ & $\begin{array}{l}\text { I miss the fishing fires of my hometown, also } \\
\text { the beautiful conch on the beach. }\end{array}$ \\
\hline $\begin{array}{l}\text { 噢, 妈妈, 如果有一叶风帆向你驶来, } \\
\text { 那就是我, 那就是我, 那就是我。 }\end{array}$ & $\begin{array}{l}\text { Oh, mom, if there is a sail coming towards } \\
\text { you, }\end{array}$ \\
\hline $\begin{array}{l}\text { 我思恋故乡的明月, } \\
\text { 还有青山映在水中的倒影。 }\end{array}$ & $\begin{array}{l}\text { I miss I am, that I am, that I am. } \\
\text { the reflection of the green hills in the water. }\end{array}$ \\
\hline $\begin{array}{l}\text { 噢, 妈妈, 如果你听到远方飘来的山歌。 } \\
\text { 那就是我, 那就是我, 那就是我。 }\end{array}$ & $\begin{array}{l}\text { Oh mom, if you hear a folk song from the } \\
\text { distance, }\end{array}$ \\
\hline
\end{tabular}




\subsubsection{Lan Hua Yu Hu Die (Orchid and Butterfly)}

Gu Jianfen wrote this song for political reasons in 1981. The orchid (Lan Hua) and the butterfly (Hu Die) both represent Taiwan. Taiwan is known as "Orchid Island" and "Butterfly Valley" for its orchids and butterflies. This song expressed a people's love for Taiwan through its appreciation of orchids and butterflies. ${ }^{45}$ The poet was Zhang Shixie (1932-2007), who started publishing his poems in 1951, and wrote many poems for art songs and operas. His famous works include "Shi Song Hong Jun” (Red Army Troops) and "Qiu Shou Qi Yi Ge” (Autumn Harvest Song).

Title translation: Orchid and Butterfly (兰花与蝴蝶)

Poet: Zhang Shixie (张士䜌)

Range: D4-F5

Tessitura: F4-C5

Tempo: Andante

Difficulty Level: Beginning level

Voice Type: All types of voice

Piano accompaniment: Broken chords; arpeggio; limited dynamic range; dotted rhythm; short prelude and interlude; simple rhythm

Voice characteristics: sweet and flowing melody; good for soprano to train the middle range of their voice; dotted rhythm; stepwise motion; some leaps in the interval of fourth and fifth; easy rhythm; strophic setting.

${ }^{45}$ Jingzhi Wang, "Performance Guide for Lan Hua yu Hu Die.” A Collection of Chinese Art Songs (19781995), edited by Zhou Zhenxi and Pei Chuanwen. People's Music Publisher, 2003, 177. 
Translation

\begin{tabular}{|c|c|}
\hline 兰花与蝴蝶 & Orchid and Butterfly \\
\hline $\begin{array}{l}\text { 兰花美哟兰花香, } \\
\text { 台湾兰花花中王。 }\end{array}$ & $\begin{array}{l}\text { The orchid is beautiful and fragrant, the king } \\
\text { of orchid flower is in Taiwan. }\end{array}$ \\
\hline $\begin{array}{l}\text { 在山谷在林间, } \\
\text { 碧叶飞舞金花放。 }\end{array}$ & $\begin{array}{l}\text { In the valley, among the woods, green leaves } \\
\text { are flying, and golden flowers are bloomed. }\end{array}$ \\
\hline $\begin{array}{l}\text { 兰屿岛啊蝴蝶兰, } \\
\text { 常与百花争芬芳。 }\end{array}$ & $\begin{array}{l}\text { The phalaenopsis in orchid island often } \\
\text { compete toward fragrance with other } \\
\text { hundreds of flowers. }\end{array}$ \\
\hline $\begin{array}{l}\text { 我爱台湾兰花美, } \\
\text { 花的山哪花的港。 }\end{array}$ & $\begin{array}{l}\text { I love the beauty of Taiwan orchids. Taiwan } \\
\text { is the flowers' mountain, the flowers' port. }\end{array}$ \\
\hline 啊, 祖国的宝岛我的家乡。 & $\begin{array}{l}\text { Ah, the treasure island of the motherland, my } \\
\text { hometown. }\end{array}$ \\
\hline $\begin{array}{l}\text { 蝴蝶飞哟百鸟唱, } \\
\text { 台湾蝴蝶真漂亮。 }\end{array}$ & $\begin{array}{l}\text { The butterflies are flying, the birds are } \\
\text { singing, the butterflies in Taiwan are so } \\
\text { beautiful. }\end{array}$ \\
\hline $\begin{array}{l}\text { 在山谷在湖畔, } \\
\text { 美丽的翅膀闪着光。 }\end{array}$ & $\begin{array}{l}\text { In the valley, by the lake, their beautiful } \\
\text { wings are shining. }\end{array}$ \\
\hline $\begin{array}{l}\text { 蝴蝶谷啊蝴蝶花, } \\
\text { 万紫千红绣春光。 }\end{array}$ & $\begin{array}{l}\text { The butterfly valley, the iris flowers! Spring } \\
\text { is embroidered in riots of colors. }\end{array}$ \\
\hline $\begin{array}{l}\text { 我爱台湾蝴蝶美, } \\
\text { 蝴蝶山哪蝴蝶港。 }\end{array}$ & $\begin{array}{l}\text { I love the beauty of the butterflies in Taiwan. } \\
\text { Butterfly hill, butterfly harbor. }\end{array}$ \\
\hline 啊，祖国的宝岛我的家乡。 & $\begin{array}{l}\text { Ah, the treasure island of the motherland, my } \\
\text { hometown. }\end{array}$ \\
\hline
\end{tabular}




\subsection{Luo Zhongrong (罗忠镕)}

Luo Zhong-Rong (1924-present) is a Chinese composer and educator of great influence and accomplishment. Twenty-three Chinese art songs have been composed by him. From the 1940s to the 1960s, Luo studied Paul Hindemith's theory of composition, and he was deeply influenced by Hindemith. Luo attempted to combine Western and Chinese folk music during this period, using Western techniques as a source of inspiration. ${ }^{46}$ In the 1970s, he was fascinated by impressionism and twelve-tone techniques. He reached the peak of his compositional career between 1979 and $1994 .{ }^{47}$ This was also the period during which his use of twelve-tone techniques became more refined. He was the first composer who used the twelve-tone technique for writing Chinese art songs. "She Jiang Cai Fu Rong" (Crossing the River to pick Hibiscus) composed by Luo is considered the first Chinese art song written with the twelve-tone technique. Luo, whose art songs were influenced and suppressed by the extreme "Left" political climate in the 1960s, focuses on humanism and personal experiences following the Cultural Revolution. ${ }^{48}$ His chosen text was based primarily on classical Chinese poetry, which describes love relationships, friendships, and love for his country.

\footnotetext{
${ }^{46}$ Juanji Li, "Study on Luo Zhongrong's Chinese Poetry Art Songs: A Case Study of Zhegutian" [in Chinese], Journal of Huaihai Institute of Technology (Humanities \&. Social Sciences Edition) Vol. 14 no. 9, (2016), 66.

${ }^{47}$ Ibid, 66.

${ }^{48}$ Ibid, 66.
} 


\subsubsection{She Jiang Cai Fu Rong (Crossing the River to Pick Hibiscus)}

This song was published in May 1980. China's music critic Wang Ningyi wrote an article on this song shortly after it was published. "For years, the twelve-tone technique has been a mystery in China...Luo Zhongrong bravely broke through this forbidden zone and carried out an experiment...He did not simply copy Western twelve-tone works, but through careful studying, he produced unique Chinese art songs. ${ }^{49}$ The poem was written by an anonymous author during the Han Dynasty and was included in the collection "Nineteen Classical Chinese Poetry." 50 The poem describes a man who left his hometown to pursue his dreams and one day saw some hibiscus growing beside him. He wanted to send the hibiscus to his wife. It expressed the man's love and longing for his wife and hometown.

Title translation: Crossing the River to Pick Hibiscus (涉江采芙蓉)

Range: C\#4-F5

Tempo: Slow

Difficulty Level: Intermediate level

Voice Type: Soprano

Piano accompaniment: Arpeggio; accidentals; constantly changing meters; limited dynamic range; hard ensemble

Voice characteristics: good for more advanced singers of intermediate level; needs strong intonation; mainly include stepwise motion and smaller leaps in the interval of third.

\footnotetext{
${ }^{49}$ Ningyi Wang, “A Discussion of Luo Zhongrong’s She Jiang Cai Fu Rong” [in Chinese], Music Research no.4 (1981).

${ }^{50}$ In Han Dynasty, Confucian classics became an important part of the exam for getting a position in the government and seek fame. Thousands of students left their hometown for studying. However, the capacity of the bureaucracy was too limited, which would lead to a situation where there were lots of scholars who couldn't get what they wanted. These scholars' depressed and painful feelings, as well as their longing for their remote hometowns were expressed in "Nineteen Classical Poetry."
} 
Translation

\begin{tabular}{|l|l|}
\hline 涉江采芙蓉 & Across the River to pick Hibiscus \\
\hline 涉江采芙蓉, & Boating to the river to collect bright hibiscus, \\
\hline 兰泽多芳草； & $\begin{array}{l}\text { And then to the marsh to pick fragrant blue } \\
\text { grass. }\end{array}$ \\
\hline 采之欲遗谁? & Who are the flowers in my hand for? \\
\hline 所思在远道。 & The person I miss is far away. \\
\hline 还顾望旧乡, & Looking back at my hometown, \\
\hline 长路漫浩浩。 & $\begin{array}{l}\text { I feel that I cannot see the end of the long } \\
\text { road. }\end{array}$ \\
\hline 同心而离居, & $\begin{array}{l}\text { Two lovers in love live apart in two different } \\
\text { places, }\end{array}$ \\
\hline 忧伤以终老。 & $\begin{array}{l}\text { Only loneliness and sorrow will accompany } \\
\text { them till old. }\end{array}$ \\
\hline
\end{tabular}




\subsubsection{E Mei Shan Yue Ge (Song for the Moon over Mountain E Mei)}

This song was written in 1984, and it was premiered in 1985 in West-Berlin by soprano Li Yamei and Liao Chong. ${ }^{51}$ Luo combined twelve-tone techniques and Chinese pentatonic scale with classic Chinese poetry, making the composition extremely unique. The poem was written by Li Bai when he first left his hometown in Sichuan. ${ }^{52}$ In this short poem, he mentions five places in Sichuan: E Mei Shan, Ping Qiang, San Xia, and Yu Zhou. It expresses the poet's longing for his hometown.

Title translation: Song for the Moon over Mountain E Mei（峨眉山月歌）

Poet: Li Bai (李白)

Range: G4-G5

Tempo: Lento

Difficulty Level: Intermediate level Voice Type: Soprano

Piano accompaniment: ostinato in the left hand; block chords in the right hand; limited dynamic range

Voice characteristics: some fourth and fifth upward leaps; mostly syllabic setting, with several melismatic parts; sustained note on G5; preferably a lyrical voice.

${ }^{51}$ Liu Yang, “A Comparative Study of E Mei Shan Yue Ge-Luo Zhongrong's version and Zhao Jipin's version as Examples" [in Chinese], Northern Music, (2008), 106.

${ }^{52} \mathrm{Li}$ Bai (李白) was a famous poet in Tang Dynasty. Composing thousands of poems in his life, he was regarded as "Poetic Genius." His poems were collected in "Li Tai-Bai Juan." 


\section{Translation}

\begin{tabular}{|l|l|}
\hline 峨眉山月歌 & Song for the Moon over Mountain E Mei \\
\hline 峨眉山月半轮秋, & $\begin{array}{l}\text { The half-moon over Mount Brows shines like } \\
\text { Autumn's golden brown. }\end{array}$ \\
\hline 影入平美江水流。 & $\begin{array}{l}\text { Its reflection stays in the stream while water } \\
\text { flows. }\end{array}$ \\
\hline 夜发清溪向三峡, & $\begin{array}{l}\text { I leave the Limpid Brook for the Three } \\
\text { Gorges now. }\end{array}$ \\
\hline 思君不见下渝州。 & $\begin{array}{l}\text { Now near Yuzhou, how much I miss seeing } \\
\text { you. }\end{array}$ \\
\hline
\end{tabular}




\subsubsection{Huang Hun (The Evening)}

Huang Hun was a twelve-tone piece composed in 1984, and it included twenty-one measures. In this piece, twelve-tones are broken down into three groups. The first group includes five pitches: Eb, F, Bb, Ab, C\#. These pitches are chosen from Db Gong (宫) pentatonic scale. The second group is made up of five pitches: $\mathrm{B}, \mathrm{A}, \mathrm{F}, \mathrm{E}$, and D. These pitches are included in D Gong (宫) pentatonic scale. The last group includes two pitches: C and G. In this way, Luo Zhongrong combined the uses of Chinese pentatonic scale and twelve-tone techniques in this piece. ${ }^{53}$ The poet is Shu Ting, a renowned female poet in China who has authored more than thirty collections of poetry. Some of her poems are among the most well-known poems in contemporary China.

Title translation: The Evening (黄昏)

Poet: Shu Ting (舒婷, 1952-now)

Range: Bb3-G5

Tempo: Andantino parlando

Difficulty Level: Advanced level

Voice Type: Soprano, mezzo-soprano

Piano accompaniment: block chords throughout the piece; triplets; limited dynamic range; hard to put together

Voice characteristics: two characters in the song need two different tone colors; needs excellent intonation; sometimes the left hand of the piano part is double the vocal line; stepwise ascending line from F5 to G5 and sustained on G5; lots of wide upward leaps; hard to keep the legato line.

${ }^{53}$ Juanjuan Li, "This is a Wonderful Evening-An Analysis of Luo Zhongrong's Art Song Huang Hun" in A Survey of Chinese Art Song [in Chinese], edited by Li Mingshu and Ling Ping (Shanghai: Shanghai Music Publishing House, 2009), 235. 


\section{Translation}

\begin{tabular}{|l|l|}
\hline 黄昏 & The Evening \\
\hline 我说, 我听见背后有轻轻的足音。 & I said, I heard a soft footnote behind me. \\
\hline 你说, 是微风吻着我走过的小径。 & $\begin{array}{l}\text { You said, it was the path that the breeze } \\
\text { kissed me. }\end{array}$ \\
\hline 我说, 星星象礼花一样缤纷。 & I said, the stars were as colorful as fireworks. \\
\hline 你说, 是我的睫毛沾满了花粉。 & $\begin{array}{l}\text { You said, it was my eyelashes covered with } \\
\text { pollen. }\end{array}$ \\
\hline 我说, 小雏菊都闭上了昏昏欲睡的眼睛。 & I said, the little daisy closed his sleepy eyes. \\
\hline 你说, 夜来香又开放了层层迭迭的心。 & $\begin{array}{l}\text { You said, the night lavender opened up layers } \\
\text { again. }\end{array}$ \\
\hline 我说, 这是一个生机勃勃的暮春。 & I said, it was a vibrant late spring. \\
\hline 你说, 这是一个诱人沉醉的黄昏。 & You said, it was a seductive dusk. \\
\hline
\end{tabular}




\subsection{Shi Guangnan (施光南)}

Shi Guangnan (1940-1990) was an influential Chinese composer. His works include art songs, operas, and instrumental compositions. He was a prolific composer who composed more than one thousand songs in total. Shi's art song compositions can be divided into three periods. During the period from 1949 to 1966, following the founding of PRC, China experienced a new era. In this period, "compose for society, compose for the great time" was the biggest theme for composers. The songs of Shi captured people's positive attitude toward life. "Wu Hao Hua Hong Ji Hui Jia" (Sending Five Red Flowers Home), "Shang Gong Di" (Going to the Construction Site), "Gong She Shu Ji Xia Tian Lai" (The Commute Secretary Come to the Field) were all composed during this time period. ${ }^{54}$ During the Cultural Revolution (1966-1976), Shi suffered tremendous hardships. His father had died, and his mother and cousin were being held in NiuPeng. ${ }^{55}$ However, Shi never stopped composing. His art songs "Da Qi Shou Gu Chang Qi Ge" (Play the Drum and Sing a Song) and "Ma Ling Sheng Sheng Xiang" (The Sound of Horse Bells) were both written during this period. ${ }^{56}$ After the Cultural Revolution (1976-1990), music was freed from propaganda needs, allowing Shi to compose more freely. Representative works during this period include “Tu Lu Fan De Pu Tao Shu Le" (Turpan's Grapes were Ripe), "Duo Qing De Tu Di" (The Amorous Land), "Zhu Jiu Ge" (A Drinking Song), and "Yue Guang Xia De Feng Wei Zhu" (The Phoenix under the Moonlight). A Voice Recital, featuring Shi Guangnan's works, was held in both Tianjin and Guangzhou in 1980 and 1989, respectively.

\footnotetext{
${ }^{54}$ Lixiu Zhang, “An Analysis of Shi Guangnan's Works for Voice” [in Chinese], (Master's Thesis, Shanxi University, 2012), 5.

${ }^{55}$ The prison (Niu-Peng) was built during Cultural Revolution for intellectuals.

${ }^{56}$ Lixiu Zhang, "An Analysis of Shi Guangnan's Works for Voice” [in Chinese], (Master's Thesis, Shanxi University, 2012), 5.
} 


\subsubsection{Duo Qing De Tu Di (The Amorous Land)}

This song was written in 1982 during China's reform and opening when Chinese society was going through a period of great change. Ever since China's Reform and Opening in 1978, there has been a trend of Chinese people going abroad to study or engage business. Many Chinese people desire to see the outside world, and most people are under the impression that foreign countries are developing better than China. ${ }^{57}$ Ren Zhipin (任志萍), the poet for this song, believed that only in China he could find a sense of belonging. Under this circumstance, he wrote this poem to express his love for China. He thought that China would develop slowly, and the situation would get better. ${ }^{58}$

Title translation: The Amorous Land (多情的土地)

Poet: Ren Zhipin (任志萍)

Range: C3-F4

Tempo: Adagio

Difficulty Level: Intermediate level

Voice Type: All types of male voice

Piano accompaniment: arpeggio in the left hand; block chords in the right hand; long prelude; limited dynamic range; harmonically supporting to the voice

Voice characteristics: sweet and sweeping melody; preferably lyrical voice; need excellent sense of phrasing; lots of triplets; contains some fifth and sixth upward leaps; many grace notes.

${ }^{57}$ Xianguang Zhang, "An Analysis and Performance Guide to Tu Duo Qing De Di” Xi Ju Zhi Jia, (12/2018), 82.

${ }^{58}$ Ibid. 
Translation

\begin{tabular}{|l|l|}
\hline 多情的土地 & The Amorous Land \\
\hline 我深深地爱着你, 这片多情的土地。 & I love you deeply, this amorous land. \\
\hline 我踏过的路径上, 阵阵花香鸟语。 & $\begin{array}{l}\text { The road I walked on was full of flowers and } \\
\text { the sound of the birds. }\end{array}$ \\
\hline 我耕耘过的田野上, 一层层金黄翠绿。 & $\begin{array}{l}\text { On the fields I have cultivated, there are } \\
\text { layers of golden and emerald green. }\end{array}$ \\
\hline 我怎能离开这河叉山脊, 这河叉山脊。 & $\begin{array}{l}\text { How could I leave the river and the } \\
\text { mountain? }\end{array}$ \\
\hline $\begin{array}{l}\text { 我拥抱村口的百岁洋槐, 仿佛拥抱妈妈的 } \\
\text { 身躯。 }\end{array}$ & $\begin{array}{l}\text { I hugged the hundred-year-old acacia in the } \\
\text { village, as if I was hugging my mom. }\end{array}$ \\
\hline 我深深地爱着你, 这片多情的土地。 & I love you deeply, this amorous land. \\
\hline 我时时都吸吮着, 大地母亲的乳汁。 & I am raised by my hometown, my mom. \\
\hline 我天天都接受着, 你的疼爱情意。 & I was surrounded by your love. \\
\hline 我轻轻走过这山路小溪, 这山路小溪。 & I walked gently across this mountain stream. \\
\hline $\begin{array}{l}\text { 我捧起黝黑的家乡泥土, 仿佛捧起理想的 } \\
\text { 希冀。 }\end{array}$ & $\begin{array}{l}\text { I hold the dark soil of my hometown as if I } \\
\text { hold up my dream. }\end{array}$ \\
\hline 我深深的爱着你, 这篇多情的土地。 & I love you deeply, this amorous land. \\
\hline
\end{tabular}

${ }^{59}$ The river and mountain refer to the character's hometown. 


\subsubsection{Shui Ku Ye Ge (The Melody in the Reservoir at Night)}

Shi Guangnan composed many art songs that drew inspiration from folk songs, including "Shui Ku Ye Ge." It was written in ternary form (ABA). It describes a beautiful and peaceful evening in a reservoir where a young man is working. His lover, who is far from him, expresses concern, care, and support for him. The poet is Han Wei, who works at Tianjin Opera Theatre. He has written hundreds of great poetries for art songs and the librettos for operas. Among his famous works are "Zhu Jiu Ge" (A Drinking Song), "Da Qi Shou Gu Chang Qi Ge" (Play the Drum and Sing a Song), and "Shang Shi" (Regret for the Past).

Title translation: The Melody in the Reservoir at Night (水库夜歌)

Poet: Han Wei (韩伟，1945-present)

Range: D4-C6

Tempo: Andante

Difficulty Level: Advanced level

Voice Type: Soprano

Piano accompaniment: arpeggio; block chords; harmonically supports the voice; constantly changing meter; triplets; grace notes

Voice characteristics: a very hard song; wide vocal range; only for advanced soprano; lots of ornamentations; long phrases; sustained note on C6; melismatic phrases; needs excellent breath control. 


\section{Translation}

\begin{tabular}{|l|l|}
\hline 水库夜歌 & The Melody in the Reservoir at Night \\
\hline 高山水库哟, 泛银波咯。 & $\begin{array}{l}\text { The reservoir in the mountain reflects silver } \\
\text { waves. }\end{array}$ \\
\hline 漫天星星点渔火, & The sky is full of fishing fires. \\
\hline 弯弯的月儿扬起帆咯艾。 & The crooked moon raises its sails. \\
\hline 谁在天上唱渔歌, & Who is singing a fisherman's song in the sky? \\
\hline 啊....啊.....阿... 阿... & Ah... \\
\hline 阿妹遥望哟, 高山顶咯, & $\begin{array}{l}\text { The girl looks from the distance, on the top of } \\
\text { the mountain, }\end{array}$ \\
\hline 手把琴弦轻轻拨, & plucks the strings lightly, \\
\hline 琴声飞到银河旁咯嘿, & the sound flies to the side of the Milky Way, \\
\hline 伴着月亮伴着歌。 & with the moon and the song. \\
\hline
\end{tabular}




\subsubsection{Zai Xi Wang De Tian Ye Shang (On the Fields of Hope)}

After China's Reform and Opening in 1978, China's rural areas underwent profound changes. The rural areas were thriving. ${ }^{60}$ The composer Shi Guangnan and poet Xiao Guang collaborated to create this song in praise of the new living and the new era in the countryside. ${ }^{61}$ Title translation: On the Fields of Hope (在希望的田野上)

Poet: Xiao Guang (晓光, 1948-present)

Range: F4-G5

Tempo: Allegretto

Difficulty Level: Intermediate Level

Voice Type: Soprano, tenor

Piano accompaniment: easy rhythm; staccato; ostinato in the left hand; block chords

Voice characteristics: a very happy and energetic song; sustained note on F5 and G5; mainly stepwise motion or small leaps; contains wide octave leaps from F4 to F5.

${ }^{60}$ Yang Zhou, "A Discussion of the Music Characteristics in Zai Xi Wang De Tian Ye Shang" [in Chinese], Huang He Zhi Sheng no.6 (2013): 86.

${ }^{61}$ Ibid. 
Translation

\begin{tabular}{|c|c|}
\hline 在希望的田野上 & On the Fields of Hope \\
\hline 我们的家乡，在希望的田野上。 & Our hometown is in the field of hope. \\
\hline $\begin{array}{l}\text { 炊烟在新建的住房上飘荡, 小河在美丽的 } \\
\text { 村庄旁流淌。 }\end{array}$ & $\begin{array}{l}\text { Cooking smoke waft over the newly built } \\
\text { houses, and the small river run beside the } \\
\text { beautiful village. }\end{array}$ \\
\hline $\begin{array}{l}\text { 一片冬麦 (那个) 一片高粱, } \\
\text { 十里 (哟) 荷塘 十里果香。 }\end{array}$ & The field is full of winter wheat and sorghum. \\
\hline $\begin{array}{l}\text { 哎咳哟嗬 呀儿咿儿吆, } \\
\text { 咳! 我们世世代代在这田野上生活, } \\
\text { 为她富裕, 为她兴旺。 }\end{array}$ & $\begin{array}{l}\text { Onomatopoeia } \\
\text { We have lived in this field for generations, we } \\
\text { strive for it, make it rich and prosperous. }\end{array}$ \\
\hline 我们的理想, 在希望的田野上。 & Our dream is in the field of hope. \\
\hline $\begin{array}{l}\text { 禾苗在农民的汗水里抽穗, } \\
\text { 牛羊在牧人的笛声中成长。 }\end{array}$ & $\begin{array}{l}\text { The seedlings are heading in the sweat of the } \\
\text { farmers, the cattle and sheep grow up in the } \\
\text { sound of the shepherd's flute. }\end{array}$ \\
\hline $\begin{array}{l}\text { 西村纺花 (那个) 东岗撒网, } \\
\text { 北疆（哟）播种 南国打场。 }\end{array}$ & $\begin{array}{l}\text { Spinning flowers in the western village, } \\
\text { Sowing seeds on the northern frontier, }\end{array}$ \\
\hline $\begin{array}{l}\text { 哎咳哟 嗬 呀儿咿儿哟 } \\
\text { 咳! 我们世世代代在这田野上劳动, }\end{array}$ & $\begin{array}{l}\text { Onomatopoeia } \\
\text { We have worked in this field for generations. }\end{array}$ \\
\hline $\begin{array}{l}\text { 为她打扮, 为她梳妆, } \\
\text { 我们的末来, 在希望的田野上。 }\end{array}$ & $\begin{array}{l}\text { Dress her up, our future lies in the field of } \\
\text { hope. }\end{array}$ \\
\hline
\end{tabular}




\subsubsection{Zhu Jiu Ge (A Drinking Song)}

"Zhu Jiu Ge" was written after the Cultural Revolution, when the government was trying to reestablish order in the country. In 1976, the Gang of Four was crushed, and China was full of joy, as people toasted and drank to the victory. Many composers wrote songs in celebration of the new freedom during that time. While many of the songs still followed the Cultural Revolution rules during this time, "Zhu Jiu Ge" differed from these songs in terms of the melodies and the text. ${ }^{62}$ The song describes people celebrating victory and looking forward to a better life. ${ }^{63}$

Title translation: A Drinking Song (祝酒歌)

Poet: Han Wei (韩伟) $)^{64}$

Range: Eb4-Bb5

Tempo: Andantino

Difficulty Level: Intermediate level

Voice Type: Tenor

Piano accompaniment: block chords; easy rhythm; limited dynamic range; arpeggio; fast and energetic; harmonically supports the voice

Voice characteristics: mainly stepwise up or down, with small leaps; melismatic setting; sustained note on G5 and Bb5; best for a more flexible and lighter voice.

${ }^{62}$ Meng Wu, "A Discussion of the Music Characteristics in Shi Guangnan's Art Songs-Zhu Jiu Ge as a Case Study" [in Chinese], (Master's Thesis, Xi An Conservatory, 2014), 5.

${ }^{63}$ Ibid. 


\section{Translation}

\begin{tabular}{|c|c|}
\hline 祝酒歌 & A Drinking Song \\
\hline $\begin{array}{l}\text { 美酒飘香啊歌声飞, } \\
\text { 朋友啊请你干一杯请你干一杯。 }\end{array}$ & $\begin{array}{l}\text { The wine is fragrant, and the sound of our } \\
\text { singing is flying. My friend, let's have a } \\
\text { toast. }\end{array}$ \\
\hline $\begin{array}{l}\text { 胜利的十月永难忘, } \\
\text { 杯中酒满幸福泪。 }\end{array}$ & $\begin{array}{l}\text { The victory in October will never be } \\
\text { forgotten, the wine glass is full of our tears } \\
\text { of happiness. }\end{array}$ \\
\hline 来来来…... & Onomatopoeia \\
\hline $\begin{array}{l}\text { 十月里, 响春雷, } \\
\text { 八亿神州举金杯。 }\end{array}$ & $\begin{array}{l}\text { Spring thunder ringed in October, } 800 \\
\text { million compatriots raised their wine glasses } \\
\text { together. }\end{array}$ \\
\hline $\begin{array}{l}\text { 舒心的酒啊浓又美, } \\
\text { 千杯万盍也不醉。 }\end{array}$ & $\begin{array}{l}\text { The wine makes me feel so comfortable, I } \\
\text { could drink thousands of glasses and won't } \\
\text { get drunk. }\end{array}$ \\
\hline $\begin{array}{l}\text { 手捧美酒啊望北京, } \\
\text { 豪情啊胜过长江水胜过长江水。 }\end{array}$ & $\begin{array}{l}\text { Holding my wine in hand and looking at } \\
\text { Beijing, my pride is surging like the flowing } \\
\text { of the Yangtze River. }\end{array}$ \\
\hline $\begin{array}{l}\text { 祖国前程似锦绣, } \\
\text { 万里山河尽朝晖。 }\end{array}$ & $\begin{array}{l}\text { The future of the motherland is hopeful, } \\
\text { thousands of miles of mountains and rivers } \\
\text { are under the sun. }\end{array}$ \\
\hline 来来来…... & Onomatopoeia \\
\hline $\begin{array}{l}\text { 瞻未来无限美, } \\
\text { 人人胸中春风吹。 }\end{array}$ & $\begin{array}{l}\text { Seeing the infinite beauty of our future, } \\
\text { everyone feels full of joy and happiness like } \\
\text { the spring breeze gently blows their hearts. }\end{array}$ \\
\hline $\begin{array}{l}\text { 美酒浇旺心头火, } \\
\text { 燃得斗志永不退。 }\end{array}$ & $\begin{array}{l}\text { The fine wine makes me feel the fire and } \\
\text { burns the fighting spirit in my heart, which } \\
\text { will never retreat. }\end{array}$ \\
\hline $\begin{array}{l}\text { 今天啊畅饮胜利酒, } \\
\text { 明日啊上阵劲百倍。 }\end{array}$ & $\begin{array}{l}\text { Let's drink victory wine today, tomorrow we } \\
\text { will work one hundred times harder. }\end{array}$ \\
\hline $\begin{array}{l}\text { 为了实现四个现代化, } \\
\text { 甘酒热血和汗水。 } \\
\text { 来来来….. }\end{array}$ & $\begin{array}{l}\text { To realize the Four Modernizations, we are } \\
\text { willing to strive for it. }\end{array}$ \\
\hline
\end{tabular}




\begin{tabular}{|l|l|}
\hline $\begin{array}{l}\text { 征途上战鼓擂, } \\
\text { 条条战线捷报飞。 }\end{array}$ & $\begin{array}{l}\text { We hear the sound of drumming on the road, } \\
\text { we hear the good news from every area. }\end{array}$ \\
\hline $\begin{array}{l}\text { 待到理想化宏图, } \\
\text { 再重摆美酒再相会。 }\end{array}$ & $\begin{array}{l}\text { When our dreams come true, we will serve } \\
\text { the wines and meet again. }\end{array}$ \\
\hline
\end{tabular}




\subsubsection{Wo De Zu Guo Ma Ma (My Home Country, My Mama)}

During the Cold War, there was a period of tension between East and West. Chinese scholars who left the country to pursue their dreams were worried about their country and longed to return. This song reflects their love of country and longing for home. The poem was written by Liang Shang Quan (梁上泉). He is an opera librettist who also write poetry. His representative works include "Cha Shan Xin Ge" (A New Song of The Tea Hill), "E Mei Jiu Jia" (E Mei Wineshop), “Xiao Bai Yang” (The Poplar Tree), and the opera Hong Yun Ya (Hongyun Cliff).

Title translation: My Home Country, My Mama (我的祖国妈妈)

Poet: Liang Shang Quan (梁上泉)

Range: Bb3-D5

Tempo: Moderato

Difficulty Level: Intermediate

Voice Type: Baritone; Mezzo-soprano

Piano accompaniment: triplets; arpeggio; limited dynamic range; harmonically supports the voice

Voice characteristics: dotted rhythm; stepwise motion and small leaps; a few fourth and fifth upward leaps. 
Translation

\begin{tabular}{|l|l|}
\hline 我的祖国妈妈 & My Home Country, My Mama \\
\hline $\begin{array}{l}\text { 我走遍海角天涯, } \\
\text { 忘不了祖国妈妈。 }\end{array}$ & $\begin{array}{l}\text { I traveled all over the world and can't forget } \\
\text { my motherland. }\end{array}$ \\
\hline 祖国妈妈呀, 祖国妈妈呀。 & My home country, my mama \\
\hline $\begin{array}{l}\text { 儿女在海外漂流, } \\
\text { 常思念久别的老家。 }\end{array}$ & $\begin{array}{l}\text { We lived in foreign countries, and often miss } \\
\text { our hometown. }\end{array}$ \\
\hline $\begin{array}{l}\text { 多少次托付远飞的大雁, } \\
\text { 捎给你深情的话。 }\end{array}$ & $\begin{array}{l}\text { How many times I entrusted the wild geese to } \\
\text { send you affectionate words. }\end{array}$ \\
\hline $\begin{array}{l}\text { 你听见吗, 你听见吗, } \\
\text { 我的祖国妈妈。 }\end{array}$ & $\begin{array}{l}\text { Do you hear it? My mama. } \\
\text { 我走遍海角天涯, } \\
\text { 更热爱祖国妈妈。 }\end{array}$ \\
\hline 祖国妈妈呀, 祖国妈妈呀。 & $\begin{array}{l}\text { I traveled all over the world, and love } \\
\text { motherland more. }\end{array}$ \\
\hline $\begin{array}{l}\text { 出走时满头青丝, } \\
\text { 回来时满头银发。 }\end{array}$ & My home country, my Mama \\
\hline $\begin{array}{l}\text { 却依然怀着赤子之心, } \\
\text { 献给你不谢的话。 }\end{array}$ & $\begin{array}{l}\text { When I first left you, my hair was black. } \\
\text { When I came back, my hair had turned silver. }\end{array}$ \\
\hline $\begin{array}{l}\text { 你收下吧, 你收下吧, } \\
\text { 我的祖国妈妈。 }\end{array}$ & $\begin{array}{l}\text { But I still maintain my innocent heart, I want } \\
\text { to say thank you. }\end{array}$ \\
\hline
\end{tabular}




\subsubsection{Tu Lu Fan De Pu Tao Shu Le (Turpan's Grapes are Ripe)}

This song was composed after the Reform and Opening of China in 1978. It tells a story of a Xinjiang girl named Analhan and a border warrior named Kelimu. ${ }^{65}$ Shi Guangnan adopted Uyghur folk music rhythms and tones for this song and then combined them with modern compositional methods to create a unique style. ${ }^{66}$ The poet is Qu Cong（翟琮）who has written a large number of poems for art songs. Qu Cong's works are collected in The Collected Works of Qu Cong, which includes twelve volumes. His representative works include "Wo Ai Ni Zhong Guo” (I Love You, China), “Pa Mi Er, Wo De Jia Xiang Duo Me Mei” (Pamir, How Beautiful My Hometown is), and "Wo Ai Mei Yuan Mei” (The Lovely Wintersweet in Mei Garden). Title translation: Turpan's Grapes are Ripe (吐鲁番的葡萄熟了)

Poet: Qu Cong (篗琮, 1944-present)

Range: B2-D4

Tessitura: C3-F3

Tempo: Free

Difficulty Level: Beginning level

Voice Type: All types of voices

Piano accompaniment: sequences; accidentals; staccato; block chords; arpeggio; easy rhythm; limited dynamic range; harmonically supports the voice

Voice characteristics: limited vocal range, a very good song for beginners; mainly in stepwise motion; some melismatic setting; easy rhythm.

${ }^{65}$ Yang Zhang, "The Folk Tunes used in Shi Guangnan's Art Songs" [in Chinese], Mei Li Zhong Guo, no.101 (2010), 4.

${ }^{66}$ Ibid. 
Translation

\begin{tabular}{|l|l|}
\hline 吐鲁番的葡萄熟了 & Turpan's Grapes are Ripe \\
\hline $\begin{array}{l}\text { 克里木参军去到边哨, } \\
\text { 临行时种下了一棵葡萄。 }\end{array}$ & $\begin{array}{l}\text { Kelimu joined the army and went to the } \\
\text { frontier post, he planted a grape before } \\
\text { leaving. }\end{array}$ \\
\hline $\begin{array}{l}\text { 果园的姑娘哦阿娜尔罕哟, } \\
\text { 精心培育这绿色的小苗。 }\end{array}$ & $\begin{array}{l}\text { The girl named Analhan, took care of this } \\
\text { green seedling. }\end{array}$ \\
\hline $\begin{array}{l}\text { 啊!引来了雪水把它浇灌, } \\
\text { 搭起那藤架让阳光照耀。 }\end{array}$ & $\begin{array}{l}\text { Ah! She watered it with the snow water and } \\
\text { set up the pergola for it. }\end{array}$ \\
\hline $\begin{array}{l}\text { 葡萄根儿扎根在沃土, } \\
\text { 长长蔓儿在心头缠绕。 }\end{array}$ & $\begin{array}{l}\text { The grapes are rooted in the fertile soil, the } \\
\text { long vines entangled in my heart. }\end{array}$ \\
\hline $\begin{array}{l}\text { 葡萄园几度春风秋雨, } \\
\text { 小苗儿已长得又壮又高。 }\end{array}$ & $\begin{array}{l}\text { The vineyard has gone through several } \\
\text { seasons, and the sapling has become very tall } \\
\text { and strong. }\end{array}$ \\
\hline $\begin{array}{l}\text { 当枝头结满了果实的时候, } \\
\text { 传来克里木立功的喜报。 }\end{array}$ & $\begin{array}{l}\text { When the branches are full of fruit, there } \\
\text { comes good news of Kelimu's meritorious } \\
\text { service. }\end{array}$ \\
\hline $\begin{array}{l}\text { 啊!姑娘啊遥望着雪山哨卡, } \\
\text { 捎去了一串串甜美的葡萄。 }\end{array}$ & $\begin{array}{l}\text { Ah, the girl (Analhan) is looking at the snow } \\
\text { mountain from the distance, she imagines that } \\
\text { she brings bunches of sweet grapes to her } \\
\text { lover. }\end{array}$ \\
\hline $\begin{array}{l}\text { 吐鲁番的葡萄熟了, } \\
\text { 阿娜尔罕的心儿醉了。 grapes in Turpan are ripe, Analhan's } \\
\text { heart is drunk. }\end{array}$ \\
\hline
\end{tabular}




\subsection{Shang Deyi (尚德义)}

Shang De Yi (1932-2020) was a celebrated Chinese composer. He worked as a professor at Jilin Art School and Northwest Minzu University. A major focus of his compositions in the 1950s was piano. In the 1960s, inspired by the voice techniques of his wife and by his own violin compositions, Shang began using coloratura techniques in his music compositions. His first coloratura art song was "Fei Xiang Ba, Zu Guo De Xiong Ying" (Flying, the Eagle of my Motherland). Due to the Cultural Revolution, however, this work was considered foreign and bourgeois and was unfortunately destroyed. After China's Reform and Opening in the 1970s, Shang was finally able to compose more freely.

The subject of his art songs could be divided into three categories, including praising love and nature; reflecting the situation of the country and society; and setting poems from the Tang and Song Dynasties. ${ }^{67}$ His art songs are of great aesthetic value, especially his works for coloratura sopranos. In his songs, he infused Chinese folk music with Western classical and romantic influences. ${ }^{68}$ His melodies are exquisite; his piano accompaniment is graceful. He wrote a number of groundbreaking coloratura art songs during his time. ${ }^{69}$ There are numerous thesis, articles, and books that discuss Shang's coloratura art songs. In addition to performance guides, there are also analyses of the piano accompaniment. Many of his art songs have become part of the standard repertoires at Chinese conservatories and vocal competitions.

${ }^{67}$ Deyi Shang, A New Collection of Shang Deyi's Art Songs [in Chinese], (Beijing: Central Conservatory, 2008), 32.

${ }^{68}$ Fangqin Wu, "A Discussion and Performance Guide to Shang Deyi’s Three Epochal Art Songs" [in Chinese], (Master's Thesis, Sichuan Normal University, 2013), 4.

${ }^{69}$ Ibid. 


\subsubsection{Huo Ba Jie De Huo Ba (The Torch Festival)}

The song was written in 1981 and published in 1982. Huo Ba Jie (the Torch Festival) is celebrated annually on June 24th by the Nuosuo people, which is one of China's ethnic groups living in southern central provinces of China. ${ }^{70}$ The song expresses the joy and happiness of the Nuosuo people during the Torch Festival.

Title translation: The Torch Festival (火把节的火把)

Poet: Lu Yun Sheng (卢云生, 1946-present)

Range: D\#4-C6

Tessitura: G4-C5 in A section; D\#5-G\#5 in B section

Tempo: Allegro

Difficulty Level: Advanced level

Voice Type: Coloratura Soprano

Piano accompaniment: easy rhythm; block chords; ostinato; limited dynamic range; harmonically supporting the voice

Voice characteristics: A very happy and cheerful song; lots of staccatos; mostly small leaps in A section; the second section contains lots of big vocal leaps, including fifth, sixth, and octaves.

${ }^{70}$ Chuanwei Pei, "Performance Guide to Huo Ba Jie De Huo Ba" [in Chinese], A Collection of Chinese Art Songs (1978-1995), edited by Zhou Zhenxi and Pei Chuanwen. People's Music Publisher, 2003, 176. 
Translation

\begin{tabular}{|l|l|}
\hline 火把节的火把 & The Torch Festival \\
\hline $\begin{array}{l}\text { 火把节的火把, } \\
\text { 像那鲜红的山茶。 }\end{array}$ & $\begin{array}{l}\text { The torches in the Torch Festival, like the } \\
\text { bright red camellia. }\end{array}$ \\
\hline $\begin{array}{l}\text { 开在彝家山寨里, } \\
\text { 开在月光下。 }\end{array}$ & It bloomed in the village under the moonlight. \\
\hline $\begin{array}{l}\text { 薮家心中的欢乐, } \\
\text { 白天装不下。 }\end{array}$ & $\begin{array}{l}\text { The joy in people's heart can't fit in during } \\
\text { the day. }\end{array}$ \\
\hline 在这银色的月光下, 才点燃了火把。 & Under the silver moonlight, the torch was lit. \\
\hline 啊, 赛罗赛丽赛罗赛。 & Onomatopoeia \\
\hline $\begin{array}{l}\text { 姑娘在火把下跳舞, } \\
\text { 彩裙翩翩如鲜花。 }\end{array}$ & $\begin{array}{l}\text { The girls dance under the torch, their colorful } \\
\text { skirts are like the flowers. }\end{array}$ \\
\hline $\begin{array}{l}\text { 小伙在火把下弹琴, } \\
\text { 琴弦说出心语。 }\end{array}$ & $\begin{array}{l}\text { The boys play instruments under the torch, } \\
\text { the sound of the strings speak the words in } \\
\text { their hearts. }\end{array}$ \\
\hline 老人在火把下喝酒, 丰收岁月添佳话。 & $\begin{array}{l}\text { The old man is drinking under the torch, } \\
\text { discussing the harvest season. }\end{array}$ \\
\hline 儿童在火把下玩游戏, 手捧年糕骑竹马。 & $\begin{array}{l}\text { The children are playing under the torches } \\
\text { and riding bamboo horses with rice cakes in } \\
\text { their hands. }\end{array}$ \\
\hline 啊, 赛罗赛丽赛罗赛。 & Onomatopoeia \\
\hline
\end{tabular}




\subsubsection{Ba Li Sheng Mu Yuan De Qiao Zhong Ren (The Bellringer at Notre-Dame de Paris)}

The song was composed in 1991 and premiered at the fifth CCTV Vocal Competition, the most prestigious vocal competition in China. The poem was written by Zhi Tong (志同), who is a Chinese composer and librettist. This poem was inspired by Victor Hugo's legendary novel Notre Dame de Paris. The bell-ringer Quasimodo is portrayed as a tragic character who has a hump-back and an ugly shape. ${ }^{71}$ Meanwhile, the plots reveal the protagonist's loyalty, bravery, and selflessness. ${ }^{72}$ The song is full of drama and philosophical meanings.

Title translation: The Bellringer at Notre-Dame de Paris (巴黎圣母院的敲钟人)

Poet: Zhi Tong (志同, born in 1938)

Range: C4-Ab5

Tessitura: Db5-G5

Tempo: Moderato

Difficulty Level: Advanced Level

Voice Type: Soprano

Piano accompaniment: grace notes with block chords imitate the ring bell; arpeggio; harmonically supporting the voice

Voice characteristics: could also be sung by Baritone in another key; some melismatic phrases at the end; wide octave leaps from F4 to F5; many sustained notes on F5.

${ }^{71}$ Yanfang Liu, “A Discussion of Shang Deyi’s Art Song Ba Li Sheng Mu Yuan De Qiao Zhong Ren" [in Chinese], Qilu Realm of Arts no.4 (2010).

72 Ibid. 
Translation

\begin{tabular}{|c|c|}
\hline 巴黎圣母院的敲钟人 & The Bellringer at Notre-Dame de Paris \\
\hline $\begin{array}{l}\text { 在法国巴黎圣母院, } \\
\text { 有一位孤独的敲钟人。 }\end{array}$ & $\begin{array}{l}\text { In Notre Dame de Paris, France, there's a } \\
\text { lonely bell ringer. }\end{array}$ \\
\hline $\begin{array}{l}\text { 虽然他的外表丑陃, } \\
\text { 可是他却有一颗美丽善良的心。 }\end{array}$ & $\begin{array}{l}\text { Although his appearance is ugly, he has a } \\
\text { kind heart. }\end{array}$ \\
\hline $\begin{array}{l}\text { 他年复一年, 他岁岁月月, } \\
\text { 声声敲着那教堂的大钟。 }\end{array}$ & $\begin{array}{l}\text { Year after year, he rings the bell of the } \\
\text { church. }\end{array}$ \\
\hline $\begin{array}{l}\text { 这钟声多么浑厚响亮, } \\
\text { 这钟声多么深沉激愤。 }\end{array}$ & $\begin{array}{l}\text { How strong and loud the bell ringing is. How } \\
\text { deep and indignant the bell ringing is. }\end{array}$ \\
\hline $\begin{array}{l}\text { 这钟声当当震天动地, } \\
\text { 这钟声阵阵牵人神魂。 }\end{array}$ & $\begin{array}{l}\text { The ringing is shaking the earth. The ringing } \\
\text { attracts people's souls. }\end{array}$ \\
\hline $\begin{array}{l}\text { 这钟声传送着他那赤诚的爱, } \\
\text { 也倾诉着他那埋在心底的恨。 }\end{array}$ & $\begin{array}{l}\text { The bell conveys his sincere love, also } \\
\text { confides the hatred buried in his heart. }\end{array}$ \\
\hline $\begin{array}{l}\text { 在法国巴黎圣母院, } \\
\text { 有一位孤独的敲钟人。 }\end{array}$ & $\begin{array}{l}\text { In Notre Dame de Paris, France, there's a } \\
\text { lonely bell ringer. }\end{array}$ \\
\hline $\begin{array}{l}\text { 虽然他总是默默不语, } \\
\text { 他却对世态炎凉看得清清真真。 }\end{array}$ & $\begin{array}{l}\text { Although he is always silent, he sees clearly } \\
\text { of people and the world. }\end{array}$ \\
\hline $\begin{array}{l}\text { 他含辛茹苦, 他高尚纯洁, } \\
\text { 可是终未逃脱他悲惨的命运。 }\end{array}$ & $\begin{array}{l}\text { He is hardworking, he is noble and pure, but } \\
\text { he never escapes his tragic fate. }\end{array}$ \\
\hline $\begin{array}{l}\text { 这钟声多么浑厚响亮, } \\
\text { 这钟声多么深沉激愤。 }\end{array}$ & $\begin{array}{l}\text { How strong and loud the bell ringing is. How } \\
\text { deep and indignant the bell ringing is. }\end{array}$ \\
\hline $\begin{array}{l}\text { 这钟声当当震天动地, } \\
\text { 这钟声阵阵牵人神魂。 }\end{array}$ & $\begin{array}{l}\text { The ringing is shaking the earth. The ringing } \\
\text { attracts people's souls. }\end{array}$ \\
\hline $\begin{array}{l}\text { 他宁愿去陪伴死去的吉普赛姑娘, } \\
\text { 了却他那一颗早已冰冷的心。 }\end{array}$ & $\begin{array}{l}\text { He would rather go to accompany the dead } \\
\text { gypsy girl. His heart is already dead. }\end{array}$ \\
\hline 啊... 啊... 啊. & Onomatopoeia \\
\hline
\end{tabular}




\subsubsection{Chun Feng Yuan Wu Qu (The Spring Ballade)}

This song was composed by Shang Deyi for the first spring in the 1980s. The song paints a picture of spring filled with flowers and birds. Everyone is praising the beauty of nature and expressing their hope for the future. ${ }^{73}$

Title Translation: The Spring Ballade (春风圆舞曲)

Poet: Lv Jin Zao (吕金藻)

Range: D4-D6

Tessitura: D5-G5

Tempo: Allegro

Difficulty Level: Advanced Level

Voice Type: Soprano

Piano accompaniment: block chords; some accidentals; easy rhythm; harmonically supporting the voice

Voice characteristics: only for advanced coloratura soprano; very long sustained notes on B5 and G5 at the end of the song; lots of ornamentations and coloratura phrases; needs excellent breath control.

${ }^{73}$ Yuzhu Zhou, "Performance Guidance to Shang Deyi’s art song Chun Feng Yuan Wu Qu" [in Chinese], Yin Yue Shi Kong (05/2012), 46. 
Translation

\begin{tabular}{|c|c|}
\hline 春风圆舞曲 & The Spring Ballade \\
\hline $\begin{array}{l}\text { 春风亲吻着百花的笑脸, } \\
\text { 百花飘散着迷人的芳香。 }\end{array}$ & $\begin{array}{l}\text { The spring breeze kisses the smiling face of } \\
\text { the flowers, and the flowers are full of } \\
\text { charming fragrance. }\end{array}$ \\
\hline $\begin{array}{l}\text { 桃李, 杏梅, 丁香, 玫瑰, } \\
\text { 朵朵鲜花竞相开放。 }\end{array}$ & $\begin{array}{l}\text { Peach blossom, apricot blossom, cloves, } \\
\text { roses, all the flowers are blooming. }\end{array}$ \\
\hline $\begin{array}{l}\text { 春风舒展着百鸟的翅膀, } \\
\text { 啊 }\end{array}$ & $\begin{array}{l}\text { The birds are flying with the spring breeze } \\
\text { gently caressed their wings. }\end{array}$ \\
\hline 百鸟在欢乐地歌唱。 & They are singing happily. \\
\hline $\begin{array}{l}\text { 云雀, 画眉, 杜鹃, 夜莺, } \\
\text { 歌声美妙清脆嘹亮。 }\end{array}$ & $\begin{array}{l}\text { Skylark, thrush, cuckoo, nightingale, there are } \\
\text { singing beautifully. }\end{array}$ \\
\hline $\begin{array}{l}\text { 春风荡漾, } \\
\text { 乌语花香。 }\end{array}$ & $\begin{array}{l}\text { The spring breeze is rippling, the birds are } \\
\text { singing, the flowers are fragrant. }\end{array}$ \\
\hline $\begin{array}{l}\text { 我们尽情歌唱美好的春光, } \\
\text { 啊! }\end{array}$ & We sing the beautiful spring, ah! \\
\hline 让我们尽情歌唱, 歌唱! & Let's sing, sing! \\
\hline
\end{tabular}




\subsubsection{Mu Di (The Reed Pipe)}

The song was composed in 1995. Soon after publication, it became very popular in China's conservatories and vocal competitions. A unique style was created by combining Xinjiang folk tunes with coloratura techniques. This poem was written by Shao Yongqiang (邵永 强), who was born in Lanzhou. ${ }^{74} \mathrm{He}$ began publishing his works in 1956, including novels, poems, and plays. He collaborated with Shang from the 1990s and together they have created many art songs that incorporated ethnic materials from the northeastern regions of China, including "Mu Di" (The Reed Pipe), Da Mo Zhi Ye (The Night at the Desert), and "Zou Jin Dun Huang" (Going to Dun Huang).

Title Translation: The Reed Pipe (牧笛)

Poet: Shao Yongqiang (邵永强, born in 1939)

Range: D4-B6

Tessitura: C5-G5

Tempo: Lento

Difficulty Level: Intermediate level

Voice Type: Soprano

Piano accompaniment: arpeggio; broken chords; staccato; harmonically supporting the voice; limited dynamic range

Voice characteristics: good for more advanced soprano in the intermediate level; a nice song for practicing range extension; all the coloratura passages are sung in "a" vowel; lots of wide vocal leaps like sixth and octaves.

\footnotetext{
${ }^{74}$ Lanzhou is the capital city in Gansu province. There are many different ethnic groups living in Lanzhou
} because of its special location. 
Translation

\begin{tabular}{|l|l|}
\hline 牧笛 & The Reed Pipe \\
\hline 啊, 夕阳天边陸, 晚霞多壮美。 & $\begin{array}{l}\text { The magnificent sunset is falling from the } \\
\text { horizon. }\end{array}$ \\
\hline 是谁牧笛轻轻吹, 声声多清脆, & $\begin{array}{l}\text { Who is playing the reed pipe? How crisp the } \\
\text { sound is. }\end{array}$ \\
\hline 笛声绕雪山, 笛声恋溪水, & $\begin{array}{l}\text { It sounds from the snow mountain and from } \\
\text { the streams. }\end{array}$ \\
\hline 笛声伴着青草香, 飘着奶茶味。 & $\begin{array}{l}\text { The sound of the flute is accompanied by the } \\
\text { fragrance of the green grass, and the smell of } \\
\text { the milk tea. }\end{array}$ \\
\hline 是谁牧笛轻轻吹, 阵阵暖心扉, & $\begin{array}{l}\text { Who is playing the reed pipe? It sounds so } \\
\text { heart-warming. }\end{array}$ \\
\hline 长鞭笛中响, 牛羊笛中归, & $\begin{array}{l}\text { When the reed pipe is playing, the sheep } \\
\text { returns. }\end{array}$ \\
\hline 阿爷笛中卸鞍啭，阿妈备晚炊。 & $\begin{array}{l}\text { When the reed pipe is playing, grandpa is } \\
\text { unsaddling the sheep, mom is preparing the } \\
\text { dinner. }\end{array}$ \\
\hline 啊, 笛声多悠扬, 山醉水也醉, & $\begin{array}{l}\text { The sound of the reed pipe is so melodious, } \\
\text { the mountains and the rivers also enjoy } \\
\text { listening to it. }\end{array}$ \\
\hline 牧民多欢乐, 草原笑语飞。 & $\begin{array}{l}\text { The herdsmen are so happy, they laugh, sing, } \\
\text { and dance in the grassland. }\end{array}$ \\
\hline
\end{tabular}




\subsubsection{Qi Yue De Cao Yuan (The Grassland in July)}

Shang Deyi composed this song while he was working at Northwest University in Lanzhou, where he got lots of inspirations from Xinjiang folk tunes. This song describes the grassland scenery of Xinjiang in summer, reflecting the beauty of the area and the happy lives of the people. Song Binting (宋斌廷), the poet of this song, has written a number of famous poems for art songs, such as "Hua Bu Gu Niang” (The Girl who Wears Colorful Clothes), “Qi Yue De Cao Yuan" (The Grassland in July), and "Mei Li De Da Sen Lin" (The Beautiful Forest). Title Translation: The Grassland in July (七月的草原)

Poet: Song Binting (宋斌廷)

Range: Eb4-C6

Tessitura: F4-C6

Tempo: Moderato

Difficulty Level: Advanced level

Voice Type: Soprano

Piano accompaniment: the right hand is sitting in higher register and playing the main theme; the left hand mainly stays in lower register and plays the dancing rhythm; block chords; limited dynamic range

Voice characteristics: wide vocal range; high tessitura; lots of wide leaps in the intervals of sevenths and octaves; fast and staccato coloratura passages; need a flexible voice with good sense of legato. 
Translation

\begin{tabular}{|l|l|}
\hline 七月的草原 & The Grassland in July \\
\hline 小蜜蜂采花嗡嗡的哩, & $\begin{array}{l}\text { The little bee picks the flowers and } \\
\text { buzzes... Onomatopoeia }\end{array}$ \\
啊啊啊嗡嗡的哩。 & $\begin{array}{l}\text { The butterflies dance } \\
\text { gracefully...Onomatopoeia }\end{array}$ \\
\hline $\begin{array}{l}\text { 花蝴蝶起舞翩翩的哩, } \\
\text { 阿啊啊㮼翩的哩。 }\end{array}$ & $\begin{array}{l}\text { The breeze is blowing slowly, the green } \\
\text { waves are rolling. }\end{array}$ \\
\hline $\begin{array}{l}\text { 清风儿吹来悠悠的哩, } \\
\text { 绿浪儿卷动滚滚的哩。 }\end{array}$ & $\begin{array}{l}\text { Tianshan Mountain is full of fascinating } \\
\text { sceneries, the grassland in July is so beautiful. }\end{array}$ \\
\hline $\begin{array}{l}\text { 迷人的画卷连天山, } \\
\text { 七月的草原真美丽。 }\end{array}$ & $\begin{array}{l}\text { A flock of sheep is like white } \\
\text { clous...Onomatopoeia }\end{array}$ \\
\hline $\begin{array}{l}\text { 羊群像云朵白白的哩, } \\
\text { 啊啊啊白白的哩。 }\end{array}$ & $\begin{array}{l}\text { The yurt is like a silver star (looking from the } \\
\text { distance) ...Onomatopoeia }\end{array}$ \\
\hline $\begin{array}{l}\text { 毡房像银星闪闪的哩, } \\
\text { 啊啊啊闪闪的哩。 }\end{array}$ & The boy races fast, the girl's dress is colorful. \\
\hline $\begin{array}{l}\text { 小伙子赛马快快的哩, } \\
\text { 姑娘的服饰多彩的哩。 }\end{array}$ & $\begin{array}{l}\text { The joyous lark sings non-stop, the grassland } \\
\text { in July is so beautiful. }\end{array}$ \\
\hline $\begin{array}{l}\text { 欢乐的百灵唱不停, } \\
\text { 七月的草原真美丽。 }\end{array}$ &
\end{tabular}


3.6.6 Zu Guo Yong Zai Wo Xin Zhong (My Home Country is Always in My Heart)

Shang Deyi composed this song in 1987, and it was premiered in 1988 at the fourth

CCTV Vocal Competition. The song is written in binary form (AB). In this song, the character is expressing his love for his country.

Title Translation: My Home Country is Always in My Heart (祖国永在我心中)

Poet: Zhao Lan (赵兰)

Range: D4-A5

Tessitura: D4-G4 in A section; D5-G5 in B section

Tempo: Moderato allegro

Difficulty Level: Intermediate level

Voice Type: All voice

Piano accompaniment: triplets; block chords; octaves; arpeggio; limited dynamic range; some tricky rhythms

Voice characteristics: originally written for soprano or tenor but could be sung by baritone or mezzo-soprano in different keys; mostly stepwise motion; some upward leaps in octaves; a long and sustained note in G5 at the end of the song. 
Translation

\begin{tabular}{|l|l|}
\hline 祖国永在我心中 & My Home Country is Always in My Heart \\
\hline $\begin{array}{l}\text { 我曾有数不清的梦, } \\
\text { 每个梦里都有你的身影。 }\end{array}$ & $\begin{array}{l}\text { I have had countless dreams; you are in my } \\
\text { dreams every time. }\end{array}$ \\
\hline $\begin{array}{l}\text { 我唱过数不清的歌, } \\
\text { 每首歌都把你赞美。 }\end{array}$ & $\begin{array}{l}\text { I have sung countless songs; every song } \\
\text { praises you. }\end{array}$ \\
\hline $\begin{array}{l}\text { 绿水青山养育我, } \\
\text { 阳光春风伴我行。 }\end{array}$ & $\begin{array}{l}\text { The river and mountains nourish me. The } \\
\text { sunshine and spring breeze accompany me. }\end{array}$ \\
\hline $\begin{array}{l}\text { 我的生命我的爱, } \\
\text { 都在祖国怀抱里。 }\end{array}$ & $\begin{array}{l}\text { My life, my love, all in the embrace of my } \\
\text { motherland. }\end{array}$ \\
\hline $\begin{array}{l}\text { 啊 朝朝暮暮深夜黎明, } \\
\text { 祖国你永在我心中。 }\end{array}$ & $\begin{array}{l}\text { Ah, the dawn or the night, motherland, you } \\
\text { will always be in my heart. }\end{array}$ \\
\hline $\begin{array}{l}\text { 曾有数不清的梦, } \\
\text { 每个梦里都有你的笑容。 }\end{array}$ & $\begin{array}{l}\text { I have had countless dreams. You smile is in } \\
\text { every dream. }\end{array}$ \\
\hline $\begin{array}{l}\text { 我走过数不清的路, } \\
\text { 每条路都通向北京。 }\end{array}$ & $\begin{array}{l}\text { I have traveled countless roads, every road led } \\
\text { to Beijing. }\end{array}$ \\
\hline $\begin{array}{l}\text { 黄河昆仓塑造我, } \\
\text { 万里长城万代情。 }\end{array}$ & $\begin{array}{l}\text { The Yellow River, the Kunlun Mountain, and } \\
\text { the Great Wall are inspiring me. }\end{array}$ \\
\hline $\begin{array}{l}\text { 我的理想和创造, } \\
\text { 伴随祖国齐飞腾。 }\end{array}$ & My dreams are flying with my motherland. \\
\hline $\begin{array}{l}\text { 陑 天南海北春夏秋冬, } \\
\text { 祖国你永在我心中。 }\end{array}$ & $\begin{array}{l}\text { Ah, no matter where I am, motherland, you } \\
\text { will always be in my heart. }\end{array}$ \\
\hline
\end{tabular}




\subsubsection{Lao Shi, Wo Zong Shi Xiang Qi Ni (My Teacher, I Always Miss You)}

Voice students usually perform this song at their final recitals as a way to express their appreciation and gratitude to their teachers. ${ }^{75}$ The song explains that when a student has overcome obstacles and achieved success in his studies, he always thinks of his mentor. It is written in binary form $(\mathrm{AB})$.

Title Translation: My Teacher, I Always Miss You (老师，我总是想起你)

Poet: Chang Chuncheng (常春城)

\section{Range: C4-F5}

Tessitura: C4-E4 in A section; C5-F5 in B section

Tempo: Moderato

Difficulty Level: Intermediate level

Voice Type: All voice

Piano accompaniment: ostinato (broken chords) in the left hand; triplets; block chords; sequences; limited dynamic range; easy rhythm

Voice characteristics: could be sung in all voices in different keys; the A section mainly includes stepwise motion and small leaps, very lyrical; the B section include some include some upward vocal leaps like fifths and sevenths.

\footnotetext{
${ }^{75}$ Yanming Li, "The Analysis of the Creative Features and Performance in Shang Deyi's Art Songs" [in
} Chinese], (Master's Thesis, North Minzu University, 2017), 30. 
Translation

\begin{tabular}{|c|c|}
\hline 老师, 我总是想起你 & My Teacher, I Always Miss You \\
\hline $\begin{array}{l}\text { 每当我获得成绩得到奖励, } \\
\text { 啊老师我总是想起了你。 }\end{array}$ & $\begin{array}{l}\text { Whenever I get achievements, my teacher, my } \\
\text { mentor, I always think of you. }\end{array}$ \\
\hline $\begin{array}{l}\text { 想起你慈爱的面容, } \\
\text { 想起你慈祥的话语啊。 }\end{array}$ & $\begin{array}{l}\text { Thinking of your help and kind } \\
\text { encouragement. }\end{array}$ \\
\hline 从心里默默地向你致意。 & I thank you from my heart. \\
\hline 啊亲爱的老师我怎能忘记你。 & Ah, dear teacher, how can I forget you. \\
\hline $\begin{array}{l}\text { 小苗儿结出硕果, } \\
\text { 怎能忘春风春雨。 }\end{array}$ & $\begin{array}{l}\text { When the little saplings bear fruits, how could } \\
\text { it forget the spring breeze and rain. }{ }^{76}\end{array}$ \\
\hline 啊亲爱的老师, 我怎能忘记你。 & Ah, my dear teacher, how can I forget you. \\
\hline $\begin{array}{l}\text { 你时时刻刻常在我心里, } \\
\text { 常在我, 你常在我心里。 }\end{array}$ & You are in my heart all the time. \\
\hline $\begin{array}{l}\text { 每当我有了创造得到荣誉, } \\
\text { 啊老师我总是想到了你。 }\end{array}$ & $\begin{array}{l}\text { Whenever I get achievements, my teacher, my } \\
\text { mentor, I always think of you. }\end{array}$ \\
\hline $\begin{array}{l}\text { 想到你亲切的面容, } \\
\text { 想到你慈母的话语啊, }\end{array}$ & $\begin{array}{l}\text { Thinking of your help and kind } \\
\text { encouragement. }\end{array}$ \\
\hline 从心里默默地向你敬礼。 & I thank you from my heart. \\
\hline 啊亲爱的老师我怎能忘记你。 & Ah, my dear teacher, how can I forget you. \\
\hline $\begin{array}{l}\text { 小花儿吐出芬芳, } \\
\text { 怎能忘记园丁的培育。 }\end{array}$ & $\begin{array}{l}\text { The little flower grows up, how could it forget } \\
\text { the cultivation of the gardener. }\end{array}$ \\
\hline 啊亲爱的老师, 我怎能忘记你。 & Ah, my dear teacher, how can I forget you. \\
\hline $\begin{array}{l}\text { 你时时刻刻常在我心里, } \\
\text { 常在我你常在我心里。 }\end{array}$ & You are in my heart all the time. \\
\hline
\end{tabular}

${ }^{76}$ Here, the little saplings refer to the students; the spring breeze and rain refers to their teachers. 


\subsection{Zheng Qiufeng (郑秋枫)}

Zheng Qiufeng (born in 1931) is a well-known Chinese composer, who has composed a large number of dance music, film music, chamber music, art songs, and children's songs. ${ }^{77} \mathrm{He}$ studied composition at Central South Art School in 1950 and Central Conservatory in the 1960s. His composition career was shaped by these experiences. From 1976 to 1981, composing almost two hundred songs in total, Zheng reached the peak of his art song composition. His most wellknown vocal works were all composed during this period, such as "Wo Ai Mei Yuan Mei" (The Lovely Wintersweet in Mei Garden), "Wo Ai Ni Zhong Guo" (I Love You, China), and his song cycle Zu Guo Si Ji (Four Seasons of Motherland). In his art songs, he expresses his love for his country and Chinese people's hopes for a better life. According to a music critic, "In his works there is no trace of sadness or decadence, let alone low-level vulgarity." ${ }^{" 78}$ His vocal works have been widely learned and studied at China's conservatories and music schools. Some of his works for sopranos are extremely difficult and have been regarded as "the touchstone of a good soprano."

${ }^{77}$ Xiaoxiao Zhao, “A Study on Singing and Teaching Zheng Qiufeng's Art Songs” [in Chinese], (Master's Thesis, Guangxi Normal University, 2015), 1.

${ }^{78}$ Wen Ya "The Warrior, The Singer-Zheng Qiufeng and His Works" [in Chinese], People's Music, ( 1980), 32 . 


\subsubsection{Chun-Zu Guo De Chun Tian (Spring-My Country’s Spring)}

As the song describes, after the Cultural Revolution, Chinese people were excited about the new era, which would bring them happiness and hope. This is the first song from the song cycle Zu Guo Si Ji. The song cycle was composed by Zheng Qiufeng between 1977 and 1979 for commemorating the thirtieth anniversary of the establishment of the PRC. The poet is Qu Zong. Before beginning their work, Qu Zong and Shi Guangnan visited Miao Zhai, Xinjiang, and Tian'anmen Squares to collect materials. ${ }^{79}$ The song cycle includes descriptions of four seasons throughout the country.

Title Translation: Spring-My Country’s Spring (春-祖国的春天)

Poet: Qu Zong (翟宗, 1944-present)

Range: C4-A5

Tessitura: Bb4-F5

Tempo: Andantino

Difficulty Level: Intermediate level

Voice Type: Mezzo-soprano; soprano

Piano accompaniment: block chords; triplets; fast running arpeggio; ostinato; harmonically supporting the voice

Voice characteristics: originally written in the key of F major; there are lots of upward leaps leading to a sustained F5, which might be very hard for some sopranos whose passaggio is around F5; lots of coloratura phrases in the middle section imitate the sound of the mountain spring and cuckoo; preferably sung by coloratura soprano or mezzo-soprano whose voice is flexible to sing fast-running phrases.

${ }^{79}$ Miao Zhai refers to Miao village in Guizhou province. 
Translation

\begin{tabular}{|l|l|}
\hline 春-祖国的春天 & Spring-My Country’s Spring \\
\hline 咿啊 春来了! & Ah, spring is coming! \\
\hline 冰雪消融了! & The ice and snow have melted! \\
\hline 咿啊 大地苏醒了! & Ah! This land has woken up! \\
\hline 桃花儿吐荵了, 小燕子回来了, & $\begin{array}{l}\text { The peach blossoms have bloomed, the } \\
\text { swallows are back. }\end{array}$ \\
\hline 叮咚叮咚叮咚, 山泉在唱 & Dingdong, dingdong, the stream is singing. \\
\hline $\begin{array}{l}\text { “咯咯咯咯咯咯, ” } \\
\text { 布谷鸟在叫。 }\end{array}$ & $\begin{array}{l}\text { Onomatopoeia } \\
\text { The cuckoo is calling. }\end{array}$ \\
\hline 啊, 春来了! & Ah, spring is coming! \\
\hline $\begin{array}{l}\text { 春风笑, 春意闹, } \\
\text { 百鸟鸣, 百花俏。 }\end{array}$ & $\begin{array}{l}\text { It brings spring breeze, all kinds of flowers, } \\
\text { and birds. }\end{array}$ \\
\hline 红日照山河, 祖国春光无限好。 & $\begin{array}{l}\text { The sun shines on the mountains and rivers. } \\
\text { The spring in my motherland is so beautiful! }\end{array}$ \\
\hline
\end{tabular}




\subsubsection{Qiu-Pa Mi Er, Wo De Jia Xiang Duo Me Mei (Autumn-Pamirs, How Beautiful My Hometown is)}

This is the third song from Zu Guo Si Ji. Zheng Qiufeng combined the Tajik ethnic folk tunes with fresh rhythms. ${ }^{80}$ The beats of Tajik music are mainly in $4 / 5,5 / 8,7 / 8,8 / 9,5 / 4$, and mixed beats. This song, which sits mostly in an $7 / 8$ beat, is a typical Tajik music style ${ }^{81}$ The Pamirs are in the southwest part of Xinjiang, most residents are Tajiks. ${ }^{82}$ The song describes the beautiful scenery, and the happy lives people are enjoying after China's Reform and Opening in the 1970s. It has endured for a long time and has been regarded as a valuable teaching resource at China's conservatories.

Title Translation: Autumn-Pamirs, How Beautiful My Hometown is (秋-帕米尔, 我的家乡多 么美)

Poet: Qu Zong (翟宗, 1944-present)

Range: C4-Ab5

Tessitura: Eb5-G5

Tempo: Rubato

Difficulty Level: Intermediate level

Voice Type: Soprano

Piano accompaniment: broken chords in the left hand; triplets; fast running arpeggio in the right hand; limited dynamic range; octaves; free tempo; harmonically supporting the voice

Voice characteristics: best for lyrical soprano; starting in a sustained note in Eb; upward octave leaps from G4 to G5 and sustains on G5; needs a good sense of legato line.

${ }^{80}$ Yong Xiao, "An Analysis of the third Song from Zu Guo Si Ji-Qiu, Pamir, Wo de Jia Xiang Duo Me Mei" [in Chinese], Art Communication, 2003.

${ }^{81}$ Ibid.

${ }^{82}$ Xinxin Xi, "An Analysis of the Characteristics and Performance in Qiu, Pamir, Wo De Jia Xiang Duo Me Mei" [in Chinese], Appreciation, 2018, 87. 
Translation

\begin{tabular}{|l|l|}
\hline 秋-帕米尔, 我的家乡多么美 & $\begin{array}{l}\text { Autumn-Pamirs, how beautiful my hometown } \\
\text { is }\end{array}$ \\
\hline 云雀唱着歌在天上飞, & The skylark sings and flies in the sky. \\
\hline 帕米尔啊, 我的家乡多么美。 & Pamirs, how beautiful my hometown is. \\
\hline 牧场青青牛羊肥, 青稞飘香惹人醉。 & $\begin{array}{l}\text { There are a large number of cattle and sheep } \\
\text { in the grassland. The fragrance of the } \\
\text { highland barley makes people drunk. }\end{array}$ \\
\hline 卡拉苏, 清泉水, 月亮湖, 红玫瑰, & $\begin{array}{l}\text { The clear spring water in Karasu, the red } \\
\text { roses around Moon Lake. }\end{array}$ \\
\hline 鹰笛声声吹, 骏马草场飞。 & $\begin{array}{l}\text { We hear the sound of the eagle bone flute. } \\
\text { The horse runs in the pasture. }\end{array}$ \\
\hline $\begin{array}{l}\text { 啊 弹起热瓦普, 唱起歌, 丰收的日子多甜 } \\
\text { 美。 }\end{array}$ & $\begin{array}{l}\text { Ah, playing the Rubab and singing, how } \\
\text { sweet the harvest day is. }\end{array}$ \\
\hline $\begin{array}{l}\text { 十五的月亮这般明媚, 帕米尔啊, 我的家 } \\
\text { 乡多么美。 }\end{array}$ & $\begin{array}{l}\text { The moon is so bright, Pamir, how beautiful } \\
\text { my hometown is. }\end{array}$ \\
\hline 巍巍的冰峰闪银辉, 寂静的山谷晚风吹。 & $\begin{array}{l}\text { The towering ice peaks gleam with silver, the } \\
\text { breeze blows in the valley. }\end{array}$ \\
\hline 塔合曼, 联防哨, 冰达坂, 巡逻队, & The border \\
\hline 千里边防线, 筑起铁堡垒。 & $\begin{array}{l}\text { Thousands of miles of frontier defenses built } \\
\text { a strong fortress. }\end{array}$ \\
\hline $\begin{array}{l}\text { 啊 帕米尔秋色无限美, 我会永远为你来陶 } \\
\text { 醉。 }\end{array}$ & $\begin{array}{l}\text { Ah, Pamir is infinitely beautiful in autumn, I } \\
\text { will always praise you. }\end{array}$ \\
\hline
\end{tabular}




\subsubsection{Wo Ai Mei Yuan Mei (The Lovely Wintersweet in Mei Garden)}

Premier Zhou Enlai passed away in Beijing in January 1976. This song was written by Qu Zong and Zheng Qiufeng to commemorate Zhou Enlai. Located in Nanjing, the Mei Garden is today's Mei Garden New Village. Zhou Enlai lived and worked there from 1946 to $1947 .{ }^{83}$ Featuring Jiangnan folk tunes along with Peking-opera-style, this song is one of Zheng Qiufeng's most distinctive songs. ${ }^{84}$ Title Translation: The Lovely Wintersweet in Mei Garden (我爱梅园梅)

Poet: Qu Zong (翟宗， 1944-present)

Range: D4-A5

Tessitura: A4-F\#5

Tempo: Moderato

Difficulty Level: Intermediate level

Voice Type: Soprano

Piano accompaniment: short prelude and interlude; fast running arpeggio; block chords; limited dynamic range; harmonically supporting the voice

Voice characteristics: good for lyrical soprano; mainly small leaps, occasionally wide leaps include upward fifth and sixth; easy rhythm; needs excellent sense of legato line.

${ }^{83}$ Yixing Ma, “A Discussion of Zheng Qiufeng's Art Songs” [in Chinese], (Master's Thesis, Nanjing Art School, 2009), 7.

${ }^{84}$ Jiangnan area is the name for the central eastern region in China. 


\section{Translation}

\begin{tabular}{|l|l|}
\hline 我爱梅园梅 & The Lovely Wintersweet in Mei Garden \\
\hline 不唱黄山的松, 不唱西湖的水。 & $\begin{array}{l}\text { I don't sing the pine of Huangshan. I don't } \\
\text { sing the water of West Lake. }\end{array}$ \\
\hline 石头城里歌一曲, 我唱梅园的梅。 & $\begin{array}{l}\text { In the stone town, I sing the plum blossom in } \\
\text { the Mei garden. }\end{array}$ \\
\hline $\begin{array}{l}\text { 梅园的梅, } \\
\text { 腊月里开花, 三九天吐荵。 }\end{array}$ & $\begin{array}{l}\text { The plum tree in the Mei garden bloomed in } \\
\text { twelfth lunar month. }\end{array}$ \\
\hline $\begin{array}{l}\text { 梅园的梅, } \\
\text { 不怕霜雪打, 任凭寒风吹。 }\end{array}$ & $\begin{array}{l}\text { They are not afraid of the frost or snow or } \\
\text { cold wind. }\end{array}$ \\
\hline 啊 周总理, 当年住梅园。 & \begin{tabular}{l} 
Ah, Premier Zhou lived in Mei garden. \\
\hline 红梅向阳开, 品格多高贵。
\end{tabular} \\
\hline $\begin{array}{l}\text { 梅园的梅, } \\
\text { The red blossoms towards the sun. }\end{array}$ \\
\hline 杝比杜鹃红, 她比牡丹美 \\
笑在百花前, 昂首迎春归。
\end{tabular}




\subsubsection{Wo Ai Ni, Zhong Guo (I Love My Country, China)}

This song was composed in the 1980s. It includes descriptions of the country's spring seedlings, autumn fruits, forests, mountains, and rivers. The song describes that during China's

Reform and Opening, the youth who were studying abroad wanted to return to China and contribute to building their motherland. ${ }^{85}$ It is written in strophic form.

Title Translation: I Love My Country, China (我爱你, 中国)

Poet: Qu Zong (篗宗， 1944-present)

Range: D4-A5

Tessitura: C5-A5

Tempo: Larghetto

Difficulty Level: Advanced level

Voice Type: All voices

Piano accompaniment: short prelude and long interlude; arpeggio; triplets; broken chords; wide dynamic ranges; harmonically supporting the voice

Voice characteristics: originally written for sopranos but could be sung in all voices in different keys; in the soprano key G major, an upward leap from D5 to a sustained G5 at the beginning; lots of wide upward leaps in this song; dotted rhythms; some triplets and sequences.

${ }^{85}$ Xiaoxiao Zhao, "A Study on Singing and Teaching of Zheng Qiufeng's Art Songs" [in Chinese], (Master's Thesis, Guangxi Normal University, 2015), 5. 


\section{Translation}

\begin{tabular}{|c|c|}
\hline 我爱你, 中国 & I Love My Country, China \\
\hline 百灵鸟从蓝天飞过, & The lark flies in the blue sky, \\
\hline 我爱你中国。 & I love my home country, China. \\
\hline $\begin{array}{l}\text { 我爱你春天蓬勃的秧苗, } \\
\text { 我爱你秋日金黄的硕果。 }\end{array}$ & $\begin{array}{l}\text { I love the spring blooming seedlings; I love } \\
\text { the golden autumn fruits. }\end{array}$ \\
\hline $\begin{array}{l}\text { 我爱你青松气质, } \\
\text { 我爱你红梅品格。 }\end{array}$ & $\begin{array}{l}\text { I love your green pine temperament; I love } \\
\text { your character like red plum. }\end{array}$ \\
\hline $\begin{array}{l}\text { 我爱你家乡的甜蔗, } \\
\text { 好像乳汁滋润着我的心窝。 }\end{array}$ & $\begin{array}{l}\text { I love the sweet cane of my hometown, like } \\
\text { the milk is nourishing my heart. }\end{array}$ \\
\hline $\begin{array}{l}\text { 我爱你中国， } \\
\text { 我要把最美的歌儿献给你。 }\end{array}$ & $\begin{array}{l}\text { I love you, China, I want to sing the most } \\
\text { beautiful song for you. }\end{array}$ \\
\hline 我的母亲, 我的祖国。 & My home country, My mother. \\
\hline 我爱你中国，我爱你中国。 & I love you, China. \\
\hline $\begin{array}{l}\text { 我爱你碧波滚滚的南海, } \\
\text { 我爱你白雪飘飘的北国。 }\end{array}$ & $\begin{array}{l}\text { I love the South China sea where the blue } \\
\text { waves are rolling. I love the northern land } \\
\text { where the snow flutters. }\end{array}$ \\
\hline $\begin{array}{l}\text { 我爱你森林无边, } \\
\text { 我爱你群山巍峨。 }\end{array}$ & $\begin{array}{l}\text { I love the boundless forest; I love the majestic } \\
\text { mountains. }\end{array}$ \\
\hline $\begin{array}{l}\text { 我爱你淙淙的小河, } \\
\text { 荡着清波从我的梦中流过。 }\end{array}$ & $\begin{array}{l}\text { I love the gurgling rivers which are swinging } \\
\text { waves and flowing through my dream. }\end{array}$ \\
\hline $\begin{array}{l}\text { 我爱你中国, 我爱你中国, } \\
\text { 我要把美好的青春献给你, }\end{array}$ & $\begin{array}{l}\text { I love you, China, I want to strive and work } \\
\text { hard for your future. }\end{array}$ \\
\hline 我的母亲, 我的祖国。 & My mother, my home country. \\
\hline
\end{tabular}




\subsection{Lu Zaiyi (陆在易)}

Lu Zaiyi (陆在易, born in 1943) is a contemporary Chinese composer. His works span many different genres, including Peking Opera, dance music, orchestral music, chorus music, and art songs. Among his most famous works are his art songs. Lu has made unprecedented contributions to the development of Chinese art songs ${ }^{86}$ His art song composition can be divided into two phases. ${ }^{87}$ After the Cultural Revolution and the Reform and Opening of China, Lu achieved his first peak in the 1980s ${ }^{88}$ The art songs composed during this period were characterized by joy and happiness. The second stage was from the 1990s to the present. During this period, living conditions improved steadily. Lu, however, grew concerned about the future of the country and was called a "sorrowful poet." In his art songs from this period, he presented a depressing and melancholy mood. Among his representative works were "Qiao" (The Bridge), "Jia" (Hometown), "Pang" (Longing), and "Wo Ai Zhe Tu Di" (I Love This Land). His vocal works are collected in "Lu Zaiyi’s Art Songs" and "Lu Zaiyi’s Choir Works." ${ }^{\prime 9}$ There are many researches on Lu Zaiyi's art songs, including performance guides, discussions on the piano accompaniment, and aesthetic attributes. In China's academies, his art songs are widely used and studied.

\footnotetext{
${ }^{86}$ Meng Li, "The Characteristics and Performance Guide to Lu Zaiyi's Art Songs" [in Chinese], (Master's Thesis, Shandong Normal University, 2014), 2.

${ }^{87}$ Yancun Xin, "A Research of the Melodic Techniques in Lu Zaiyi's Art Songs" [in Chinese], (Master's Thesis, Zhejiang Normal University, 2015), 11.

${ }^{88} \mathrm{Ibid}, 12$.

89 《陆在易艺术歌曲选》和《陆在易合唱作品选》
} 


\subsubsection{Zu Guo-Ci Xiang De Mu Qin (My Country, My Kind Mom)}

Lu Zaiyi composed this song in 1981 when he was in his early 30s. It expressed people's hope for a new life and love for the country after the Cultural Revolution. Lu believed this song was not written as an art song but a popular song for ordinary people to sing. However, it was listed as an art song later, and it has become a standard repertoire for voice students in Chinese conservatories. ${ }^{90}$ The song was written in binary form (AB). Section A expressed the character's appreciation for his mother, Section B described his love for his country. ${ }^{91}$

Title Translation: My Country, My Kind Mom (祖国，慈祥的母亲)

Poet: Zhang Hongxi (张鸿西)

Range: D4-G5

Tessitura: B4-E5

Tempo: Adagietto

Difficulty Level: Intermediate level

Voice Type: All types of voice

Piano accompaniment: short prelude; block chords; limited dynamic ranges; harmonically supporting the voice.

Voice characteristics: preferably performed by tenor or soprano but could also be sung in different keys by mezzo-soprano or baritone; mostly in stepwise motion, occasionally some upward leaps in fourths; easy rhythm; ending in a sustained note E4.

${ }^{90}$ Ding Liu, "The Artistic Characteristics in Lu Ziayi's Art Songs" in A Survey of Chinese Art Song [in Chinese], edited by Li Mingshu, and Ning Ping (Shanghai: Shanghai Music Publishing House, 2009), 222.

${ }^{91}$ Ibid, 226. 
Translation

\begin{tabular}{|c|c|}
\hline 祖国, 慈祥的母亲 & My Country, My Kind Mom \\
\hline $\begin{array}{l}\text { 谁不爱自己的母亲, 用那滚烫的赤子心 } \\
\text { 灵。 }\end{array}$ & $\begin{array}{l}\text { Who doesn't love his mother, with the } \\
\text { warmest heart? }\end{array}$ \\
\hline 亲爱的祖国慈祥的母亲。 & Dear motherland, kind mother. \\
\hline $\begin{array}{l}\text { 长江黄河欢腾着欢腾着深情, } \\
\text { 我们对您的深情。 }\end{array}$ & $\begin{array}{l}\text { The Yangtze River and the Yellow River are } \\
\text { expressing our affection and love for you. }\end{array}$ \\
\hline $\begin{array}{l}\text { 谁不爱自己的母亲, 用那闪光的美妙青 } \\
\text { 春。 }\end{array}$ & $\begin{array}{l}\text { Who doesn't love his mother? Who doesn't } \\
\text { want to work for his future? }\end{array}$ \\
\hline 亲爱的祖国慈祥的母亲。 & Dear motherland, kind mother. \\
\hline $\begin{array}{l}\text { 蓝天大海充满着充满着忠诚, } \\
\text { 我们对您的忠诚。 }\end{array}$ & $\begin{array}{l}\text { The blue sky and the sea are full of loyalty. } \\
\text { Our loyalty to you. }\end{array}$ \\
\hline
\end{tabular}




\subsubsection{Cai Yun Yu Xian Hua (The Colorful Clouds and Flowers)}

This song, written in through-composed form (ABC) in 1981 for coloratura sopranos, was based mainly on Chinese pentatonic scales with ornamentations in some parts. ${ }^{92}$ The song describes a beautiful border village girl praising the great mountains and rivers of the country. Title Translation: The Colorful Clouds and Flowers (彩云与鲜花)

Poet: Zhang Hongxi (张鸿西)

Range: D4-D6

Tessitura: G4-D5 in A section; B4-F5 in B section; E5-C6 in C section

Tempo: Rubato; Adagio

Difficulty Level: Advanced level

Voice Type: Coloratura Soprano

Piano accompaniment: short prelude; block chords; accidentals; arpeggio; some complex rhythmic figures; change of meters; triplets; harmonically supporting the voice

Voice characteristics: only for coloratura soprano in advanced level; mostly stepwise motion in A section; some upward leaps in fifths in B section; fast running coloratura phrases in C section; sustained note on $\mathrm{C} 6$; wide dynamic ranges; some tricky rhythms.

92 Ding Liu, "The Artistic Characteristics in Lu Ziayi's Art Songs" in A Survey of Chinese Art Song [in Chinese], edited by Li Mingshu, and Ning Ping (Shanghai: Shanghai Music Publishing House, 2009), 222. 
Translation

\begin{tabular}{|l|l|}
\hline 彩云与鲜花 & The Colorful Clouds and Flowers \\
\hline 山想清泉树想春, & $\begin{array}{l}\text { The mountain thinks of the streams while the } \\
\text { trees think of the spring. }\end{array}$ \\
\hline 姑娘啊姑娘你想什么? & Girl, what are you thinking of? \\
\hline $\begin{array}{l}\text { 我想变成彩云, } \\
\text { 飞遍壮丽的山河, }\end{array}$ & $\begin{array}{l}\text { I want to become the colorful clouds which } \\
\text { could fly over the magnificent mountains and } \\
\text { rivers. }\end{array}$ \\
\hline $\begin{array}{l}\text { 我想变成鲜花, } \\
\text { 装点芬芳的生活。 }\end{array}$ & $\begin{array}{l}\text { I want to become flowers which could } \\
\text { decorate people's lives. }\end{array}$ \\
\hline $\begin{array}{l}\text { 我想变成彩云, } \\
\text { 伴随勇敢的银燕, }\end{array}$ & $\begin{array}{l}\text { I want to be the colorful clouds which could } \\
\text { fly with the swallows. }\end{array}$ \\
\hline $\begin{array}{l}\text { 想变成鲜花, } \\
\text { 开放在亲人的心窝。 }\end{array}$ & $\begin{array}{l}\text { I want to become flowers which will bloom in } \\
\text { the heart of my loved ones. }\end{array}$ \\
\hline
\end{tabular}




\subsubsection{Wo Ai Zhe Tu Di (I Love this Land)}

One of Lu Zaiyi's published art song collections is titled with this song. ${ }^{93}$ "This is the pinnacle of Lu Zaiyi's composition as it is exceptionally long and powerful, its emotions are deeply felt, and the accompaniment features exquisite piano accompaniment. It is difficult to sing and perform... which is an exceptional find from the establishment of the PRC," commented Ju Qihong, a famous Chinese composer and critic. ${ }^{94}$ The poem was written by the famous Chinese poet Ai Qing, who wrote a large number of poems and made a significant contribution to Chinese literature. This poem was written in 1938 in the midst of the Second Sino-Japanese War, when China was suffering hard times fighting against the invaders. The poem expressed the poet's deep love for the country.

Title Translation: I Love this Land (我爱这土地)

Poet: Ai Qing (艾青，1910-1996)

Range: Db4-Bb5

Tessitura: Ab4-Db5

Tempo: Moderato

Difficulty Level: Advanced level

Voice Type: Soprano

Piano accompaniment: long prelude and interlude; lots of accidentals; mostly fast running arpeggio; some block chords; wide dynamic range; constantly changes of meter; harmonically supporting the voice

Voice characteristics: a very long and dramatic art song, more like an aria; best for dramatic soprano, but could also be sung with a lyrical voice; include some phrases like recitative in arias;

93 “I Love this Land-Lu Zaiyi's Art Songs" include seven of his representative works: Qiao (The Bridge), Jia (Home), Pang (Longing), Cai Yun Yu Xian Hua (Colorful Clouds and Flowers), Zui Hou Yi Ge Meng (The Last Dream), and Wo Ai Zhe Tu Di (I Love this Land). This collection was published in 2002 and was the first Chinese art songs collection with a CD in it.

${ }^{94}$ Qihong Ju, “A Poet with Love-Lu Zaiyi and his Vocal Composition” [in Chinese], People's Music no.11, 2004, 4-8. 
lots of wide leaps include sixths and octaves; ending on a sustained note Gb5; dynamic changes(crescendo) on a sustained note; constantly changes of meter.

\section{Translation}

\begin{tabular}{|l|l|}
\hline 我爱这土地 & I Love this Land \\
\hline $\begin{array}{l}\text { 假如我是一只鸟, } \\
\text { 我也应该用嘶哑的喉咙歌唱。 }\end{array}$ & $\begin{array}{l}\text { If I were a bird, I would sing with a hoarse } \\
\text { throat. }\end{array}$ \\
\hline $\begin{array}{l}\text { 这被暴风雨所打击着的土地, } \\
\text { 这永远汹涌着我们的悲愤的河流。 }\end{array}$ & $\begin{array}{l}\text { This land is hitting by the storm. The river is } \\
\text { flowing full of our grief and anger. }\end{array}$ \\
\hline $\begin{array}{l}\text { 这无止息地吹刮着的激怒的风, } \\
\text { 和那来自林间的无比温柔的黎明。 }\end{array}$ & $\begin{array}{l}\text { I see the irritating wind is blowing endlessly, } \\
\text { and the incomparably gentle dawn from the } \\
\text { forest. }\end{array}$ \\
\hline $\begin{array}{l}\text { 然后我死了, } \\
\text { 连羽毛也腐烂在土地里面。 }\end{array}$ & $\begin{array}{l}\text { Then I died, the feathers rot in the ground. } \\
\text { 为什么我的眼里常含泪水, } \\
\text { 因为我对这土地爱得深沉。 }\end{array}$ \\
\hline
\end{tabular}




\subsubsection{Qiao (The Bridge)}

Lu Zaiyi composed this song in 1981 while visiting Wu Jiao County in Jiangsu province where people called it "Shui Xiang" (Water Town). The water towns were found in the central south of China, and they were characterized by the babbling brooks, arched bridges, and old houses by the side. In addition to depicting beautiful water town scenery, the song also expresses a wanderer's strong nostalgia and a deep love of the homeland.$^{95}$ The theme of the song is homesickness. The poem was written by Yu Zhi, an opera librettist who worked at Shanghai Opera House.

Title Translation: The Bridge (桥)

Poet: Yu Zhi (于之, 1927-present)

Range: C4-F5

Tessitura: D4-A4

Tempo: Moderato ad lib.

Difficulty Level: Intermediate level

Voice Type: All voices

Piano accompaniment: short prelude, interlude, and postlude; arpeggio in the prelude and interlude; block chords for the first verse; broken chords for the second verse; limited dynamic ranges; constantly changes of meter; most of the time the top note of the piano part doubles the vocal line or in an octave; triplets; harmonically supporting the voice

Voice characteristics: a short and lovely song; stepwise motion with some small leaps; some appoggiatura; needs excellent sense of legato line.

${ }^{95}$ Tao Guo, “A Discussion of the Artistic Features in Lu Zaiyi's Art Songs” [in Chinese], (Master's Thesis, Shanxi University, 2013), 5. 
Translation

\begin{tabular}{|l|l|}
\hline 桥 & The Bridge \\
\hline 水乡的小桥姿态多, & $\begin{array}{l}\text { There are many small bridges in the water } \\
\text { town. }\end{array}$ \\
\hline 石板缝裡长藤罗。 & $\begin{array}{l}\text { The crevices of the stone bridges are covered } \\
\text { with vines. }\end{array}$ \\
\hline 三步两桥连水港啊, & Three steps, two bridges. \\
\hline 条条玉带映碧波。 & Under the bridges, there are blue waves. \\
\hline 姑娘挑藕桥头歇, & $\begin{array}{l}\text { The girl who carries some lotus root is resting } \\
\text { on the end of the bridge. }\end{array}$ \\
\hline 老汉送粮桥下过。 & $\begin{array}{l}\text { The old man who is crossing under the bridge } \\
\text { is sending the grains to his families. }\end{array}$ \\
\hline 离家千年也恋水乡, & $\begin{array}{l}\text { Even I am away from home thousands of } \\
\text { years, I still love the water town. }\end{array}$ \\
\hline 愿做人间桥一座。 & I want to become a bridge in my hometown. \\
\hline
\end{tabular}




\subsubsection{Zui Hou Yi Ge Meng (The Last Dream)}

The song was composed in 1988. In spite of its simplicity, the text has profound meaning. It expresses people's eagerness to rejoin their families on both sides of the Taiwan Strait. The song was written in the through-composed form (AB). The melodies and rhythms are relatively simple. It has become one of the standard repertoires for voice students in China's conservatories.

Title Translation: The Last Dream (最后一个梦)

Poet: Zhang Hongxi (张鸿西)

Range: Bb3-Eb5

Tessitura: C4-G4

Tempo: Adagio

Difficulty Level: Beginning level

Voice Type: Baritone, mezzo-soprano

Piano accompaniment: block chords; arpeggio; octaves; limited dynamic ranges; harmonically supporting the voice

Voice characteristics: best for a lyrical voice; a short but lovely song; mainly stepwise motion with small leaps; some accidentals; good for beginners. 
Translation

\begin{tabular}{|l|l|}
\hline 最后一个梦 & The Last Dream \\
\hline 做了多少梦, 回回梦相同。 & $\begin{array}{l}\text { How many dreams have I had? I am always } \\
\text { having the same dream. }\end{array}$ \\
\hline 慈母爱游子泪, 骨肉喜相逢。 & $\begin{array}{l}\text { The mom's love, the traveler's tears, they are } \\
\text { happy for reunion. }\end{array}$ \\
\hline 重阳糕端阳粽, 乡土情更浓。 & $\begin{array}{l}\text { I miss my hometown more in Double Ninth } \\
\text { Festival and Dragon Boat Festival. }\end{array}$ \\
\hline 啊啊, 但愿这是最后一个梦。 & Ah, I hope this is my last dream. \\
\hline 做了多少梦, 回回梦相同。 & $\begin{array}{l}\text { How many dreams did I have? I always had } \\
\text { the same dream. }\end{array}$ \\
\hline 姐妹欢兄弟乐, 像光明笑容。 & $\begin{array}{l}\text { My sisters and brothers are laughing. I miss } \\
\text { their bright smile. }\end{array}$ \\
\hline 春风吹兰花摇, 山水情更浓。 & $\begin{array}{l}\text { The spring breeze blows the orchid. Thinking } \\
\text { of my hometown's mountains and rivers } \\
\text { make me feel more homesick. }\end{array}$ \\
\hline 啊啊, 但愿这是最后一个梦。 & Ah, I hope this is the last dream. \\
\hline
\end{tabular}




\subsubsection{Wang Xiang Ci (Musing on My Native Land)}

Yu Youren, a well-known Chinese poet, calligrapher, and educator, authored the poem. As one of the founders of Fu Dan University, Shanghai University, and Northwest ScienceTechnology University of Agriculture and Forestry, he contributed greatly to the development of higher education in China. ${ }^{96}$ In 1949, he moved to Taiwan and spent the rest of his life there. His wife and family, however, were in mainland China. To express his hope of reuniting with his family, he wrote this poem. This poem was set to an art song in 1988 by Lu Zaiyi. The piece was written in the through-composed form and drew elements from southern Chinese folk music.

Title Translation: Musing on My Native Land (望乡词)

Poet: Yu Youren (于右任, 1879-1964)

Range: Bb2-Gb4

Tessitura: Bb3-Eb4

Tempo: Largo

Difficulty Level: Intermediate Level

Voice Type: Baritone

Piano accompaniment: short prelude and interlude; broken chords; triplets; rubato; very wide dynamic ranges; harmonically supporting the voice

Voice characteristics: sweeping and lyrical vocal lines; wide dynamic ranges; triplets; mainly small leaps and stepwise motion; occasionally upward leaps in the interval of fifths.

${ }^{96}$ Xingzhi Ma, “A Discussion of Lu Zaiyi’s Wang Xiang Ci” [in Chinese], Ge Hai, 2011. 


\section{Translation}

\begin{tabular}{|l|l|}
\hline 望乡词 & Musing on My Native Land \\
\hline 葬我于高山之上兮, & Bury me in the mountains, \\
\hline 忘我故乡。 & I wish to see my hometown. \\
\hline 故乡不可见兮, & I can't see it, \\
\hline 永不能忘。 & I can't forget it. \\
\hline 葬我于高山之上兮, & Bury me in the mountains, \\
\hline 望我大陆。 & I wish to see the mainland. \\
\hline 大陆不可见兮, & I can't see it. \\
\hline 只有痛哭。 & I can only cry. \\
\hline 天苍苍野茫茫山之上国有歾。 & $\begin{array}{l}\text { Vast is the sky boundless the wilds. Above } \\
\text { the mountain, lies the pain of my country. }\end{array}$ \\
\hline
\end{tabular}




\subsection{Liu Cong (刘聪)}

Liu Cong (刘聪，1956-present) is a contemporary Chinese composer. He has composed

more than one hundred art songs, thirty-eight of which have won prizes in China's vocal competitions. ${ }^{97}$ These art songs have been used to teach voice in China's schools. His contributions also include his published books on piano accompaniment. A large number of Chinese songs lack piano accompaniment and are only written in numbered musical notation. Liu Cong added piano accompaniment to more than five hundred songs composed by various composers. His book A Guide to Impromptu Piano Accompaniment has been widely used in China's academies. Unlike the art songs from the 1970s and 1980s, with their heavy political influence, Liu's art songs emphasize natural personal feelings. Among his representative works are "Gu Yuan Lian" (Hometown Attachment), "Qiu Feng Zai Shuo" (The Autumn Wind is Murmuring), "Niao Er Zai Feng Zhong Ge Chang" (The Bird is Singing in The Sky), "Xue" (The Snow), "Hai Yu Meng" (The Sea and the Dream), and "Yan Zi" (The Swallow).

\footnotetext{
${ }^{97}$ Pengpeng Lv, “A Discussion of Liu Cong's Art Songs" [in Chinese] (Master's Thesis, Qufu Normal University, 2012), 8.
} 


\subsubsection{Gu Yuan Lian (Love for my Hometown)}

This is the first song from Liu Cong's song cycle Gu Yuan Lian. Shenyang conservatory held a poetry competition in 1994 when Liu worked there, and Du Xuezhi's "Gu Yuan Lian" took the first place. After reading the poem, Liu immediately set it to an art song. Liu worked with Du Xuezhi on the other three songs for the cycle in 1997 and 1998, including "Si Xiang Ye" (The Night of Homesickness), "Gui Xiang" (Going Home), and "Yu Hou" (After the Rain). In the first song, a wanderer leaves his hometown to pursue his dream. He expresses his optimism about the future, and his love for his hometown.

Title Translation: Love for my Hometown(故园恋)

Poet: Du Xuezhi (杜学志)

Range: C4-Bb5

Tessitura: C5-F5

Tempo: Andante

Difficulty Level: Intermediate level

Voice Type: Soprano

Piano accompaniment: short prelude and interlude; broken chords; fast running arpeggio imitating the flowing of the river; triplets; wide dynamic ranges; accidentals; harmonically supporting the voice

Voice characteristics: best for lyrical soprano; include lots of wide upward leaps of fifths, sixths, and octaves; triplets; long sustained note on A5 and F5; wide dynamic ranges. 


\section{Translation}

\begin{tabular}{|c|c|}
\hline 故园恋 & Love for my Hometown \\
\hline $\begin{array}{l}\text { 河水清清, 山道弯弯, } \\
\text { 无名的小镇我的家园, 我的家园。 }\end{array}$ & $\begin{array}{l}\text { The clear water, the mountain roads, the } \\
\text { nameless town, my home. }\end{array}$ \\
\hline 绿草幽幽, 童谣串串。 & The green grass, the childhood songs. \\
\hline 几多欢乐, 几多梦幻。 & $\begin{array}{l}\text { How much wonderful times and good dreams } \\
\text { and memories! }\end{array}$ \\
\hline $\begin{array}{l}\text { 暮歌里走过淡淡的岁月, } \\
\text { 劳作中长大结实的儿男。 }\end{array}$ & $\begin{array}{l}\text { We grew up with the melodies and hard work } \\
\text { in the field. }\end{array}$ \\
\hline $\begin{array}{l}\text { 啊啊 } \\
\text { 小小的山村, 我成长的摇篮。 }\end{array}$ & Ah, this little village, the cradle of my growth. \\
\hline 是你给我生命, & It is you who gives me life. \\
\hline 山一样的性格水一般的心田。 & $\begin{array}{l}\text { Mountain-like character, and water-like heart } \\
\text { field. }\end{array}$ \\
\hline 河水依依, 山道缠绵。 & The clear water, the mountain roads, \\
\hline 终于走出我的家园, 我的家园。 & finally, I walked away from my hometown \\
\hline 友朋嘱托, 父老期盼, & My friends' and my father's kind word, \\
\hline 怎忘故乡声声呼唤。 & $\begin{array}{l}\text { How I could forget the calling from my } \\
\text { hometown. }\end{array}$ \\
\hline $\begin{array}{l}\text { 挥手时涌起冲动的热血, } \\
\text { 憧憬中走进新奇的空间, }\end{array}$ & I enter a new world with longing and joy. \\
\hline $\begin{array}{l}\text { 啊啊, } \\
\text { 小小的山村, 我奋发的起点。 }\end{array}$ & $\begin{array}{l}\text { Ah, little village, my hometown, is the } \\
\text { starting point. }\end{array}$ \\
\hline $\begin{array}{l}\text { 愿你与外面共有同一方沃土, } \\
\text { 同一片蓝天。 }\end{array}$ & $\begin{array}{l}\text { May you share the same fertile soil and the } \\
\text { same blue sky with the outside world. }\end{array}$ \\
\hline
\end{tabular}




\subsubsection{Niao Er Zai Feng Zhong Ge Chang (The Bird is Singing in the Wind)}

The poem is written by Fan Xiaobin, a famous Chinese poet and musician. His representative poems include "Mei Li Xi Bu" (The Beautiful Western Land), "Lan Se Ai Qing Hai" (The Blue Love Sea), and "Xing Fu Shan Ge" (The Joyful Mountain Song). ${ }^{98}$ This poem explores the theme of protection for the environment and bird conservation. ${ }^{99}$ It emphasizes the helplessness of a bird faced with human cruelty from a bird's perspective and voice. Liu Cong wrote this song in 1996 for coloratura sopranos. The song is commonly performed in China's conservatories and competitions.

Title Translation: The Bird is Singing in the Wind (鸟儿在风中歌唱)

Poet: Fan Xiaobin (樊晓斌)

Range: C4-C6

Tessitura: C4-C6

Tempo: Adagio

Difficulty Level: Advanced level

Voice Type: Soprano

Piano accompaniment: Long prelude; triplets; mainly block chords; lots of accidentals; octaves; wide dynamic ranges; harmonically supporting the voice

Voice characteristics: a very challenging song; the last section include lots of coloratura phrases and dynamic changes; two long sustained note on C6; wide upward vocal leaps including fifths, sevenths, and octaves; ending in a sustained note on F5.

${ }^{98}$ Yujing Hou, “A Discussion of Liu Cong's Two Art Songs" [in Chinese], (Master's Thesis, Jiangxi Normal University, 2011), 16.

${ }^{99}$ Ibid, 17. 


\section{Translation}

\begin{tabular}{|l|l|}
\hline 乌儿在风中歌唱 & The Bird is Singing in the Wind \\
\hline 有一只鸟儿盘旋在山岗, & There's a bird hovering in the hills. \\
\hline 它的歌声唱的好凄凉。 & It is singing lonely and desolately. \\
\hline $\begin{array}{l}\text { 不知为什么, 不知为什么, } \\
\text { 它不敢飞进自己的村庄, 自己的村庄。 }\end{array}$ & $\begin{array}{l}\text { I don't know why. It is afraid to fly into its } \\
\text { own village. }\end{array}$ \\
\hline 有一个笼子挂在树上, & There's a cage hanging on the tree, \\
\hline 笼子里关着它的新娘, & Its bride is in the cage. \\
\hline $\begin{array}{l}\text { 它看见猎枪, 它看见猎枪, } \\
\text { 正面对着自己的飞翔, 自己的飞翔。 }\end{array}$ & $\begin{array}{l}\text { It sees the shotgun, right in front of her flying } \\
\text { direction. }\end{array}$ \\
\hline $\begin{array}{l}\text { 鸟儿在风中歌唱, 有谁能理解它的忧伤。 } \\
\text { The bird is singing in the sky, who could } \\
\text { understand its sadness? }\end{array}$ & $\begin{array}{l}\text { Ah! Who could help it? Who could take it } \\
\text { back to his home? }\end{array}$ \\
$\begin{array}{l}\text { 啊啊啊啊 } \\
\text { 回故乡。能把它, 有谁能把它, 有谁能把它带 }\end{array}$ & \begin{tabular}{l} 
back \\
\hline
\end{tabular}
\end{tabular}




\subsection{Wang Luobin (王洛宾)}

Wang Luobin (王洛宾，1913-1996) was a song and opera composer, as well as an

ethnomusicologist. He composed seven operas and over a thousand songs during his lifetime. ${ }^{100}$ He was especially known for rearranging folk songs from northwestern China. Such as "Zai Na Yao Yuan De Di Fang" (From the Distant Place), "Ban Ge Yue Liang Pa Shang Lai" (The Halfmoon is Arising), "Da Ban Cheng De Gu Niang" (The Girl in Daban City), and "Zai Yin Se De Yue Guang Xia" (Under the Silver Moonlight). Songs composed by him can be categorized into three periods. A number of his songs were composed during the Sino-Japanese war to motivate Chinese people in their fight against the invaders, such as "Xi Yi Ge" (The Laundry Song), "Lao Xiang Shang Zhan Chang" (Fellow on the Battlefield), and "Feng Ling Du De Ge Sheng" (The Melody from Feng Ling Du). In his second period, he traveled to Xinjiang province after the PRC's establishment and was captivated by Xinjiang folk songs. He collected and translated Xinjiang folk songs and made significant contributions to the introduction of Xinjiang music to other parts of China. In his later years, Wang traveled to Australia, America, and Singapore many times. Most of his songs from this period reflect the travelers' longing and love for their homeland. ${ }^{101}$ Originally Wang's songs didn't have piano accompaniment. Later composers added piano accompaniment to some of the songs, so they are still being studied and learned in China's conservatories and music schools.

100 Tingting Duan, “A Discussion of the Characteristics and Artistic Value in Wang Luobin's Works” [in Chinese], Mei Li China no.2, 2017, 253.

${ }^{101}$ Ibid, 43. 


\subsection{Lei Zhenbang (雷振邦)}

Known for his film music and song compositions, Lei Zhenbang (雷振邦, 1916-1997)

was a famous Chinese composer. Lei, who had grown up in Beijing in a wealthy family, studied composition in Tokyo from 1939 to 1943 . When Lei returned to China after studying abroad for four years, he began teaching music in middle schools. ${ }^{102}$ His talents were recognized after the establishment of PRC, when he began to work at the Peking Film Studio (now Central News Documentary Film Studio). ${ }^{103} \mathrm{He}$ composed music for seventeen documentaries during this period, which marked the beginning of his film music career. Lei was transferred to Changchun film studio in April of 1955, where his film music composition became more mature and sophisticated. ${ }^{104} \mathrm{He}$ composed songs for seven films between 1956 and 1958. One of the most famous songs from this period was "Hun Shi" (Marriage Vows) from the film Lu Sheng Lian Ge. Its melody and instrumentation are derived from the Lahu Love Song, a folk song of the Lahu ethnic group in Yunnan. ${ }^{105}$ From 1959 to 1965, Lei reached the peak of his composition. Among his most famous compositions for films were Wu Duo Jin Hua (Five Golden Flowers, 1959), Liu San Jie (Third Sister Liu, 1960), and Bin Shan Shang De Lai Ke (Visitors on the Icy Mountain, 1963). These songs have been widely performed in TV shows, competitions, and even at conservatories in China. Throughout Lei's creative career, he traveled all over the country to collect materials. As a musician, he was firmly convinced that life experience was his most

\footnotetext{
102 Aijing Wang, "An Analysis and Performance Guide to Lei Zhenbang's Film Vocal Works" [in Chinese], (Master's Thesis, Zhejiang Normal University, 2016), 6.

${ }^{103}$ Xiaoyi Ma, “Lei Zhenbang's Film Music” [in Chinese], Northern Music, 05/2019, 101.

104 Ibid, 101.

105 Ibid, 101.
} 
important source of inspiration. ${ }^{106}$ His works made a huge contribution to Chinese film and song composition.

${ }^{106}$ Aijing Wang, "An Analysis and Performance Guide to Lei Zhenbang's Film Vocal Works" [in Chinese], (Master's Thesis, Zhejiang Normal University, 2016), 9. 


\subsection{Li Jiefu (李劫夫)}

Li Jiefu (李劫夫，1913-1976) was a famous song composer and music educator during the 20th century. Throughout his career, he composed more than two thousand songs. ${ }^{107}$ As a music educator, he helped establish China's music schools and was the first dean at Shen Yang Conservatory. ${ }^{108} \mathrm{He}$ was also known as the "People's Musician" because his works always reflected the lives of normal people and the fate of his country. Li composed many songs during the Second Sino-Japanese war, including "Wo Men De Tie Qi Bin" (Our Iron Soldier), and "Ge Chang Er Xiao Fang Niu Lang" (A Song for the Cowboy Er Xiao). The songs reflected the resistance of Chinese people against the Japanese. ${ }^{109} \mathrm{Li}$ began composing Chairman Mao Ze Dong's quotations during the Cultural Revolution. He contributed greatly to the popularization of Mao's poems by composing over two hundred songs using Mao's poems. As a "People's Musician," he always wrote songs for normal people. The Xingtai earthquake in Hu Bei province occurred without warning in May 1966. Li went to Xingtai and decided to use songs to encourage the people and contribute to the earthquake relief. ${ }^{110}$ During his thirty-day stay in Xingtai, Li composed thirty-one songs for the people. "Art is a tool to illuminate history and reflect reality. The most valuable quality of art is lost when it is separated from the time when it is made," Li once said. His music speaks to the people, to the country, and to the era.

\footnotetext{
${ }^{107}$ Huan Wei, and Wei wei, "A Discussion about Jiefu's Music" [in Chinese], Journal of Xing Hai Conservatory of Music, no. 3 (2020), 5.

${ }^{108}$ Ibid.

${ }^{109}$ Wenlin Zhou, "Jiefu and his Music" [in Chinese], Yin Yue Cha Zuo, no.6 (2001).

${ }^{110}$ Huan Wei, and Wei wei, "A Discussion about Jiefu's Music" [in Chinese], Journal of Xing Hai Conservatory of Music, no. 3 (2020), 17.
} 


\section{CONCLUSION}

Since the beginning of the 20th century, Chinese art songs have undergone more than a century of development. There have been periods of prosperity and periods of stagnation. Each period has its own characteristics. One special feature of Chinese art songs is that their development is greatly influenced by the Chinese political environment. The political environment often determines the themes of the art songs.

While Chinese art songs are getting more attention, there is still a lack of research on them in comparison to other musical subjects. For a long time, students were more eager to sing arias and folk songs rather than art songs in China's conservatories. In some recitals, more than half of the repertoire were arias. The public also preferred hearing showy arias over art songs. In this case, the study of art songs, especially Chinese art songs were neglected for a long time. The situation changed at the beginning of the 21 st century when the current dean of Shanghai Conservatory of Music Liao Changyong and Chinese bass baritone Shen Yang began to sing, study, and record Chinese art songs, which brought some charming Chinese art songs to the public. The works of numerous composers, such as Huang Zi, Xian Xinghai, Zhao Yuanren, Xiao Youmei, Qing Zhu, and He Lvting, were promoted and performed widely in China's Conservatories. Music academies and various vocal competitions have begun to value Chinese art songs. Now the audiences hear more of this repertoire in recitals.

One study can't possibly cover the entire scope of Chinese art songs after 1950. The twelve composers I have presented in this research are the ones who are the most well-known to the public. Their works are often studied and performed in China's music academies. However, there are a number of other accomplished composers such as Tie Yuan, Jin Xiang, Luo

Zongxian, Tian Guang, Tao Siyao, etc. They also wrote beautiful art songs. Their works are less 
known to the general public and therefore performed less in recitals. Further study is needed on these composers and their works. 


\section{APPENDIX I: LIST OF THE ART SONGS IN ALPHABETIC ORDER}

\begin{tabular}{|c|c|c|c|}
\hline Title & Title in Chinese & Title in English & Page Number \\
\hline A La Mu Han & 阿拉木汗 & A La Mu Han & $30-31$ \\
\hline $\begin{array}{l}\text { Ai Ren Song Wo } \\
\text { Xiang Ri Kui }\end{array}$ & 爱人送我向日葵 & $\begin{array}{l}\text { My Lover Sent Me } \\
\text { Sunflowers }\end{array}$ & $23-24$ \\
\hline $\begin{array}{l}\text { Ba Li Sheng Mu } \\
\text { Yuan De Qiao Zhong } \\
\text { Ren }\end{array}$ & $\begin{array}{l}\text { 巴黎圣母院的敲钟 } \\
\text { 人 }\end{array}$ & $\begin{array}{l}\text { The Bellringer at } \\
\text { Notre-Dame de Paris }\end{array}$ & $69-70$ \\
\hline $\begin{array}{l}\text { Cai Yun Yu Xian } \\
\text { Hua }\end{array}$ & 彩云与鲜花 & $\begin{array}{l}\text { The Colorful Clouds } \\
\text { and Flowers }\end{array}$ & 93-94 \\
\hline $\begin{array}{l}\text { Chun Feng Yuan Wu } \\
\mathrm{Qu}\end{array}$ & $\begin{array}{l}\text { 春风圆舞曲 } \\
\end{array}$ & The Spring Ballade & $71-72$ \\
\hline Chun Xiao & 春晓 & A Spring Morning & $34-35$ \\
\hline $\begin{array}{l}\text { Chun-Zu Guo De } \\
\text { Chun Tian }\end{array}$ & 春-祖国的春天 & $\begin{array}{l}\text { Spring-My Country's } \\
\text { Spring }\end{array}$ & $82-83$ \\
\hline Deng Guan Que Lou & 登鹤雀楼 & On the Stork Tower & $38-39$ \\
\hline Duo Qing De Tu Di & 多情的土地 & The Amorous Land & $53-54$ \\
\hline E Mei Shan Yue Ge & 峨眉山月歌 & $\begin{array}{l}\text { Song for the Moon } \\
\text { over Mountain E Mei }\end{array}$ & $48-49$ \\
\hline Feng Qiao Ye Bo & 枫桥夜泊 & $\begin{array}{l}\text { Mooring at Night by } \\
\text { the Maple Bridge }\end{array}$ & $36-37$ \\
\hline Ga O Li Tai & 嘎哦丽泰 & Ga O Li Tai & $28-29$ \\
\hline Gu Yuan Lian & 故园恋 & $\begin{array}{l}\text { Love for my } \\
\text { Hometown }\end{array}$ & 104-105 \\
\hline Huang Hun & 黄昏 & The Evening & $50-51$ \\
\hline Huai Hua Ji Shi Kai & 槐花几时开 & $\begin{array}{l}\text { When the Sophora } \\
\text { Will Blossom }\end{array}$ & $21-22$ \\
\hline $\begin{array}{l}\text { Huo Ba Jie De Huo } \\
\text { Ba }\end{array}$ & 火把节的火把 & The Torch Festival & $67-68$ \\
\hline $\begin{array}{l}\text { Ke Ai De Yi Duo } \\
\text { Mei Gui Hua }\end{array}$ & 可爱的一朵玫瑰花 & A Lovely Rose & $17-18$ \\
\hline Lan Hua Yu Hu Die & 兰花与蝴蝶 & Orchid and Butterfly & $43-44$ \\
\hline $\begin{array}{l}\text { Lao Shi, Wo Zong } \\
\text { Shi Xiang Qi Ni }\end{array}$ & $\begin{array}{l}\text { 老师, 我总是想起 } \\
\text { 你 }\end{array}$ & $\begin{array}{l}\text { My Teacher, I } \\
\text { Always Miss You }\end{array}$ & $79-80$ \\
\hline $\mathrm{Ma} \mathrm{Yi} \mathrm{La}$ & 玛依拉 & Ma Yi La & $19-20$ \\
\hline
\end{tabular}




\begin{tabular}{|c|c|c|c|}
\hline $\mathrm{Mu} \mathrm{Di}$ & 牧笛 & The Reed Pipe & 73-74 \\
\hline Na Jiu Shi Wo & 那就是我 & That I am & $41-42$ \\
\hline $\begin{array}{l}\text { Niao Er Zai Feng } \\
\text { Zhong Ge Chang }\end{array}$ & 鸟儿在风中歌唱 & $\begin{array}{l}\text { The Bird is Singing } \\
\text { in the Wind }\end{array}$ & 106-107 \\
\hline Qi Yue De Cao Yuan & 七月的草原 & The Grassland in July & $75-76$ \\
\hline Qiao & 桥 & The Bridge & $97-98$ \\
\hline $\begin{array}{l}\text { Qiu-Pa Mi Er, Wo De } \\
\text { Jia Xiang Duo Me } \\
\text { Mei }\end{array}$ & $\begin{array}{l}\text { 秋-帕米尔, 我的家 } \\
\text { 乡多么美 }\end{array}$ & $\begin{array}{l}\text { Autumn-Pamirs, how } \\
\text { Beautiful My } \\
\text { Hometown is }\end{array}$ & $84-85$ \\
\hline $\begin{array}{l}\text { She Jiang Cai Fu } \\
\text { Rong }\end{array}$ & 涉江采芙蓉 & $\begin{array}{l}\text { Crossing the River to } \\
\text { pick Hibiscus }\end{array}$ & $46-47$ \\
\hline Shui Ku Ye Ge & 水库夜歌 & $\begin{array}{l}\text { A Night Melody in } \\
\text { the Reservoir }\end{array}$ & $55-56$ \\
\hline $\begin{array}{l}\text { Tai Yang Chu Lai Xi } \\
\text { Yang Yang }\end{array}$ & 太阳出来喜洋洋 & $\begin{array}{l}\text { The Rise of the Sun } \\
\text { brings us Hope and } \\
\text { Happiness }\end{array}$ & $15-16$ \\
\hline $\begin{array}{l}\text { Tu Lu Fan De Pu Tao } \\
\text { Shu Le }\end{array}$ & 吐鲁番的葡萄熟了 & $\begin{array}{l}\text { Turpan's Grapes are } \\
\text { Ripe }\end{array}$ & $64-65$ \\
\hline Wo Ai Mei Yuan Mei & 我爱梅园梅 & $\begin{array}{l}\text { The Lovely } \\
\text { Wintersweet in Mei } \\
\text { Garden }\end{array}$ & $86-87$ \\
\hline $\begin{array}{l}\text { Wo Ai Ni, Zhong } \\
\text { Guo }\end{array}$ & 我爱你, 中国 & $\begin{array}{l}\text { I Love My Country, } \\
\text { China }\end{array}$ & $88-89$ \\
\hline Wo Ai Zhe Tu Di & 我爱这土地 & I Love this Land & $95-96$ \\
\hline Wang Xiang Ci & 望乡词 & $\begin{array}{l}\text { Musing on My } \\
\text { Native Land }\end{array}$ & 101-102 \\
\hline $\begin{array}{l}\text { Wo De Zu Guo Ma } \\
\text { Ma }\end{array}$ & 我的祖国妈妈 & $\begin{array}{l}\text { My Home Country, } \\
\text { My Ma Ma }\end{array}$ & $62-63$ \\
\hline Xiao He Tang Shui & 小河淌水 & The Flowing River & $26-27$ \\
\hline $\begin{array}{l}\text { Zai Yin Se De Yue } \\
\text { Guang Xia }\end{array}$ & 在银色的月光下 & Under the Moonlight & $32-33$ \\
\hline $\begin{array}{l}\text { Zai Xi Wang De Tian } \\
\text { Ye Shang }\end{array}$ & 在希望的田野上 & $\begin{array}{l}\text { On the Fields of } \\
\text { Hope }\end{array}$ & $57-58$ \\
\hline Zhu Jiu Ge & 祝酒歌 & A Drinking Song & $59-61$ \\
\hline $\begin{array}{l}\text { Zu Guo-Ci Xiang De } \\
\text { Mu Qin }\end{array}$ & 祖国, 慈祥的母亲 & $\begin{array}{l}\text { My Country, My } \\
\text { Kind Mom }\end{array}$ & $91-92$ \\
\hline $\begin{array}{l}\text { Zu Guo Yong Zai Wo } \\
\text { Xin Zhong }\end{array}$ & 祖国永在我心中 & $\begin{array}{l}\text { My Country is } \\
\text { Always in My Heart }\end{array}$ & $77-78$ \\
\hline
\end{tabular}


\begin{tabular}{|l|l|l|l}
\hline Zui Hou Yi Ge Meng & 最后一个梦 & The Last Dream & 99-100
\end{tabular} 


\section{BIBLIOGRAPHY}

\section{Books}

Kuo, Chang-yang. Chinese Art Song: A Melodic Analysis. Yang Ming Shan: Hwa Kang Press, 1972.

Li, Mingshu, and Ning Ping. A Survey of Chinese Art Song. [in Chinese]. Shanghai: Shanghai Music Publishing House, 2009.

Mo, Jigang. Chinese Art Song Performance Guide. [in Chinese]. Shanghai: Shanghai Music Publishing House, 2003.

Schoppa, R. Keith. Twentieth Century China: A History in Documents. Oxford: Oxford University Press, 2010.

Yang Mimi, Jie Zheng and Lipin Zhao. A Guide of Chinese Art Song. [in Chinese]. Shanghai: Shanghai Educational Publication House, 2009.

Zhang Xiaonong, History of Chinese Vocal Music. [in Chinese]. Shanghai Music Publishing House, 2015.

\section{Thesis/Dissertations}

Chang, Tingting. “"“A Survey of Selected Classical Chinese Art Songs for Solo Voice and Piano.” DMA diss., West Virginia University, 2020. ProQuest (28071684).

Chi, MeiFeng Kang. "A Performance Guide for Contemporary Chinese Art Songs from Taiwan.” EdD diss., Teachers College, Columbia University,1996. ProQuest (AAT 9635963).

Guo, Tao. “A Discussion of the Artistic Features in Lu Zaiyi’s Art Songs.” [in Chinese]. Master's Thesis, Shanxi University, 2013.

Hallis, Xiang Chen. "Chinese art song from 1912 to 1949.” DMA diss., The University of Texas at Austin, 1995. ProQuest (AAT 9617398).

Hou, Yujing. “A Discussion of Liu Cong's Two Art Songs.” [in Chinese]. Master's Thesis, Jiangxi Normal University, 2011.

Li, Meng. "The Characteristics and Performance Guide to Lu Zaiyi’s Art Songs." [in Chinese]. Master's Thesis, Shandong Normal University, 2014.

Li, Yanming. "The Analysis of the Creative Features and Performance in Shang Deyi's Art Songs.” [in Chinese]. Master's Thesis, North Minzu University, 2017. 
Li, Xiaofeng. “An Analysis of Shi Guangnan's Works for Voice.” [in Chinese]. Master's Thesis, Shanxi University, 2012.

Liao, Xiaolin. “A Survey of Ding Shande's Art Songs.” [in Chinese]. Master's Thesis, Hunan Normal University, 2007.

Lv, Pengpeng. "A Discussion of Liu Cong's Art Songs." [in Chinese]. Master's Thesis, Qufu Normal University, 2012.

Ma, Yixing. "A Discussion of Zheng Qiufeng's Art Songs.” [in Chinese]. Master's Thesis, Nanjing Art School, 2009.

Sun, Xinming. "A Discussion of the Development and Features of Chinese Art Song." Master's Thesis, Guangxi University, 2015.

Wang, Aijing. "An Analysis and Performance Guide to Lei Zhenbang's Film Vocal Works." [in Chinese]. Master's Thesis, Zhejiang Normal University, 2016.

Wang, Ran. "An Analysis of the Artistic Characteristics and Performance Guides to Chun Xiao." [in Chinese]. Master's Thesis, Sichuan Normal University, 2018.

Wu, Fangqin. "A Discussion and Performance Guide to Shang Deyi's Three Epochal Art Songs." [in Chinese]. Master's Thesis, Sichuan Normal University, 2013.

Wu, Meng. "A Discussion of the Music Characteristics in Shi Guangnan's Art Songs-Zhu Jiu Ge as a Case Study." [in Chinese]. Master's Thesis, Xi An Conservatory, 2014.

Wu, Taotao. "Songs in Poetry-Exploring the Characteristics in Li Haiying's Art Songs." [in Chinese]. Master's Thesis, Hebei Normal University, 2014.

Xin, Yancun. "A Research of the Melodic Techniques in Lu Zaiyi's Art Songs." [in Chinese]. Master's Thesis, Zhejiang Normal University, 2015.

Zhao, Xiaoxiao. “A Discussion of Zheng Qiufeng's Art Songs.” [in Chinese]. Master's Thesis, Guangxi Normal University, 2015.

\section{Articles}

Cheung, H. Y. Joys. "Singing Ancient Piety and Modernity in 'Song of Familial Bliss' (1935): Musical Translation of Huang Zi (1904-1938) in Interwar China." Asian Music Vol. 41, No.2 (Summer/Fall 2010): 4-58.

Dou, Zhi. "A Discussion of the Development of Chinese Contemporary Art Song." Da Zhong Wen Yi, (August 2012): 37-38. 
Duan, Tingting. "A Discussion of the Characteristics and Artistic Value in Wang Luobin's Works.” [in Chinese]. Mei Li Zhong Guo, no.2 (2017): 253.

Guan, yue, and Rong, jingjin. "A Survey of Gu Jianfen's Songs." [in Chinese]. Bei Fang Yin Yue, no.06 (2020): 7-8.

Ju, Qihong. "A Poet with Love-Lu Zaiyi and his Vocal Composition.” [in Chinese]. People's Music, no.11 (2004): 4-8.

Jue, Yuanjing. "The Development and Characteristics of Chinese Art Song after the Establishment of the People's Republic of China.” Modern Music, no. 2 (2020): 148-149.

Li Juanji. "Study on Luo Zhongrong's Chinese Poetry Art Songs: A Case Study of Zhegutian." [in Chinese]. Journal of Huaihai Institute of Technology (Humanities \&. Social Sciences Edition) Vol. 14, no. 9 (September 2016): 66-71.

Liang, Maochun. "A Survey of Art Song During Cultural Revolution.” [in Chinese]. Journal of the Central Conservatory, no.1 (2008): 32-34.

Lin, Mu. "The discussion about the nature of the wusi movement." [in Chinese]. Zhexue yanjiu 2, (1963): 77-79.

Liu, Yanfang. "A Discussion of Shang Deyi’s Art Song Ba Li Sheng Mu Yuan De Qiao Zhong Ren." [in Chinese]. Qilu Realm of Arts, no.4 (2010): 81-83.

Ma, Xiaoyi. “Lei Zhenbang's Film Music.” [in Chinese]. Northern Music, (May 2019): 245-253.

Ma, Xingzhi. “A Discussion of Lu Zaiyi’s Wang Xiang Ci.” [in Chinese]. Ge Hai, (March 2011).

Ni, Duanlin. "The Creation of Ding Shangde's Art Songs." [in Chinese]. Journal of Shang Hai Conservatory, no.4 (2005): 9-22.

Wang, Ningyi. “A Discussion of Luo Zhongrong's She Jiang Cai Fu Rong.” [in Chinese]. Music Research, no.4 (1981): 41-45.

Wei, Huan, and Wei, wei. “A Discussion about Jiefu's Music.” [in Chinese]. Journal of Xing Hai Conservatory of Music, no. 3 (July 2020): 5-24.

Wei, Ziting. "A discussion of the artistic features in classical poetry." [in Chinese]. Modern Music, no. 3 (2017): 81.

Xi, Xinxin. "An Analysis of the Characteristics and Performance in Qiu, Pamir, Wo De Jia Xiang Duo Me Mei." [in Chinese]. Appreciation, (2018): 87. 
Xiao, Yong. "An Analysis of the third Song from Zu Guo Si Ji-Qiu, Pamir, Wo de Jia Xiang Duo Me Mei." [in Chinese]. Art Communication, (March 2003).

Ya, Wen. “The Warrior, The Singer-Zheng Qiufeng and His Works.” [in Chinese]. People's Music, (September 1980): 29-32.

Yang, Liu. "A Comparative Study of E Mei Shan Yue Ge-Luo Zhongrong's version and Zhao Jipin's version as Examples.” [in Chinese]. Northern Music, (2008): 106-107.

Zhang, Huiqin, and Deng, Chenglei. "Feng Qiao Ye Bo Sung by Tenor.” [in Chinese]. Huang He Zhi Sheng, no.24 (2019): 48-51.

Zhang, Xianguang. "An Analysis and Performance Guide to Duo Qing De Tu Di." Xi Ju Zhi Jia, (December 2018): 82.

Zhang, Yang, “The Folk Tunes used in Shi Guangnan's Art Songs.” [in Chinese]. Mei Li Zhong Guo, no.101 (January 2010): 4-8.

Zhou, Wenlin. "Jiefu and his Music.” [in Chinese]. Yin Yue Cha Zuo, no.6 (2011): 49-50.

Zhou, Yang. "A Discussion of the Music Characteristics in Zai Xi Wang De Tian Ye Shang." [in Chinese]. Huang He Zhi Sheng, no.6 (2013): 86-87.

Zhou, Yuchen. "An Analysis of the Artistic Features in the Song Collection 'Zhan Di Xin Ge' during Cultural Revolution.” [in Chinese]. Huang He Zhi Sheng, no. 17 (2020): 44-45.

Zhou, Yuzhu. "Performance Guidance to Shang Deyi's art song Chun Feng Yuan Wu Qu." [in Chinese]. Yin Yue Shi Kong, (May 15th, 2012): 46-47.

\section{Anthologies}

Lu, Zaiyi. I Love This Land: Lu Zai Yi's Art Songs. Shanghai: Shanghai Music Publishing House, 2005.

Shang, Deyi. A New Collection of Shang Deyi's Art Songs. Beijing: Central Conservatory of Music Press, 2008.

Zhang, Chou, and Kuanping Mao. The Anthology of Chinese Art Songs. Shanghai: Shanghai Educational Publishing House, 2007.

Zhong, Mei eds. Traditional and Modern Chinese Art Songs. New York: Leyerle Publications, 2009.

Zhong, Mei eds. Contemporary Chinese art songs. Book 1. Fayetteville, AR: Classical Vocal Reprints, 2018. 
Zhong, Mei eds. Contemporary Chinese art songs. Book 2. Fayetteville, AR: Classical Vocal Reprints, 2019.

Zhou, Zhenxi, and Chuanwen Pei eds. A Collection of Chinese Art Songs (1978-1995). Beijing: People's Music Publisher, 2003. 